\title{
Dietary macronutrients and food consumption as determinants of long-term weight change in adult populations: a systematic literature review
}

\author{
Mikael Fogelholm*, Sigmund Anderssen², \\ Ingibjörg Gunnarsdottir ${ }^{3}$ and Marjaana Lahti-Koski ${ }^{4}$
}

\footnotetext{
'Department of Food and Environmental Sciences, University of Helsinki, Helsinki, Finland; ' ${ }^{2}$ Department of Sports Medicine, Norwegian School of Sport Sciences, Oslo, Norway; ${ }^{3}$ Faculty of Food Science and Nutrition, University of Iceland, Reykjavik, Iceland; ${ }^{4}$ Finnish Heart Association, Helsinki, Finland
}

\begin{abstract}
This systematic literature review examined the role of dietary macronutrient composition, food consumption and dietary patterns in predicting weight or waist circumference (WC) change, with and without prior weight reduction. The literature search covered year 2000 and onwards. Prospective cohort studies, case-control studies and interventions were included. The studies had adult (18-70 y), mostly Caucasian participants. Out of a total of 1,517 abstracts, 119 full papers were identified as potentially relevant. After a careful scrutiny, 50 papers were quality graded as A (highest), B or C. Forty-three papers with grading A or B were included in evidence grading, which was done separately for all exposure-outcome combinations. The grade of evidence was classified as convincing, probable, suggestive or no conclusion. We found probable evidence for high intake of dietary fibre and nuts predicting less weight gain, and for high intake of meat in predicting more weight gain. Suggestive evidence was found for a protective role against increasing weight from whole grains, cereal fibre, high-fat dairy products and high scores in an index describing a prudent dietary pattern. Likewise, there was suggestive evidence for both fibre and fruit intake in protection against larger increases in WC. Also suggestive evidence was found for high intake of refined grains, and sweets and desserts in predicting more weight gain, and for refined (white) bread and high energy density in predicting larger increases in WC. The results suggested that the proportion of macronutrients in the diet was not important in predicting changes in weight or WC. In contrast, plenty of fibre-rich foods and dairy products, and less refined grains, meat and sugar-rich foods and drinks were associated with less weight gain in prospective cohort studies. The results on the role of dietary macronutrient composition in prevention of weight regain (after prior weight loss) were inconclusive.
\end{abstract}

Keywords: obesity; weight gain; weight maintenance; diet; fat; carbohydrates; protein; nutrition

Received: 13 March 2012; Revised: 2 June 2012; Accepted: 29 June 2012; Published: 13 August 2012

$\mathrm{T}$ he prevalence of obesity has increased globally during the past $30 \mathrm{y}$ (1). According to the WHO statistics, $35 \%$ of adults aged $20 \mathrm{y}$ and older were overweight (BMI $\geq 25 \mathrm{~kg} / \mathrm{m}^{2}$ ) in 2008 (2). The worldwide prevalence of obesity has nearly doubled between 1980 and 2008. Moreover, WHO has estimated that worldwide 2.8 million people die each year as a result of being overweight or obese, and an estimated 35.8 million (2.3\%) of global disability-adjusted life-years are caused by overweight or obesity. A recent European study concluded that in a worst-case scenario almost every third European adult might be obese by year 2015 (3).

The total food supply has increased during the last decades (4). When compared against the secular trends in obesity, an increase in food supply and a concomitant increase in total energy intake are likely to be one of the 
major drivers in the obesity epidemic (1). However, the role of dietary macronutrient composition, intake of specific food items or dietary patterns in development of obesity is not clear.

During the last decade, a few narrative reviews have addressed the role of diet in prevention of weight gain (5-7). Systematic reviews and meta-analyses have focused on specific issues, like the role of sugar-sweetened beverages (8-10). The results have been inconclusive. Moreover, we are not aware of any recent (last $5 \mathrm{y}$ ) and broad systematic reviews examining the associations of dietary macronutrients, food intake and dietary patterns vs. change in weight or waist circumference (WC) in adult populations. These data are needed to, e.g. give supporting evidence in formulating new nutrition recommendations. The present work was done in connection to the 2012 Nordic Nutrition Recommendations. The purpose of this systematic literature review was to examine the associations of dietary macronutrient composition, food consumption and dietary patterns in prevention of weight or WC gain, with and without prior weight reduction.

\section{Methods}

\section{Research questions and definitions}

The research questions were formulated separately for studies on primary prevention of weight gain and for studies addressing weight regain after prior weight reduction.

(1) Primary prevention of obesity (maintenance of body weight and/or WC):

What is the effect of different dietary macronutrient composition on long-term ( $\geq 1 \mathrm{y}$ ) change in weight/WC/body fat in an adult population?

(2) Prevention of weight regain after weight loss (or maintenance of reduced body weight):

What is the effect of different dietary macronutrient composition on long-term ( $\geq 1 \mathrm{y}$ ) change in weight/WC/body fat in individuals who have deliberately reduced their weight by at least $5 \%$ ?

In the search, dietary macronutrient composition was defined as containing:

(1) carbohydrates, fat and protein as \% in energy intake

(2) fat quality in diet: variation in saturated (SFA), monounsaturated (MUFA) or polyunsaturated (PUFA) fatty acids, as \% in energy intake or g/day

(3) sugar intake as g/day or \% in energy intake

(4) fibre (fiber) intake as $\mathrm{g} / \mathrm{day}$
Several of the papers selected for the review contained data on food consumption or dietary patterns. Consequently, the review was expanded to include different food items and food groups, such as cereal products, whole-grain cereals, fruit, vegetables, milk and milk products, meat, etc. Moreover, we also included studies using a whole-diet approach, such as the Mediterranean diet or an index for healthy eating (according to existing dietary recommendations).

The search terms are shown in Appendix 1. The databases used were PubMed and SweMed/SweMed + (the latter was used to identify Nordic articles not published in PubMed).

\section{Inclusion criteria}

The a priori defined inclusion criteria were as follows: Publication year

- year 2000 and later

Study type

- Cross-sectional: excluded

- Follow-up (cohort): included but minimum follow-up 1 y

- Case-control: included

- Weight-maintenance interventions: included with the following criteria: (1) intentional mean weight loss at least 5\%; (2) at least 6 months follow-up. The followup (after weight reduction) could be non-randomised (observational cohort study) or a randomised intervention. In the latter case, the randomisation was done after weight loss, in the beginning of the weightmaintenance intervention. A further premise was that weight reduction was similar in different weightmaintenance groups. Weight loss interventions were also accepted if the total duration was longer than $3 \mathrm{y}$.

Age

- Inclusion criteria: adult. Age range 18-70 y.

- Exclusion: studies with $>70$ y participants only and those in which results were not separately analysed by age (i.e. $>70$ y participants in their own group)

Race/geographical location

- Studies without Caucasians or with Caucasians as minority group were excluded

\section{Selection and evaluation of papers}

The abstracts after the initial search were screened by two of the authors (Sigmund Anderssen and Ingibjörg Gunnarsdottir). All articles suggested by at least one of the two were ordered as full papers. The two other authors (Mikael Fogelholm and Marjaana Lahti-Koski) 
then screened the full papers. Again, papers suggested by at least one of them were at least preliminary included in the quality assessment (most careful scrutiny) and evaluation table. Also reviews were ordered as full papers. However, they were not eventually included in the quality grading, because of too much variation in, for example, inclusion criteria, years covered and age groups included.

The quality assessment of the papers was done according to the principles of the Nordic Nutrition Recommendation 2012 working group (11). In short, all papers were evaluated according to a three-scale grading: $\mathrm{A}=$ high quality studies with very low level of potential bias; $\mathrm{B}=$ some bias, but not enough to invalidate the results; $\mathrm{C}=$ significant bias and weaknesses that may invalidate the results. The preliminary quality assessments and construction of summary tables were done individually (Marjaana Lahti-Koski: macronutrients and weight change; SA and IG: food consumption and weight change, dietary patterns and weight change; MF: weight change after weight reduction), but the final product was crosschecked together by all authors.

After the quality grading, four summary tables (macronutrients, food consumption, dietary patterns and weight change after weight reduction) were formed from all studies quality graded A or B. In these tables, the results were arranged according to exposure and outcome variables. However, we did not separate unadjusted and adjusted (to BMI) WC. We always chose the model with most adjustments as the statistical outcome. Moreover, we used analyses with sexes combined, if possible. Otherwise the results of men and women are presented separately. We did not use any other stratification variables, such as prior weight change or smoking.

The grading of evidence was based on the summary tables and a four-class grading: convincing (high), probable (moderate), suggestive (low) and no conclusion (insufficient). The minimum requirement for 'suggestive' was two studies showing an association, and no conflicting results. If some studies showed ns (neither positive nor negative association), it was decided that for 'suggestive evidence', the number of results showing an association was required to be at least two higher than those showing no association.

\section{Results}

A total of 1,517 abstracts were initially screened for eligibility (Fig. 1). Out of these, 119 were selected and ordered as full papers. A total of 50 papers were quality graded (12-61). These include 41 papers identified through the original literature search and nine additional papers $(17,30,31,32,36,45,47,51,55)$ found from the reference lists of the other publications or 'related citations' in PubMed. The reasons for excluding 78 full papers $(5,8-10,62-135)$ are shown in Appendix 2. The number of studies with data on body composition was

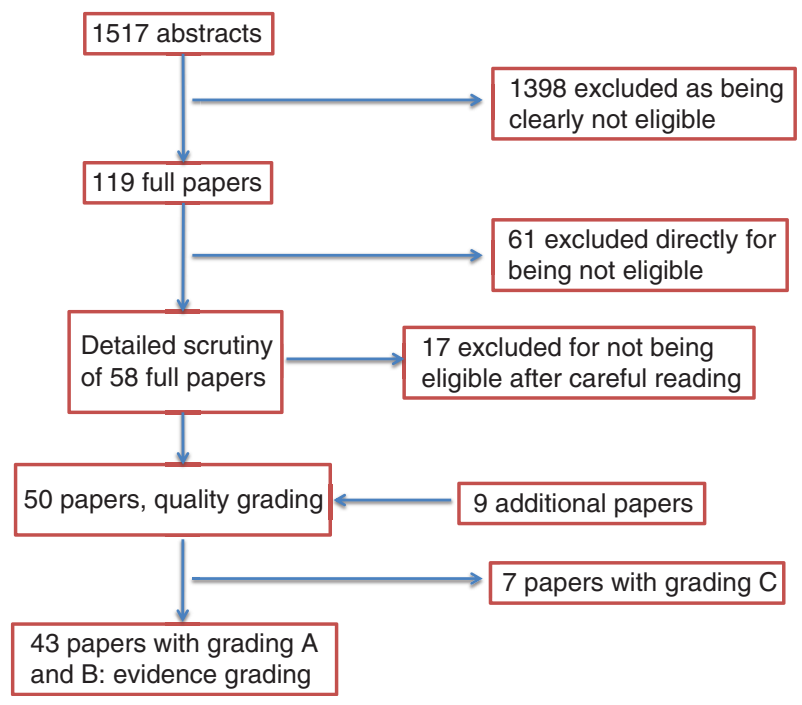

Fig. 1. Flow-chart of the systematic literature review process.

low and therefore our analyses are based only on weight (BMI) and WC.

The evidence tables (Appendix 3-6) present all studies with quality assessment. Studies on the association between macronutrients and weight change are presented in Appendix 3. Studies using energy density as an exposure were also included here. Studies on food contsumption and weight change are presented in Appendix 4. Studies using glycaemic index (GI) or glycaemic load (GL) as the main exposure variable are also shown here. Appendix 5 presents the studies on dietary patterns and weight change, and Appendix 6 shows studies on weight change after prior weight reduction (studies on weight regain). The results are summarised for the grading of evidence in Tables 1-4 (in the text).

\section{Macronutrients and change in weight or WC}

Most of the studies used for the grading of evidence for the association between macronutrient intake and weight change were prospective cohort studies (Table 1 and Appendix 3). The spread of exposures against the two optional outcomes (change in weight or WC) was large, and most exposure-outcome combinations were assessed by only one or two studies. This leads inevitably to difficulties in finding any evidence for associations between macronutrient intakes and weight change.

The evidence linking high fibre intake to prevention of weight gain was considered probable. In addition, three suggestive associations were found, for cereal fibre against weight change, and for fibre and energy density against change in WC. Five studies assessed weight gain in relation to fibre intake. The association was negative (high fibre intake indicated smaller weight gain) in three studies $(14,18,21,26)$, while one (19) did not find an association. A similar, albeit slightly weaker conclusion was obtained 
Table 1. Summary of studies on the association between dietary macronutrients and weight change (see Appendix 1).

\begin{tabular}{|c|c|c|c|c|c|c|c|c|}
\hline \multirow[b]{2}{*}{ Exposure } & \multirow[b]{2}{*}{ Outcome variable } & \multirow[b]{2}{*}{ No. of participants } & \multicolumn{3}{|c|}{ Reported associations } & \multirow[b]{2}{*}{ Number of studies rated as $A$ or $B^{\prime}$} & \multirow[b]{2}{*}{ Strength of evidence } & \multirow[b]{2}{*}{ References } \\
\hline & & & + & ns & - & & & \\
\hline Carbohydrates & Weight & 39,275 & & 2 & & $A: I, B: I$ & No conclusion & 17,19 \\
\hline $\mathrm{CHO}$ from foods with simple sugars & WC & 44,817 & IW & IM & B: I & B: I & No conclusion & 17 \\
\hline $\mathrm{CHO}$ from fruit and vegetables & WC & 44,817 & & IM & IW & B: I & No conclusion & 17 \\
\hline $\mathrm{CHO}$ from potatoes & WC & 44,817 & IW & IM & & B: I & No conclusion & 17 \\
\hline $\mathrm{CHO}$ from refined grains & WC & 44,817 & IW & IM & & B: I & No conclusion & 17 \\
\hline Fibre & Weight & 270,307 & & I & 4 & $A: 3, B: 2$ & Probable & $14,18,19,21,26$ \\
\hline Fibre & WC & 106,019 & & IM & $\begin{array}{l}\text { I } \\
\text { IW } \\
\text { IM }\end{array}$ & B: 3 & Suggestive & $14,20,23$ \\
\hline Fruit fibre & Weight & 27,082 & & & IM & B: I & No conclusion & 35 \\
\hline Cereal fibre & Weight & $116,5 \mid 4$ & & & $\begin{array}{l}\text { I } \\
\text { IM }\end{array}$ & B: 2 & Suggestive & 14,35 \\
\hline Protein & Weight & 49,277 & & I & & $A: I$ & No conclusion & 19 \\
\hline Protein & WC & 44,817 & & & I & B: I & No conclusion & 17 \\
\hline Fat & Weight & $257,99 \mid$ & $\begin{array}{l}\mathrm{I} \\
2 \mathrm{~W}\end{array}$ & $\begin{array}{l}3 \\
\text { IM }\end{array}$ & & A: $2, B: 4$ & No conclusion & $16-19,25,42$ \\
\hline Fat & WC & 44,817 & I & & & B: I & No conclusion & 17 \\
\hline SFA & Weight & 130,950 & IW & I & & B: 2 & No conclusion & 15,16 \\
\hline SFA & WC & 89,432 & & I & & B: I & No conclusion & 16 \\
\hline MUFA & Weight & 130,950 & & I & IW & B: 2 & No conclusion & 15,16 \\
\hline MUFA & WC & 89,432 & & I & & B: I & No conclusion & 16 \\
\hline PUFA & Weight & 130,950 & IW & I & & B: 2 & No conclusion & 15,16 \\
\hline PUFA & WC & 89,432 & & I & & B: I & No conclusion & 16 \\
\hline TFA & Weight & 41,518 & IW & & & B: I & No conclusion & 15 \\
\hline TFA substituted for $\mathrm{CHO}$ & WC & 16,587 & IM & & & B: I & No conclusion & 20 \\
\hline TFA substituted for PUFA & WC & 16,587 & IM & & & B: I & No conclusion & 20 \\
\hline Vegetable fat & WC & 44,817 & IW & & & B: I & No conclusion & 17 \\
\hline Energy density & Weight & 141,220 & IW & 2 & & A: I, B: 2 & No conclusion & $12,13,19$ \\
\hline Energy density & WC & 138,063 & 2 & & & B: 2 & Suggestive & 13,23 \\
\hline
\end{tabular}

CHO, carbohydrates; SFA, saturated fatty acids; PUFA, polyunsaturated fatty-acids; TFA, trans fatty acids; W, waist circumference; M, men; W, women; +, associated with increased weight gain; ns, no association with weight change; -, associated with decreased weight gain (prevention of weight gain).

'Some studies included several analyses (e.g. separately for men and women). Therefore, the number of results may be greater than the number of studies. 
for cereal fibre $(14,35)$. Also studies analysing the association between fruit fibre against weight change (35), or the association between total fibre and change in WC $(14,23)$, tended to favour a protective role of fibre intake.

The other suggestive evidence on the role of dietary macronutrients in development of obesity was observed for energy density (total energy intake divided by the weight of food consumed) against change in WC: both identified studies $(13,23)$ reported that higher energy density was associated with larger increase in WC. The results on energy density against weight change were less consistent. Bes-Rastrollo et al. (12) reported that an increase in energy density was associated with a simultaneous increase in weight, while two other studies $(13,19)$ did not find an association.

The intake of total carbohydrates, fats and proteins did not show consistent associations with weight gain. Especially in the case of fat intake vs. weight change, the number of studies (four) was in fact relatively high, but the results were quite evenly dispersed between a positive association (higher fat intake would increase weight gain) $(25,42)$ and no significant association $(16,17)$. Similarly, the results on intake of SFA or PUFA against development of obesity indicated either a positive (15) or no significant association (16). Field et al. (15) linked MUFA with protection of weight gain, but this finding was not confirmed in the study of Forouhi et al. (16). Koh-Banerhee et al. (20) investigated the role of transfatty acids (TFA): their results suggested that TFA, when substituted for carbohydrates or PUFA, are associated with increased WC. Also Field et al. (15) found a positive association between TFA intake and weight gain. Hence, all three analyses showed that high intake of TFA predicts weight gain. The lack of multiple data on specific combinations prevents us from making a stronger conclusion.

Howard et al. reported that higher intake of total carbohydrates protected against weight gain in women (18), but Halkjaer et al. (17) did not find an association between carbohydrate intake and change in weight or WC. The source of carbohydrates may be relevant, however, since Halkjaer et al. (17) reported a positive association between carbohydrates from foods with simple sugars, from potatoes and from refined grains, against change in WC in women. In contrast, they also found that high carbohydrates intake from vegetables (women only) and fruit protected against an increase in WC.

The role of protein in prevention of an increase in weight or WC was inconsistent: the two identified studies reported a neutral (19) or negative (17) association.

\section{Foods and change in weight or WC}

Compared with the association between macronutrients and weight change, a few more 'suggestive' associations were found (Table 2 and Appendix 4). According to the data, high intake of whole grains, fruit, nuts and high-fat dairy protect against increasing obesity, whereas refined grains, white bread, meat and sweets and desserts seem to promote gains in weight or WC. Unfortunately, even here the main challenge in making broader conclusions was that the number of studies for a specific combination of exposure and outcome was limited (rarely more than two data points).

The suggestive association linking high intake of whole grains to lower weight gain was based on two cohort studies $(35,36)$. No other studies in this combination of exposure and outcome were found. However, Halkjaer et al. (32) did not find an association between the intake of wholegrain bread and change in WC. Two studies (33, 39) reported that a high intake of fruit predicted smaller increase in WC, with no conflicting results. On the other hand, studies linking fruit to changes in weight were not equally consistent $(36,45)$.

Three studies reported a negative association between intake of nuts and change in weight $(30,36,60)$, and no conflicting data were found. The evidence was regarded as probable. Unfortunately, these studies are not fully independent, since two of them are partly or totally based on data from the Nurses' Health Study $(30,36)$.

Several studies have investigated the role of dairy products in prevention of weight gain. Again, the definition of exposure variable was inconsistent (dairy in general, high-fat dairy, low-fat dairy, etc.) and this left only a few relevant combinations for assessment in this review. Both studies examining the relationship between high-fat dairy and weight gain reported a negative association, that is, higher intake of these dairy products was associated with smaller gains in weight $(38,50)$. Also some other studies found a protective role for dairy products $(33,36,39,41)$, while others did not report any significant associations between dairy intake and change in weight or WC $(32,38)$. There were no studies with a positive association between any kind of dairy products and change in weight or WC.

The intake of refined bread was associated with an increase in WC in both studies identified for this review $(32,39)$. A similar supporting evidence was observed for the positive association between refined grain and weight change $(21,36)$

Three studies reported a positive association between meat intake and weight change $(40,44,50)$ and this evidence was regarded as probable. The studies of Rosell et al. (40) and Vergnaud et al. (44) are not, however, totally independent: the former was based on a subpopulation of the EPIC-cohort, while the latter used the entire cohort for analyses. Some other studies also linked higher intake of meat, poultry or processed meat with an increase in weight or $\mathrm{WC}(33,36,39)$. No association were reported by a few $(28,32,33)$, whereas Halkjaer et al. (33) 
Table 2. Summary of studies on the association between food consumption and weight change (see Appendix 2).

\begin{tabular}{|c|c|c|c|c|c|c|c|c|}
\hline \multirow[b]{2}{*}{ Exposure } & \multirow{2}{*}{$\begin{array}{l}\text { Outcome } \\
\text { variable }\end{array}$} & \multirow[b]{2}{*}{ No of participants } & \multicolumn{3}{|c|}{ Reported associations } & \multirow{2}{*}{$\begin{array}{l}\text { Number of studies } \\
\text { rated as } A \text { or } B^{1}\end{array}$} & \multirow{2}{*}{$\begin{array}{l}\text { Strength of } \\
\text { evidence }\end{array}$} & \multirow[b]{2}{*}{ References } \\
\hline & & & + & ns & - & & & \\
\hline Breakfast cereals & Risk of obesity & $|7,88|$ & & & IM & B: I & No conclusion & 27 \\
\hline Whole grains & Weight & 147,959 & & & $\begin{array}{l}\mathrm{I} \\
\mathrm{IM}\end{array}$ & B: 2 & Suggestive & 35,36 \\
\hline Wholegrain bread & WC & 2,436 & & 1 & & B: I & No conclusion & 32 \\
\hline Refined grains & Weight & 194,968 & 2 & & & B: 2 & Suggestive & 21,36 \\
\hline Refined (white) bread & WC & 51,067 & 2 & & & B: 2 & Suggestive & 32,39 \\
\hline Fruit & Weight & 494,680 & & 1 & $\mathrm{I}$ & B: 2 & No conclusion & 36,45 \\
\hline Fruit & WC & 91,327 & & & 2 & B: I & Suggestive & 33,39 \\
\hline Fruit and vegetables & WC & 2,436 & & 1 & & B: I & No conclusion & 32 \\
\hline Vegetables & Weight & 494,680 & & 1 & 1 & B: 2 & No conclusion & 36,45 \\
\hline Vegetables & WC & 91,327 & & IM & I & B: 2 & No conclusion & 33,39 \\
\hline Potato chips & Weight & 120,877 & 1 & & & B: I & No conclusion & 36 \\
\hline Potatoes & Weight & 120,877 & I & & & B: I & No conclusion & 36 \\
\hline Potatoes & WC & 93,763 & $\begin{array}{l}\text { I } \\
\text { IW }\end{array}$ & $\begin{array}{l}1 \\
\text { IM }\end{array}$ & & B: 2 & No conclusion & $32,33,39$ \\
\hline Nut consumption & Weight & 180,930 & & & $\begin{array}{l}2 \\
\mathrm{IW}\end{array}$ & B: 3 & Probable & $30,36,60$ \\
\hline Olive oil & Weight & 7,368 & & 1 & & B: I & No conclusion & 29 \\
\hline Butter & Weight & 120,877 & 1 & & & B: I & No conclusion & 36 \\
\hline Butter and/or margarine & WC & 93,763 & 1 & I & IW & B: 3 & No conclusion & $32,33,39$ \\
\hline Dairy, general & Weight & 42,856 & & IM & IW & B: 2 & No conclusion & 38,41 \\
\hline Dairy, general & WC & 48,631 & & & 1 & B: I & No conclusion & 39 \\
\hline Dairy, high-fat & WC & 42,696 & & IM & IW & B: I & No conclusion & 33 \\
\hline Dairy, high-fat/whole-fat & Weight & 29,823 & & & $\begin{array}{l}\mathrm{I} \\
\mathrm{IM}\end{array}$ & B: 2 & Suggestive & 38,50 \\
\hline Dairy, low-fat dairy & Weight & 23,504 & & I & & B: I & No conclusion & 38 \\
\hline Dairy, milk and cheese & WC & 2,436 & & 1 & & B: I & No conclusion & 32 \\
\hline Dairy, yoghurt & Weight & 120,877 & & & 1 & B: I & No conclusion & 36 \\
\hline Meat, general & Weight & 380,122 & 3 & & & B: 3 & Probable & $40,44,50$ \\
\hline Meat, poultry & WC & 42,696 & IW & IM & & B: I & No conclusion & 33 \\
\hline Meat, processed meat & Weight & 120,877 & I & & & B: I & No conclusion & 36 \\
\hline Meat, processed meat & WC & 91,327 & $\begin{array}{l}\text { I } \\
\text { IW }\end{array}$ & IM & & B: 2 & No conclusion & 33,39 \\
\hline $\begin{array}{l}\text { Meat, red (unprocessed) } \\
\text { meat }\end{array}$ & Weight & $|28,07|$ & 1 & 1 & & B: 2 & No conclusion & 28,36 \\
\hline Meat, red meat & WC & 45,132 & & 1 & 1 & B: 2 & No conclusion & 32,33 \\
\hline $\begin{array}{l}\text { Hamburgers, pizza and } \\
\text { sausages }\end{array}$ & Weight & 7,194 & 1 & & & & No conclusion & 28 \\
\hline Fish & WC & 2,436 & & 1 & & B: I & No conclusion & 32 \\
\hline SSSD & Weight & 58,797 & IW & 1 & & B: 2 & No conclusion & 28,43 \\
\hline SSSD & WC & 48,631 & I & & & B: I & No conclusion & 39 \\
\hline Sweetened fruit juice & Weight & 7,194 & & 1 & & B: I & No conclusion & 28 \\
\hline Sweets and desserts & Weight & 138,246 & 2 & & & B: 2 & Suggestive & 36,42 \\
\hline Sugar and confectionary & WC & 48,632 & I & & & B: I & No conclusion & 39 \\
\hline Cakes and chocolate & WC & 2,436 & & 1 & & B: I & No conclusion & 32 \\
\hline Sauce & Weight & 17,369 & IW & IM & & B: I & No conclusion & 42 \\
\hline Snack foods & WC & 42,696 & $\mathrm{I}$ & & & B: I & No conclusion & 33 \\
\hline $\mathrm{Gl}$ & Weight & 89,808 & IW & 1 & & B: 2 & No conclusion & 31,34 \\
\hline
\end{tabular}




\begin{tabular}{|c|c|c|c|c|c|c|c|c|}
\hline \multirow[b]{2}{*}{ Exposure } & \multirow{2}{*}{$\begin{array}{l}\text { Outcome } \\
\text { variable }\end{array}$} & \multirow[b]{2}{*}{ No of participants } & \multicolumn{3}{|c|}{ Reported associations } & \multirow{2}{*}{$\begin{array}{l}\text { Number of studies } \\
\text { rated as } A \text { or } B^{\prime}\end{array}$} & \multirow{2}{*}{$\begin{array}{l}\text { Strength of } \\
\text { evidence }\end{array}$} & \multirow[b]{2}{*}{ References } \\
\hline & & & + & ns & - & & & \\
\hline & & & & IM & & & & \\
\hline $\mathrm{Gl}$ & WC & 49,007 & I, IW & IM & & B: 2 & No conclusion & 23,34 \\
\hline GL & Weight & 89,808 & I & I & & B: 2 & No conclusion & 31,34 \\
\hline \multirow[t]{2}{*}{ GL } & WC & 49,383 & IW & I & & B: 2 & No conclusion & 23,34 \\
\hline & & & & IM & & & & \\
\hline
\end{tabular}

WC, waist circumference; M, men; W, women; GI, glycaemic index; GL, glycaemic load; SSSD, sugar-sweetened soft drink; +, associated with increased weight gain; ns, no association with weight change; -, associated with decreased weight gain (prevention of weight gain).

'Some studies included several analyses (e.g. separately for men and women). Therefore, the number of results may be greater than the number of studies.

found that higher intake of red meat protected against an increase in WC, adjusted for BMI.

Two studies reported that a high intake of sweets and desserts, was associated with larger weight increases (36, 42). This association could be classified as suggestive. Two studies found a positive association between intake of sugar-sweetened soft drinks (SSSD) and weight or WC gain $(39,43)$, while such as association was not confirmed in a third study (28). However, there were no studies suggesting an inverse association of sugar-rich foods and change in weight or WC.

The few results linking GI or GL to changes in weight or WC were dispersed between a positive $(23,31,34)$ and no association $(23,34)$. It may be worth noting that a positive association between GI/GL vs. change in weight or WC was more often observed in women than in men $(23,34)$.

\section{Dietary patterns and weight change}

We identified five studies with results on the relationship between dietary patterns and weight change (Table 3 and Appendix 5). Three of these used an index of the Mediterranean diet $(47,49,50)$ and two others the American Diet Quality Index $(48,51)$. The index for Mediterranean diet is based on the consumption of 'positive' (e.g. fruit, vegetables, legumes, whole grains, fish, olive oil) and 'negative' (e.g. meat and dairy) food items. The Diet Quality Index is based on US dietary recommendations: it is a measure of how well an individual meets the recommendations for SFA, cholesterol, sodium, total fat and total carbohydrate.

Both studies using the Diet Quality Index reported that meeting the recommendations was associated with less weight gain during the follow-up $(48,51)$. The evidence is suggestive. Two studies with the Mediterranean index supported this conclusion $(47,49)$, while the third study did not find an association between Mediterranean dietary patterns and weight change after all statistical adjustments (50).

\section{Macronutrients and prevention of weight regain after weight loss}

Only nine studies were identified with data on the association between dietary macronutrient composition and weight gain after prior weight reduction (Table 4 and Appendix 6). All six studies classified as A or B were randomised weight-maintenance interventions. Delbridge et al. (59) prescribed a weight-maintenance diet with energy intake corresponding to $1.3 \times$ estimated resting energy expenditure, but all other studies used ad lib energy intake throughout the weight-maintenance phase. Overall, the results were inconclusive and it was not possible to make any conclusions.

A high-protein, low-carbohydrate diet protected against weight regain in on study (55), but no effects were observed in three other studies $(52,53,59)$. Due et al. (54) found that both a high-fat, low-carbohydrate, and a low-fat, high-carbohydrate diet reduced weight regain,

Table 3. Summary of studies on the association between dietary patterns and weight change (see Appendix 3).

\begin{tabular}{|c|c|c|c|c|c|c|c|c|}
\hline \multirow[b]{2}{*}{ Exposure } & \multirow[b]{2}{*}{ Outcome variable } & \multirow[b]{2}{*}{ No of participants } & \multicolumn{3}{|c|}{ Reported associations } & \multirow{2}{*}{$\begin{array}{c}\text { Number of studies } \\
\text { rated as } A \text { or } B\end{array}$} & \multirow{2}{*}{$\begin{array}{l}\text { Strength of } \\
\text { evidence }\end{array}$} & \multirow[b]{2}{*}{ References } \\
\hline & & & + & ns & - & & & \\
\hline Mediterranean diet index & Weight & 390,498 & & I & 2 & B: 3 & No conclusion & $47,49,50$ \\
\hline Healthy/prudent diet index & Weight & 7,158 & & & 2 & A: I, B: I & Suggestive & 48,51 \\
\hline
\end{tabular}

+ , Associated with increased weight gain; ns, no association with weight change; -, associated with decreased weight gain (prevention of weight gain). 
Table 4. Summary of studies on the association between weight-maintenance interventions (prevention of weight regain) and weight change (see Appendix 4).

\begin{tabular}{|c|c|c|c|c|c|c|c|c|}
\hline \multirow[b]{2}{*}{ Exposure } & \multirow[b]{2}{*}{ Outcome variable } & \multirow[b]{2}{*}{ No of participants } & \multicolumn{3}{|c|}{ Reported associations } & \multirow{2}{*}{$\begin{array}{c}\text { Number of studies } \\
\text { rated as A or B }\end{array}$} & \multirow{2}{*}{$\begin{array}{l}\text { Strength of } \\
\text { evidence }\end{array}$} & \multirow[b]{2}{*}{ References } \\
\hline & & & + & ns & - & & & \\
\hline HP/LC (vs. LP/HC) & Weight & 120 & & 2 & & B: 2 & No conclusion & 52,59 \\
\hline HP/LC (vs. CON) & Weight & 973 & & IW & I & A: I, B: I & No conclusion & 53,55 \\
\hline HF/LC (vs. CON) & Weight & 77 & & & I & $A: I$ & No conclusion & 54 \\
\hline HF/LC (vs. LF/HC) & Weight & 99 & & & I & $A: I$ & No conclusion & 54 \\
\hline LF/HC (vs. CON) & Weight & 175 & I & 1 & & A: I, B: I & No conclusion & 54,57 \\
\hline Low GI vs. high GI & Weight & 773 & & & I & A: I & No conclusion & 55 \\
\hline
\end{tabular}

$\mathrm{H}$, high; L, low; P, protein; F, fat; C, carbohydrate; CON, control -according to nutrition recommendations; GI, glycaemic index; M, men; W, women; +, associated with increased weight gain; ns, no association with weight change; -, associated with decreased weight gain (prevention of weight gain).

when compared against a control diet with 'normal' macronutrient composition. Also in the study of Swinburn et al. (57), a low-fat, high-carbohydrate protected against weight regain at $2-y$ follow-up, but this effect was lost 2 y later.

Finally, Larsen et al. (55) found that a diet with low GI prevented weight regain, when compared against a high GI diet. This effect was observed regardless of the macronutrient composition. However, the most effective combination in terms of prevention of weight regain after weight reduction was high-protein, low-carbohydrate diet with low GI.

\section{Discussion}

\section{Interpretation of results}

The main findings of this systematic review on nutrients and foods in relation to weight change were the following: we found probable evidence for high intake of dietary fibre and nuts predicting less weight gain, and for high intake of meat in predicting more weight gain. Suggestive evidence was found for a protective role against increasing weight from whole grains, cereal fibre, high-fat dairy products and high scores in an index describing a prudent dietary pattern. Likewise, there was suggestive evidence for both fibre and fruit intake in protection against larger increases in WC. Also suggestive evidence was found for high intake of refined grains, and sweets and desserts in predicting more weight gain, and for refined (white) bread and high energy density in predicting larger increases in WC.

A major problem in assessing the grade of evidence was that similar combinations of exposure and outcome variables were eventually quite rare. Therefore, we decided to do a post hoc evidence analysis by first combining the outcome variables. Although WC, compared with BMI, may be a slightly stronger risk factor for cardiovascular diseases, Type 2 diabetes and breast and colorectal cancers, they both can be used as a measure of obesity in population studies almost interchangeably (136, 137). Moreover, to get more studies into one evidence grading, we grouped foods by their closeness of nutrient composition. The results of these post hoc analyses are shown in Table 5. Since we may violate the strict rules of evidence grading by subjectively combining different exposure variables, this analysis is 'unofficial' and the grading of evidence is not shown in the table.

We combined studies with fibre, vegetables, fruit, fruit fibre, carbohydrates from fruit \& vegetables, whole grains, whole grain bread or nuts as an exposure variable into one group called 'fibre-rich foods'. Some studies included several analyses, either separately for men and women, or for different exposure and/or outcome variables. Hence, the identified 14 studies included a total of 28 analyses. Out of these, 21 results (13 with both sexes, 4 with only women and 4 with only men) indicated that a higher intake of at least one of these 'fibre-rich foods' is associated with prevention of obesity. Eight analyses did not find a significant association. In this light, the evidence for a protective role of fibre-rich foods in general might be considered moderately strong.

The use of fibre-rich products reduce dietary energy density by increasing the volume of food without bringing additional absorbable energy (12). Fruit and vegetables have a low GI, whereas fibre-rich bread may induce a lowered insulin response and delayed glucose decline (138). Both properties could increase satiety and reduce energy consumption (139). In addition, other biologically active compounds in fruit, vegetables and whole grain (e.g. phenolic compounds and phytoestrogens) may be related to weight control (35).

Nuts may be regarded as a 'special case' among fibrerich products, not least because of their high fat content. Nevertheless, even earlier epidemiological evidence suggests an inverse association between nut consumption and body weight (140). The proposed mechanisms include increased energy expenditure due to high protein and 
Table 5. Post hoc analyses: evidence for association between grouped exposure variables (taken from summary Tables 1 and 2) against grouped outcome variables (BMI and waist circumference not separated).

\begin{tabular}{|c|c|c|c|c|c|c|}
\hline \multirow[b]{2}{*}{ Group name } & \multirow[b]{2}{*}{ Exposure variables } & \multicolumn{3}{|c|}{ Effect } & \multirow[b]{2}{*}{ No of studies' } & \multirow[b]{2}{*}{ References } \\
\hline & & + & ns & - & & \\
\hline Fibre-rich foods & $\begin{array}{l}\text { Fibre, vegetables, fruit, fruit fibre, } \\
\text { carbohydrates from fruit and vegetables, } \\
\text { whole grains, whole grain bread, nuts }\end{array}$ & & $\begin{array}{l}5 \\
3 M\end{array}$ & $\begin{array}{l}13 \\
4 W \\
4 M\end{array}$ & 14 & $\begin{array}{l}|4,| 7-2 \mid, 23,26,30 \\
35,36,39,45,60\end{array}$ \\
\hline Refined grains & $\begin{array}{l}\text { Refined grains, carbohydrates from } \\
\text { refined grains, refined bread }\end{array}$ & 5 & & & 4 & $17,21,36,39$ \\
\hline Potatoes & Potatoes, carbohydrates from potatoes & I & $\begin{array}{l}\text { I } \\
\text { IM }\end{array}$ & & 3 & $17,32,36$ \\
\hline Dairy & $\begin{array}{l}\text { Dairy general, high-fat dairy, low-fat } \\
\text { dairy, milk and cheese, yoghurt }\end{array}$ & & $\begin{array}{l}2 \\
2 M\end{array}$ & $\begin{array}{l}3 \\
2 W \\
I M\end{array}$ & 5 & $36,38,39,41,50$ \\
\hline Meat & $\begin{array}{l}\text { Meat general, poultry, processed meat } \\
\text { unprocessed or red meat }\end{array}$ & $\begin{array}{l}6 \\
2 W\end{array}$ & $\begin{array}{l}2 \\
2 M\end{array}$ & I & 8 & $\begin{array}{l}28,32,33,36,39,40, \\
44,50\end{array}$ \\
\hline Healthy diet & $\begin{array}{l}\text { Index of Mediterranean diet, index of } \\
\text { healthy/prudent diet }\end{array}$ & & 1 & 4 & 5 & $47-51$ \\
\hline
\end{tabular}

M, men; W, women; +, associated with increased weight gain; ns, no association with weight change; -, associated with decreased weight gain (prevention of weight gain).

'Some studies included several analyses, either separately for men and women, or for different exposure and/or outcome variables. Therefore, the number of results may be greater than the number of studies.

unsaturated fatty-acid content, enhanced satiety and ineffective absorption of fat (140). Short-term interventions have not shown any effects of nuts on body weight, whereas nut consumption seems to improve blood lipid levels in a dose-related manner (141).

Refined grains, carbohydrates from refined grains and refined bread formed a group called 'refined grain foods'. Four studies included five analyses, and all of them showed an association between high intake of refined grains and increasing obesity. The level of evidence could be regarded as probable, but slightly weaker than the evidence seen for fibre-rich foods. Refined grain products have often high GI, high insulin response and a fast glucose decline even below baseline in an oral test (138). These properties could increase hunger and enhance lipogenesis, thereby promoting obesity (142). The different effects of whole-grain and refined cereals speak for separating different types of cereals in the food pyramid.

Also potatoes have high GI, and therefore it could be plausible to think that they - like refined grains - could induce obesity. The results of our review were not very convincing: two analyses supported the above hypothesis, while two other did not find an association between potato consumption and weight or WC change. It is possible that the way potatoes are prepared is important: Mozaffarian et al. (36) reported a positive association between potato consumption and weight gain, but in this study a majority of the potatoes was French fries.
All dairy products were combined to form a new group called 'dairy foods'. In our 'official' analyses, we found suggestive evidence for a protecting role of highfat dairy foods. The combined data did not strengthen this result. A total of four analyses showed a positive association between dairy food consumption and increasing obesity, whereas five analyses did not report any associations. If there indeed is an association between dairy products and prevention of weight gain, the proposed mechanisms might be related to calcium, protein or biopeptides (143). More research is needed to find out whether the mechanism could be related to milk fat. Earlier studies have, in contrast, indicated that unsaturated, rather than saturated, fatty acids may promote postprandial fat oxidation and stimulate dietinduced thermogenesis (144). The two studies showing an association between high-fat dairy and less weight gain $(38,50)$ did not very clearly specify their definition of dairy products, e.g. if only milk products were included. However, butter was apparently not included in either study.

A majority of the studies support the hypothesis that a high consumption of meat and meat products predict more weight gain. This finding might be considered confusing, because of the proposed satiating effects of protein (145). However, meat is energy dense and might thereby increase energy intake (44). It is also possible that meat intake only reflects some undetected dietary or lifestyle patterns that contribute to weight gain (44). 
Yet another possibility is that meat increases fat-free mass and that BMI in this case would be misleading. Interestingly, the two studies showing a preventive role for protein or meat used WC as the outcome $(17,33)$. On the other hand, two studies identified poultry or processed meat as a predictor of larger gains in $\mathrm{WC}(33,39)$.

We found suggestive evidence for an obesity-promoting role of sweets and desserts. Since the contribution of sweets to total energy intake is small (146), a likely explanation for this finding is residual confounding, that is, consumption of sweets probably mirror some other unhealthy dietary and/or physical activity patterns that lead to positive energy balance. In fact, we were rather expecting to find an association between the use of SSSD and weight gain. Out of the identified three studies, two suggested that SSSD predict weight or WC gain $(39,43)$, but the third (28) found an association only in a subgroup with prior weight gain. Hence, according to our strict rules we had to classify these data as inconclusive. Recent systematic reviews have also produced conflicting results on the association between SSSD and weight gain (8-10). A majority of the results suggesting a positive association between SSSD and weight gain have studied children and adolescents $(8,9)$. The compilation of different sugarcontaining foods into one analysis did not bring any additional insights.

It is perhaps not a surprise that adherence to a presumed healthy diet predicts less weight gain. It is interesting that the Healthy Diet Index is in fact composed of items without any clear association with weight (total fat, saturated fat, dietary cholesterol, salt, carbohydrates) - and yet a diet fulfilling these requirements is at the same time suitable for weight control. The Mediterranean Diet Index is built from foods and many of the 'positive' foods are high in dietary fibre and these foods have in this review been identified as predictors of better weight control. Moreover, meat is considered a 'negative' item in the Mediterranean Diet Index and we found suggestive evidence for meat as a predictor for weight gain. The only discrepancy is related to dairy products which are 'negative' in the Mediterranean Diet Index, but, if anything, protective against weight gain in our review.

Methodological considerations

The criteria for A-grading were very strict. Because of the understandable crudeness of epidemiological methods, all really large studies (e.g. EPIC, Nurses' Health Study, etc.) were classified as B, while some clearly smaller studies sometimes received an A-rating. In the end, this did not have an impact on the analyses, since all studies classified as A or B were included in the summary tables.

Most of the studies identified for this review were prospective cohort designs. Although interventions would be much stronger in identifying causal effects, the possibility to study long-term (5-20 y) weight changes by using an intervention design would be extremely challenging and expensive. All prospective cohort studies need careful control for potential confounders. Although practically all A- and B-graded cohorts in our review were able to control for a multiple of potential confounding variables, residual confounding cannot be ruled out (147). Therefore, it is unclear whether the identified positive or negative associations really are effects of nutrients or foods vs. weight or WC.

One interesting point is whether energy intake should be included in the model. While adjusting for total energy intake may control for over- and under-reporting, energy intake is also a potential mechanism explaining the association between a nutrient/food and weight gain. Therefore, adjusting for energy intake might be regarded as overadjustment, which may dilute the real association between food/nutrient and weight change. For future studies, it would be recommendable to present models with energy intake as the only differing variable (to see if the inclusion of energy intake in the model has an effect on the results). We did not look for a potential association between total energy intake and weight change, since a positive energy balance is too much dependent on the level of total physical activity and energy expenditure. A scrutiny on the interaction between physical activity and diet, against weight change, was also outside the focus of this review.

Measurements of dietary intake and food consumption at baseline are usually inaccurate. Most of the population studies covered in this review used a food frequency questionnaire (FFQ). Although many of the FFQ's have been validated (see Appendix 3-5), the validation was often restricted to certain nutrients. For instance, we are not aware of a FFQ planned to assess GI or dietary density. In addition to inaccurate baseline estimation, an individual's dietary pattern may change during the followup. These lead to misclassifications of exposure and to at least some attenuation of association towards unity (type II error). In this light it is interesting to note that there were very few totally conflicting findings (same exposure showing both negative and positive association with the outcome). If some of the non-significant findings were indeed type II errors, there may be in reality more associations between diet and weight change than found in the present review.

Another point - which is in a way opposite to the previous - is that the large number of participants in several studies allows identification of even very small differences between groups (e.g. lowest vs. highest $25 \%$ ). The practical significance of these differences is uncertain. Most studies have assessed the association between single nutrients and food items against weight change, but aggregating single foods into composite scores yields more robust estimations $(36,39)$. By combining exposure 
variables (foods) into larger groups, as shown in Table 5, we wanted to improve the robustness of our analysis. To be meaningful, however, even these results should probably be translated into diet-level recommendations.

Many cohorts were initiated more than $10 \mathrm{y}$ ago. This is perhaps not very meaningful for analyses using foods, food groups or dietary patterns. However, since a certain macronutrient composition can be achieved by different food choices, the interpretation of the oldest studies should be done with care: for instance, a certain proportion of carbohydrates and fat in a diet in 1980s might be related to different food choices than a similar macronutrient distribution in 2012. This may also have a relevance to the association between macronutrients and weight gain. Finally, it may relevant to repeat that the review covered publication years 2000-2012, and this may have excluded important older studies. Moreover, although PubMed is a very comprehensive database and it covers all major international medical journals, it is possible that some additional studies could have been identified by using, e.g. EMBASE or Scopus. The potential bias caused by using only PubMed and SweMed +is, however, considered negligible.

\section{Conclusion}

In this systematic review covering publications from year 2000 onwards, we found probable evidence for high intake of dietary fibre and nuts predicting less weight gain, and for high intake of meat in predicting more weight gain. Suggestive evidence was found for a protective role against increasing weight from whole grains, cereal fibre, high-fat dairy products and high scores in an index describing a prudent dietary pattern. Likewise, there was suggestive evidence for both fibre and fruit intake in protection against larger increases in WC. Also suggestive evidence was found for high intake of refined grains, and sweets and desserts in predicting more weight gain, and for refined (white) bread and high energy density in predicting larger increases in WC. When foods with similar nutrient composition were combined for an unofficial analysis, fibre-rich foods in general predicted less weight gain and this association could be regarded as moderately strong (probably). The associations between foods and dietary patterns vs. weight gain were stronger compared to those between macronutrients vs. weight gain. In general, the results suggest that the proportion of macronutrients in the diet is not important in prevention of obesity. In contrast, plenty of fibre-rich foods and dairy products, and less refined grains, meat and sugar-rich foods and drinks were associated with less weight gain in prospective cohort studies.

\section{Conflict of interest and funding}

The review is part of the NNR 2012 project, with financial support from the Nordic Council of Ministers.

\section{References}

1. Swinburn BA, Sacks G, Hall KD, McPherson K, Finegood DT, Moodie ML, et al. The global obesity pandemic: shaped by global drivers and local environments. Lancet 2011; 378: 804-14.

2. World Health Organization. WHO Global Status Report 2010. Geneva: World Health Organization.; 2011.

3. von Ruesten A, Steffen A, Floegel A, van der A DL, Masala G, Tjønneland A, et al. Trend in obesity prevalence in European adult cohort populations during follow-up since 1996 and their predictions to 2015. PLoS ONE 2011; 6: e27455.

4. Kearney J. Food consumption trends and drivers. Philos Trans R Soc Lond B Biol Sci 2010; 365: 2793-807.

5. Astrup A. The role of dietary fat in the prevention and treatment of obesity. Efficacy and safety of low-fat diets. Int J Obes Relat Metab Disord 2001; 25(Suppl 1): S46-50.

6. van Dam RM, Seidell JC. Carbohydrate intake and obesity. Eur J Clin Nutr 2007; 61(Suppl 1): S75-99.

7. Du H, Feskens E. Dietary determinants of obesity. Acta Cardiol 2010; 65: 377-86.

8. Gibson S. Sugar-sweetened soft drinks and obesity: a systematic review of the evidence from observational studies and interventions. Nutr Res Rev 2008; 21: 134-47.

9. Malik VS, Schulze MB, Hu FB. Intake of sugar-sweetened beverages and weight gain: a systematic review. Am J Clin Nutr 2006; 84: 274-88.

10. Forshee RA, Storey ML, Allison DB, Glinsmann WH, Hein GL, Lineback DR, et al. A critical examination of the evidence relating high fructose corn syrup and weight gain. Crit Rev Food Sci Nutr 2007; 47: 561-82.

11. NNR5 working group. A guide for conducting systematic literature reviews for the 5 th edition of the Nordic Nutrition Recommendations. http://www.slv.se/upload/NNR5/A\%20guide\% 20for $\% 20$ conducting $\% 20$ SLR $\% 20$ for $\% 20$ NNR $5 \% 20$ FINAL.pdf. [cited 1 Aug 2012].

12. Bes-Rastrollo M, van Dam RM, Martinez-Gonzalez MA, Li TY, Sampson LL, Hu FB. Prospective study of dietary energy density and weight gain in women. Am J Clin Nutr 2008; 88: 769-77.

13. Du H, van der A DL, Ginder V, Jebb SA, Forouhi NG, Wareham NJ, et al. Dietary energy density in relation to subsequent changes of weight and waist circumference in European men and women. PLoS ONE 2009; 4: e5339.

14. Du H, van der A DL, Boshuizen HC, Forouhi NG, Wareham NJ, Halkjaer J, et al. Dietary fiber and subsequent changes in body weight and waist circumference in European men and women. Am J Clin Nutr 2010; 91: 329-36.

15. Field AE, Willett WC, Lissner L, Colditz GA. Dietary fat and weight gain among women in the Nurses' Health Study. Obesity (Silver Spring) 2007; 15: 967-76.

16. Forouhi NG, Sharp SJ, Du H, van der A DL, Halkjaer J, Schulze MB, et al. Dietary fat intake and subsequent weight change in adults: results from the European Prospective Investigation into Cancer and Nutrition cohorts. Am J Clin Nutr 2009; 90: 1632-41.

17. Halkjaer J, Tjønneland A, Thomsen BL, Overvad K, Sørensen TIA. Intake of macronutrients as predictors of 5-y changes in waist circumference. Am J Clin Nutr 2006; 84: 789-97.

18. Howard BV, Manson JE, Stefanick ML, Beresford SA, Frank $\mathrm{G}$, Jones B, et al. Low-fat dietary pattern and weight change over 7 years: the Women's Health Initiative Dietary Modification Trial. JAMA 2006; 295: 39-49.

19. Iqbal SI, Helge JW, Heitmann BL. Do energy density and dietary fiber influence subsequent 5-year weight changes 
in adult men and women? Obesity (Silver Spring) 2006; 14: $106-14$.

20. Koh-Banerjee P, Chu N-F, Spiegelman D, Rosner B, Colditz G, Willett W, et al. Prospective study of the association of changes in dietary intake, physical activity, alcohol consumption, and smoking with 9-y gain in waist circumference among 16587 US men. Am J Clin Nutr 2003; 78: 719-27.

21. Liu S, Willett WC, Manson JE, Hu FB, Rosner B, Colditz G. Relation between changes in intakes of dietary fiber and grain products and changes in weight and development of obesity among middle-aged women. Am J Clin Nutr 2003; 78: 920-7.

22. Mosca CL, Marshall JA, Grunwald GK, Cornier MA, Baxter J. Insulin resistance as a modifier of the relationship between dietary fat intake and weight gain. Int $\mathbf{J}$ Obes Relat Metab Disord 2004; 28: 803-12.

23. Romaguera D, Angquist L, Du H, Jakobsen MU, Forouhi NG, Halkjaer J, et al. Dietary determinants of changes in waist circumference adjusted for body mass index - a proxy measure of visceral adiposity. PLoS ONE 2010; 5: e11588.

24. Savage JS, Marini M, Birch LL. Dietary energy density predicts women's weight change over 6 y. Am J Clin Nutr 2008; 88: 677-84.

25. Sherwood NE, Jeffery RW, French SA, Hannan PJ, Murray DM. Predictors of weight gain in the Pound of Prevention study. Int J Obes Relat Metab Disord 2000; 24: 395-403.

26. Tucker LA, Thomas KS. Increasing total fiber intake reduces risk of weight and fat gains in women. J Nutr 2009; 139: 576-81.

27. Bazzano LA, Song Y, Bubes V, Good CK, Manson JE, Liu S. Dietary intake of whole and refined grain breakfast cereals and weight gain in men. Obes Res 2005; 13: 1952-60.

28. Bes-Rastrollo M, Sánchez-Villegas A, Gómez-Gracia E, Martínez JA, Pajares RM, Martínez-González MA. Predictors of weight gain in a Mediterranean cohort: the Seguimiento Universidad de Navarra Study 1. Am J Clin Nutr 2006; 83: 362-370; quiz 394-395.

29. Bes-Rastrollo M, Sánchez-Villegas A, de la Fuente C, de Irala J, Martinez JA, Martínez-González MA. Olive oil consumption and weight change: the SUN prospective cohort study. Lipids 2006; 41: 249-56.

30. Bes-Rastrollo M, Wedick NM, Martinez-Gonzalez MA, Li TY, Sampson L, Hu FB. Prospective study of nut consumption, long-term weight change, and obesity risk in women. Am J Clin Nutr 2009; 89: 1913-9.

31. Du H, van der A DL, van Bakel MME, Slimani N, Forouhi NG, Wareham NJ, et al. Dietary glycaemic index, glycaemic load and subsequent changes of weight and waist circumference in European men and women. Int J Obes (Lond) 2009; 33: $1280-8$.

32. Halkjaer J, Sørensen TIA, Tjønneland A, Togo P, Holst C, Heitmann BL. Food and drinking patterns as predictors of 6year BMI-adjusted changes in waist circumference. Br J Nutr 2004; 92: 735-48.

33. Halkjaer J, Tjønneland A, Overvad K, Sørensen TIA. Dietary predictors of 5-year changes in waist circumference. J Am Diet Assoc 2009; 109: 1356-66.

34. Hare-Bruun H, Flint A, Heitmann BL. Glycemic index and glycemic load in relation to changes in body weight, body fat distribution, and body composition in adult Danes. Am J Clin Nutr 2006; 84: 871-879; quiz 952-953.

35. Koh-Banerjee P, Franz M, Sampson L, Liu S, Jacobs DR Jr, Spiegelman D, et al. Changes in whole-grain, bran, and cereal fiber consumption in relation to 8-y weight gain among men. Am J Clin Nutr 2004; 80: 1237-45.
36. Mozaffarian D, Hao T, Rimm EB, Willett WC, Hu FB. Changes in diet and lifestyle and long-term weight gain in women and men. N Engl J Med 2011; 364: 2392-404.

37. Poddar KH, Hosig KW, Nickols-Richardson SM, Anderson ES, Herbert WG, Duncan SE. Low-fat dairy intake and body weight and composition changes in college students. J Am Diet Assoc 2009; 109: 1433-8.

38. Rajpathak SN, Rimm EB, Rosner B, Willett WC, Hu FB. Calcium and dairy intakes in relation to long-term weight gain in US men. Am J Clin Nutr 2006; 83: 559-66.

39. Romaguera D, Ängquist L, Du H, Jakobsen MU, Forouhi NG, Halkjær J, et al. Food composition of the diet in relation to changes in waist circumference adjusted for body mass index. PLoS ONE 2011; 6: e23384.

40. Rosell M, Appleby P, Spencer E, Key T. Weight gain over 5 years in 21,966 meat-eating, fish-eating, vegetarian, and vegan men and women in EPIC-Oxford. Int J Obes (Lond) 2006; 30: 1389-96.

41. Rosell M, Håkansson NN, Wolk A. Association between dairy food consumption and weight change over 9 y in 19,352 perimenopausal women. Am J Clin Nutr 2006; 84: 1481-8.

42. Schulz M, Kroke A, Liese AD, Hoffmann K, Bergmann MM, Boeing $\mathrm{H}$. Food groups as predictors for short-term weight changes in men and women of the EPIC-Potsdam cohort. J Nutr 2002; 132: 1335-40.

43. Schulze MB, Manson JE, Ludwig DS, Colditz GA, Stampfer MJ, Willett WC, et al. Sugar-sweetened beverages, weight gain, and incidence of type 2 diabetes in young and middle-aged women. JAMA 2004; 292: 927-34.

44. Vergnaud A-C, Norat T, Romaguera D, Mouw T, May AM, Travier N, et al. Meat consumption and prospective weight change in participants of the EPIC-PANACEA study. Am J Clin Nutr 2010; 92: 398-407.

45. Vergnaud A-C, Norat T, Romaguera D, Mouw T, May AM, Romieu I, et al. Fruit and vegetable consumption and prospective weight change in participants of the European Prospective Investigation into Cancer and Nutrition-Physical Activity, Nutrition, Alcohol, Cessation of Smoking, Eating Out of Home, and Obesity study. Am J Clin Nutr 2012; 95: 184-93.

46. Vioque J, Weinbrenner T, Castelló A, Asensio L, Garcia de la Hera M. Intake of fruits and vegetables in relation to 10-year weight gain among Spanish adults. Obesity (Silver Spring) 2008; 16: 664-70.

47. Beunza J-J, Toledo E, Hu FB, Bes-Rastrollo M, SerranoMartínez M, Sánchez-Villegas A, et al. Adherence to the Mediterranean diet, long-term weight change, and incident overweight or obesity: the Seguimiento Universidad de Navarra (SUN) cohort. Am J Clin Nutr 2010; 92: 1484-93.

48. Quatromoni PA, Pencina M, Cobain MR, Jacques PF, D'Agostino RB. Dietary quality predicts adult weight gain: findings from the Framingham Offspring Study. Obesity (Silver Spring) 2006; 14: 1383-91.

49. Romaguera D, Norat T, Vergnaud A-C, Mouw T, May AM, Agudo A, et al. Mediterranean dietary patterns and prospective weight change in participants of the EPIC-PANACEA project. Am J Clin Nutr 2010; 92: 912-21.

50. Sánchez-Villegas A, Bes-Rastrollo M, Martínez-González MA, Serra-Majem L. Adherence to a Mediterranean dietary pattern and weight gain in a follow-up study: the SUN cohort. Int J Obes (Lond) 2006; 30: 350-8.

51. Zamora D, Gordon-Larsen P, Jacobs DR Jr, Popkin BM. Diet quality and weight gain among black and white young adults: the Coronary Artery Risk Development in Young Adults (CARDIA) Study (1985-2005). Am J Clin Nutr 2010; 92: 784-93. 
52. Brinkworth GD, Noakes M, Parker B, Foster P, Clifton PM. Long-term effects of advice to consume a high-protein, low-fat diet, rather than a conventional weight-loss diet, in obese adults with type 2 diabetes: one-year follow-up of a randomised trial. Diabetologia 2004; 47: 1677-86.

53. Dale KS, McAuley KA, Taylor RW, Williams SM, Farmer VL, Hansen P, et al. Determining optimal approaches for weight maintenance: a randomized controlled trial. CMAJ 2009; 180: E39-46.

54. Due A, Larsen TM, Mu H, Hermansen K, Stender S, Astrup A. Comparison of 3 ad libitum diets for weight-loss maintenance, risk of cardiovascular disease, and diabetes: a 6-mo randomized, controlled trial. Am J Clin Nutr 2008; 88: 1232 41.

55. Larsen TM, Dalskov S-M, van Baak M, Jebb SA, Papadaki A, Pfeiffer AFH, et al. Diets with high or low protein content and glycemic index for weight-loss maintenance. $\mathrm{N}$ Engl J Med 2010; 363: 2102-13.

56. Phelan S, Wyatt HR, Hill JO, Wing RR. Are the eating and exercise habits of successful weight losers changing? Obesity (Silver Spring) 2006; 14: 710-6.

57. Swinburn BA, Metcalf PA, Ley SJ. Long-term (5-year) effects of a reduced-fat diet intervention in individuals with glucose intolerance. Diabetes Care 2001; 24: 619-24.

58. White C, Drummond S, De Looy A. Comparing advice to decrease both dietary fat and sucrose, or dietary fat only, on weight loss, weight maintenance and perceived quality of life. Int J Food Sci Nutr 2010; 61: 282-94.

59. Delbridge EA, Prendergast LA, Pritchard JE, Proietto J. Oneyear weight maintenance after significant weight loss in healthy overweight and obese subjects: does diet composition matter? Am J Clin Nutr 2009; 90: 1203-14.

60. Bes-Rastrollo M, Sabaté J, Gómez-Gracia E, Alonso A, Martínez JA, Martínez-González MA. Nut consumption and weight gain in a Mediterranean cohort: the SUN study. Obesity (Silver Spring) 2007; 15: 107-16.

61. Field AE, Wing RR, Manson JE, Spiegelman DL, Willett WC. Relationship of a large weight loss to long-term weight change among young and middle-aged US women. Int $\mathrm{J}$ Obes Relat Metab Disord 2001; 25: 1113-21.

62. Anderson JW, Konz EC, Frederich RC, Wood CL. Long-term weight-loss maintenance: a meta-analysis of US studies. Am J Clin Nutr 2001; 74: 579-84.

63. Astrup A, Grunwald GK, Melanson EL, Saris WH, Hill JO. The role of low-fat diets in body weight control: a metaanalysis of ad libitum dietary intervention studies. Int $\mathbf{J}$ Obes Relat Metab Disord 2000; 24: 1545-52.

64. Ayyad C, Andersen T. Long-term efficacy of dietary treatment of obesity: a systematic review of studies published between 1931 and 1999. Obes Rev 2000; 1: 113-9.

65. Azadbakht L, Mirmiran P, Esmaillzadeh A, Azizi F. Better dietary adherence and weight maintenance achieved by a longterm moderate-fat diet. Br J Nutr 2007; 97: 399-404.

66. Bes-Rastrollo M, Martínez-González MA, Sánchez-Villegas A, de la Fuente Arrillaga C, Martínez JA. Association of fiber intake and fruit/vegetable consumption with weight gain in a Mediterranean population. Nutrition 2006; 22: 504-11.

67. Borg P, Fogelholm M, Kukkonen-Harjula K. Food selection and eating behaviour during weight maintenance intervention and 2-y follow-up in obese men. Int $\mathbf{J}$ Obes Relat Metab Disord 2004; 28: 1548-54.

68. Brown T, Avenell A, Edmunds LD, Moore H, Whittaker V, Avery L, et al. Systematic review of long-term lifestyle interventions to prevent weight gain and morbidity in adults. Obes Rev 2009; 10: 627-38.
69. Burke LE, Warziski M, Styn MA, Music E, Hudson AG, Sereika SM. A randomized clinical trial of a standard versus vegetarian diet for weight loss: the impact of treatment preference. Int J Obes (Lond) 2008; 32: 166-76.

70. Burke LE, Hudson AG, Warziski MT, Styn MA, Music E, Elci $\mathrm{OU}$, et al. Effects of a vegetarian diet and treatment preference on biochemical and dietary variables in overweight and obese adults: a randomized clinical trial. Am J Clin Nutr 2007; 86: 588-96.

71. Burke V, Mori TA, Giangiulio N, Gillam HF, Beilin LJ, Houghton $\mathrm{S}$, et al. An innovative program for changing health behaviours. Asia Pac J Clin Nutr 2002; 11(Suppl 3): S586-97.

72. Cardillo S, Seshadri P, Iqbal N. The effects of a lowcarbohydrate versus low-fat diet on adipocytokines in severely obese adults: three-year follow-up of a randomized trial. Eur Rev Med Pharmacol Sci 2006; 10: 99-106.

73. Carels RA, Darby LA, Douglass OM, Cacciapaglia HM, Rydin S. Education on the glycemic index of foods fails to improve treatment outcomes in a behavioral weight loss program. Eat Behav 2005; 6: 145-50.

74. Carnethon MR, Loria CM, Hill JO, Sidney S, Savage PJ, Liu $\mathrm{K}$. Risk factors for the metabolic syndrome: the Coronary Artery Risk Development in Young Adults (CARDIA) study, 1985-2001. Diabetes Care 2004; 27: 2707-15.

75. Carty CL, Kooperberg C, Neuhouser ML, Tinker L, Howard $\mathrm{B}$, Wactawski-Wende $\mathrm{J}$, et al. Low-fat dietary pattern and change in body-composition traits in the Women's Health Initiative Dietary Modification Trial. Am J Clin Nutr 2011; 93: 516-24.

76. Chen L, Appel LJ, Loria C, Lin P-H, Champagne CM, Elmer $\mathrm{PJ}$, et al. Reduction in consumption of sugar-sweetened beverages is associated with weight loss: the PREMIER trial. Am J Clin Nutr 2009; 89: 1299-306.

77. Cheskin LJ, Mitchell AM, Jhaveri AD, Mitola AH, Davis LM, Lewis RA, et al. Efficacy of meal replacements versus a standard food-based diet for weight loss in type 2 diabetes: a controlled clinical trial. Diabetes Educ 2008; 34: 118-27.

78. Clifton PM, Keogh JB, Noakes M. Long-term effects of a high-protein weight-loss diet. Am J Clin Nutr 2008; 87: 23-9.

79. Davis LM, Coleman C, Kiel J, Rampolla J, Hutchisen T, Ford $\mathrm{L}$, et al. Efficacy of a meal replacement diet plan compared to a food-based diet plan after a period of weight loss and weight maintenance: a randomized controlled trial. Nutr J 2010; 9: 11.

80. Ditschuneit HH, Flechtner-Mors M. Value of structured meals for weight management: risk factors and long-term weight maintenance. Obes Res 2001; 9(Suppl 4): S284S-9.

81. Djuric Z, Poore KM, Depper JB, Uhley VE, Lababidi S, Covington $\mathrm{C}$, et al. Methods to increase fruit and vegetable intake with and without a decrease in fat intake: compliance and effects on body weight in the nutrition and breast health study. Nutr Cancer 2002; 43: 141-51.

82. Due A, Toubro S, Skov AR, Astrup A. Effect of normal-fat diets, either medium or high in protein, on body weight in overweight subjects: a randomised 1-year trial. Int J Obes Relat Metab Disord 2004; 28: 1283-90.

83. Duffey KJ, Gordon-Larsen P, Jacobs DR Jr, Williams OD, Popkin BM. Differential associations of fast food and restaurant food consumption with 3-y change in body mass index: the Coronary Artery Risk Development in Young Adults Study. Am J Clin Nutr 2007; 85: 201-8.

84. Eckel RH, Hernandez TL, Bell ML, Weil KM, Shepard TY, Grunwald GK, et al. Carbohydrate balance predicts weight and fat gain in adults. Am J Clin Nutr 2006; 83: 803-8.

85. Farshchi HR, Taylor MA, Macdonald IA. Decreased thermic effect of food after an irregular compared with a regular meal 
pattern in healthy lean women. Int J Obes Relat Metab Disord 2004; 28: 653-60.

86. Flechtner-Mors M, Boehm BO, Wittmann R, Thoma U, Ditschuneit HH. Enhanced weight loss with protein-enriched meal replacements in subjects with the metabolic syndrome. Diabetes Metab Res Rev 2010; 26: 393-405.

87. French SA, Harnack L, Jeffery RW. Fast food restaurant use among women in the Pound of Prevention study: dietary, behavioral and demographic correlates. Int J Obes Relat Metab Disord 2000; 24: 1353-9.

88. Greene LF, Malpede CZ, Henson CS, Hubbert KA, Heimburger DC, Ard JD. Weight maintenance 2 years after participation in a weight loss program promoting low-energy density foods. Obesity (Silver Spring) 2006; 14: 1795-801.

89. Hensrud DD. Dietary treatment and long-term weight loss and maintenance in type 2 diabetes. Obes Res 2001; 9(Suppl 4): S348-53.

90. Hoy MK, Winters BL, Chlebowski RT, Papoutsakis C, Shapiro A, Lubin MP, et al. Implementing a low-fat eating plan in the Women's Intervention Nutrition Study. J Am Diet Assoc 2009; 109: 688-96.

91. Jehn ML, Patt MR, Appel LJ, Miller ER 3rd. One year followup of overweight and obese hypertensive adults following intensive lifestyle therapy. J Hum Nutr Diet 2006; 19: 349-54.

92. Karnehed N, Tynelius P, Heitmann BL, Rasmussen F. Physical activity, diet and gene-environment interactions in relation to body mass index and waist circumference: the Swedish young male twins study. Public Health Nutr 2006; 9: 851-8.

93. Kaukua JK, Pekkarinen TA, Rissanen AM. Health-related quality of life in a randomised placebo-controlled trial of sibutramine in obese patients with type II diabetes. Int J Obes Relat Metab Disord 2004; 28: 600-5.

94. Keogh JB, Luscombe-Marsh ND, Noakes M, Wittert GA, Clifton PM. Long-term weight maintenance and cardiovascular risk factors are not different following weight loss on carbohydrate-restricted diets high in either monounsaturated fat or protein in obese hyperinsulinaemic men and women. Br J Nutr 2007; 97: 405-10.

95. Kristal AR, Curry SJ, Shattuck AL, Feng Z, Li S. A randomized trial of a tailored, self-help dietary intervention: the Puget Sound Eating Patterns study. Prev Med 2000; 31: 380-9.

96. Kuller LH, Simkin-Silverman LR, Wing RR, Meilahn EN, Ives DG. Women's healthy lifestyle project: a randomized clinical trial: results at 54 months. Circulation 2001; 103: 32-7.

97. Lantz H, Peltonen M, Agren L, Torgerson JS. Intermittent versus on-demand use of a very low calorie diet: a randomized 2-year clinical trial. J Intern Med 2003; 253: 463-71.

98. Layman DK, Evans EM, Erickson D, Seyler J, Weber J, Bagshaw D, et al. A moderate-protein diet produces sustained weight loss and long-term changes in body composition and blood lipids in obese adults. J Nutr 2009; 139: 514-21.

99. Lejeune MPGM, Kovacs EMR, Westerterp-Plantenga MS. Additional protein intake limits weight regain after weight loss in humans. Br J Nutr 2005; 93: 281-9.

100. Leser MS, Yanovski SZ, Yanovski JA. A low-fat intake and greater activity level are associated with lower weight regain 3 years after completing a very-low-calorie diet. J Am Diet Assoc 2002; 102: 1252-6.

101. Lindström J, Louheranta A, Mannelin M, Rastas M, Salminen V, Eriksson J, et al. The Finnish Diabetes Prevention Study (DPS): lifestyle intervention and 3-year results on diet and physical activity. Diabetes Care 2003; 26: 3230-6.

102. Macdonald HM, New SA, Campbell MK, Reid DM. Longitudinal changes in weight in perimenopausal and early postmenopausal women: effects of dietary energy intake, energy expenditure, dietary calcium intake and hormone replacement therapy. Int J Obes Relat Metab Disord 2003; 27: 669-76.

103. Marinilli Pinto A, Gorin AA, Raynor HA, Tate DF, Fava JL, Wing RR. Successful weight-loss maintenance in relation to method of weight loss. Obesity (Silver Spring) 2008; 16: 2456 61.

104. McAuley KA, Smith KJ, Taylor RW, McLay RT, Williams SM, Mann JI. Long-term effects of popular dietary approaches on weight loss and features of insulin resistance. Int $\mathrm{J}$ Obes (Lond) 2006; 30: 342-9.

105. Moore CS, Lindroos AK, Kreutzer M, Larsen TM, Astrup A, van Baak MA, et al. Dietary strategy to manipulate ad libitum macronutrient intake, and glycaemic index, across eight European countries in the Diogenes Study. Obes Rev 2010; 11: $67-75$.

106. Moran LJ, Noakes M, Clifton PM, Wittert GA, Williams G, Norman RJ. Short-term meal replacements followed by dietary macronutrient restriction enhance weight loss in polycystic ovary syndrome. Am J Clin Nutr 2006; 84: 77-87.

107. Mozaffarian D, Marfisi R, Levantesi G, Silletta MG, Tavazzi $\mathrm{L}$, Tognoni $\mathrm{G}$, et al. Incidence of new-onset diabetes and impaired fasting glucose in patients with recent myocardial infarction and the effect of clinical and lifestyle risk factors. Lancet 2007; 370: 667-75.

108. Ochner CN, Lowe MR. Self-reported changes in dietary calcium and energy intake predict weight regain following a weight loss diet in obese women. J Nutr 2007; 137: 2324-8.

109. Packianathan I, Sheikh M, Boniface D, Finer N. Predictors of programme adherence and weight loss in women in an obesity programme using meal replacements. Diabetes Obes Metab 2005; 7: 439-47.

110. Palmer JR, Boggs DA, Krishnan S, Hu FB, Singer M, Rosenberg L. Sugar-sweetened beverages and incidence of type 2 diabetes mellitus in African American women. Arch Intern Med 2008; 168: 1487-92.

111. Poppitt SD, Keogh GF, Prentice AM, Williams DEM, Sonnemans HMW, Valk EEJ, et al. Long-term effects of ad libitum low-fat, high-carbohydrate diets on body weight and serum lipids in overweight subjects with metabolic syndrome. Am J Clin Nutr 2002; 75: 11-20.

112. Raynor HA, Jeffery RW, Tate DF, Wing RR. Relationship between changes in food group variety, dietary intake, and weight during obesity treatment. Int $\mathbf{J}$ Obes Relat Metab Disord 2004; 28: 813-20.

113. Razquin C, Martinez JA, Martinez-Gonzalez MA, Mitjavila MT, Estruch R, Marti A. A 3 years follow-up of a Mediterranean diet rich in virgin olive oil is associated with high plasma antioxidant capacity and reduced body weight gain. Eur J Clin Nutr 2009; 63: 1387-93.

114. Redman LM, Heilbronn LK, Martin CK, de Jonge L, Williamson DA, Delany JP, et al. Metabolic and behavioral compensations in response to caloric restriction: implications for the maintenance of weight loss. PLoS ONE 2009; 4: e4377.

115. Riebe D, Blissmer B, Greene G, Caldwell M, Ruggiero L, Stillwell KM, et al. Long-term maintenance of exercise and healthy eating behaviors in overweight adults. Prev Med 2005; 40: 769-78.

116. Sacks FM, Bray GA, Carey VJ, Smith SR, Ryan DH, Anton $\mathrm{SD}$, et al. Comparison of weight-loss diets with different compositions of fat, protein, and carbohydrates. N Engl J Med 2009; 360: 859-73.

117. Saris WH. Very-low-calorie diets and sustained weight loss. Obes Res 2001; 9(Suppl 4): S295-301.

118. Saris WH, Astrup A, Prentice AM, Zunft HJ, Formiguera X, Verboeket-van de Venne WP, et al. Randomized controlled 
trial of changes in dietary carbohydrate/fat ratio and simple vs complex carbohydrates on body weight and blood lipids: the CARMEN study. The Carbohydrate Ratio Management in European National diets. Int J Obes Relat Metab Disord 2000; 24: $1310-8$.

119. Sasaki S, Ishikawa T, Yanagibori R, Amano K. Change and 1-year maintenance of nutrient and food group intakes at a 12week worksite dietary intervention trial for men at high risk of coronary heart disease. J Nutr Sci Vitaminol 2000; 46: 15-22.

120. Schoeller DA, Watras AC, Whigham LD. A meta-analysis of the effects of conjugated linoleic acid on fat-free mass in humans. Appl Physiol Nutr Metab 2009; 34: 975-8.

121. Sichieri R, Moura AS, Genelhu V, Hu F, Willett WC. An 18mo randomized trial of a low-glycemic-index diet and weight change in Brazilian women. Am J Clin Nutr 2007; 86: 707-13.

122. Simkin-Silverman LR, Wing RR, Boraz MA, Kuller LH. Lifestyle intervention can prevent weight gain during menopause: results from a 5-year randomized clinical trial. Ann Behav Med 2003; 26: 212-20.

123. Sloth B, Due A, Larsen TM, Holst JJ, Heding A, Astrup A. The effect of a high-MUFA, low-glycaemic index diet and a low-fat diet on appetite and glucose metabolism during a 6-month weight maintenance period. Br J Nutr 2009; 101: 1846-58.

124. Steptoe A, Kerry S, Rink E, Hilton S. The impact of behavioral counseling on stage of change in fat intake, physical activity, and cigarette smoking in adults at increased risk of coronary heart disease. Am J Public Health 2001; 91: 265-9.

125. Stookey JD, Adair LS, Popkin BM. Do protein and energy intakes explain long-term changes in body composition? J Nutr Health Aging 2005; 9: 5-17.

126. Stote KS, Baer DJ, Spears K, Paul DR, Harris GK, Rumpler $\mathrm{WV}$, et al. A controlled trial of reduced meal frequency without caloric restriction in healthy, normal-weight, middle-aged adults. Am J Clin Nutr 2007; 85: 981-8.

127. Svetkey LP, Stevens VJ, Brantley PJ, Appel LJ, Hollis JF, Loria $\mathrm{CM}$, et al. Comparison of strategies for sustaining weight loss: the weight loss maintenance randomized controlled trial. JAMA 2008; 299: 1139-48.

128. Thorpe MP, Jacobson EH, Layman DK, He X, Kris-Etherton PM, Evans EM. A diet high in protein, dairy, and calcium attenuates bone loss over twelve months of weight loss and maintenance relative to a conventional high-carbohydrate diet in adults. J Nutr 2008; 138: 1096-100.

129. Turk MW, Yang K, Hravnak M, Sereika SM, Ewing LJ, Burke LE. Randomized clinical trials of weight loss maintenance: a review. J Cardiovasc Nurs 2009; 24: 58-80.

130. Turner-McGrievy GM, Barnard ND, Scialli AR. A two-year randomized weight loss trial comparing a vegan diet to a more moderate low-fat diet. Obesity (Silver Spring) 2007; 15: 2276-81.

131. van de Vijver LPL, van den Bosch LMC, van den Brandt PA, Goldbohm RA. Whole-grain consumption, dietary fibre intake and body mass index in the Netherlands cohort study. Eur J Clin Nutr 2009; 63: 31-8.

132. Vang A, Singh PN, Lee JW, Haddad EH, Brinegar CH. Meats, processed meats, obesity, weight gain and occurrence of diabetes among adults: findings from adventist health studies. Ann Nutr Metab 2008; 52: 96-104.

133. Wang L, Lee I-M, Manson JE, Buring JE, Sesso HD. Alcohol consumption, weight gain, and risk of becoming overweight in middle-aged and older women. Arch Intern Med 2010; 170: 453-61.

134. Whigham LD, Watras AC, Schoeller DA. Efficacy of conjugated linoleic acid for reducing fat mass: a meta-analysis in humans. Am J Clin Nutr 2007; 85: 1203-11.

135. Woo J, Cheung B, Ho S, Sham A, Lam TH. Influence of dietary pattern on the development of overweight in a Chinese population. Eur J Clin Nutr 2008; 62: 480-7.

136. Ashwell M, Gunn P, Gibson S. Waist-to-height ratio is a better screening tool than waist circumference and BMI for adult cardiometabolic risk factors: systematic review and metaanalysis. Obes Rev 2012; 13: 275-86.

137. Freiberg MS, Pencina MJ, D'Agostino RB, Lanier K, Wilson PWF, Vasan RS. BMI vs. waist circumference for identifying vascular risk. Obesity (Silver Spring) 2008; 16: 463-9.

138. Hätönen KA, Similä ME, Virtamo JR, Eriksson JG, Hannila M-L, Sinkko HK, et al. Methodologic considerations in the measurement of glycemic index: glycemic response to rye bread, oatmeal porridge, and mashed potato. Am J Clin Nutr 2006; 84: 1055-61.

139. Isaksson H, Fredriksson H, Andersson R, Olsson J, Aman P. Effect of rye bread breakfasts on subjective hunger and satiety: a randomized controlled trial. Nutr J 2009; 8: 39.

140. Sabaté J. Nut consumption and body weight. Am J Clin Nutr 2003; 78: 647S-50S.

141. Sabaté J, Oda K, Ros E. Nut consumption and blood lipid levels: a pooled analysis of 25 intervention trials. Arch Intern Med 2010; 170: 821-7.

142. Ludwig DS. Dietary glycemic index and obesity. J Nutr 2000; 130: 280S-3S.

143. Zemel MB. Proposed role of calcium and dairy food components in weight management and metabolic health. Phys Sportsmed 2009; 37: 29-39.

144. Soares MJ, Cummings SJ, Mamo JCL, Kenrick M, Piers LS. The acute effects of olive oil $\mathrm{v}$. cream on postprandial thermogenesis and substrate oxidation in postmenopausal women. Br J Nutr 2004; 91: 245-52.

145. Veldhorst MAB, Westerterp KR, Westerterp-Plantenga MS Gluconeogenesis and protein-induced satiety. Br J Nutr 2012; 107: 595-600.

146. O'Neil CE, Fulgoni VL 3rd, Nicklas TA. Association of candy consumption with body weight measures, other health risk factors for cardiovascular disease, and diet quality in US children and adolescents: NHANES 1999-2004. Food Nutr Res 2011; 55. http://www.ncbi.nlm.nih.gov/pubmed/21691462 [cited 8 Feb 2012].

147. Lawlor DA, Davey Smith G, Kundu D, Bruckdorfer KR, Ebrahim S. Those confounded vitamins: what can we learn from the differences between observational versus randomised trial evidence? Lancet 2004; 363: 1724-7.

*Mikael Fogelholm
Department of Food and Environmental Sciences
University of Helsinki
POB 66
00014 Helsinki
Finland
Email: mikael.fogelholm@helsinki.fi




\section{Appendix I}

Search terms:

Set I

(I) Dietary carbohydrates.mesh. OR

(2) Dietary fats.mesh. OR (as free text) 'saturated fats' OR 'monounsaturated fats' OR 'polyunsaturated fats' [TI, AB] OR

(3) Fatty acids, unsaturated.mesh. OR

(4) Proteins.mesh. OR

(5) Dietary fiber.mesh. OR

(6) Energy intake.mesh. OR

(7) Diet, Carbohydrate-Restricted.mesh. OR

(8) Diet, fat-restricted.mesh. OR

(9) Diet, Mediterranean.mesh. OR

(I0) Diet, Protein-restricted.mesh. OR

(I I) Diet, vegetarian.mesh. OR

(I2) Ketogenic diet.mesh.

AND

\section{Set II}

(I) Body weight.mesh. (narrower terms: overweight.mesh., including obesity.mesh.) OR

(2) Waist-Hip Ratio.mesh. OR 'waist girth' OR

(3) Waist Circumference.mesh. OR

(4) Body composition.mesh. (incl. narrower term: body fat distribution.mesh. and adiposity.mesh.) OR

(5) Adipose tissue.mesh. (incl. narrower term: abdominal fat.mesh.) OR 'body fat' OR

(6) body mass index.mesh. OR 'fat mass'

AND

\section{Set III}

maintenance* OR gain* OR regain* (cannot use too common words, like: change OR changes OR changing)

\section{Set I and Set II and Set III=Group I}

\section{Set IV}

weight gain.mesh.

OR

'weight gain' OR 'Gain, Weight' OR 'Gains, Weight' OR 'Weight Gains' [TI, AB]

\section{Set I AND Set IV = Group II}

Group I

OR

Group II

AND

RCT. PT OR mesh

$\mathrm{OR}$

cohort studies.mesh. (incl. term: longitudinal studies.mesh. OR prospective studies.mesh.)

OR

intervention studies.mesh.

OR 
meta-analysis, mesh OR pt

OR

'systematic review' OR 'systematic reviews' OR 'Cochrane database syst rev'

OR 'randomised controlled' OR 'randomised controlled' OR meta-analysis

human, 2000

\section{Appendix 2}

Reasons for excluding full papers $(n=78)$ from the quality grading

\begin{tabular}{|c|c|}
\hline References & Reason for exclusion \\
\hline Anderson et al. (62) & Macronutrient data not shown \\
\hline Astrup (5) & Review, but concentrates on weight reduction only (not on weight management) \\
\hline Astrup et al. (63) & Concentrates on weight reduction only \\
\hline Ayyad et al. (64) & No macronutrient data, review on weight loss mainly \\
\hline Azadbakht et al. (65) & Weight reduction only \\
\hline Bes-Rastrollo et al. (66) & Cross-sectional study \\
\hline Borg et al. (67) & $\begin{array}{l}\text { Originally included in the evaluation but excluded from quality grading: no data on food vs. weight change in a } \\
\text { prospective design }\end{array}$ \\
\hline Brown et al. (68) & $\begin{array}{l}\text { Originally included in the evaluation but excluded from quality grading: the review concentrated on weight reduction } \\
\text { interventions with special diets }\end{array}$ \\
\hline Burke et al. (70) & No macronutrient data \\
\hline Burke et al. (69) & Weight reduction only \\
\hline Burke et al. (7I) & Physical activity and nutrition combined, not clear maintenance phase \\
\hline Cardillo et al. (72) & $\begin{array}{l}\text { Originally included in the evaluation but excluded from quality grading: weight loss was different between the groups } \\
\text { initially }\end{array}$ \\
\hline Carels et al. (73) & Weight reduction only \\
\hline Carnethon et al. (74) & No results on weight change, $\mathrm{MBO}$ as an outcome \\
\hline Carty et al. (75) & $\begin{array}{l}\text { Originally included in the evaluation but excluded from quality grading: same data as Howard et al. (18), but this is a } \\
\text { subset with a smaller number of cases }\end{array}$ \\
\hline Chen et al. (76) & Weight reduction only \\
\hline Cheskin et al. (77) & Meal replacements, weight reduction only, no dietary data \\
\hline Clifton et al. (78) & Weight reduction only \\
\hline Davis et al. (79) & Meal replacements, weight reduction only, follow-up less than 6 months \\
\hline Ditschuneit et al. (80) & Meal replacements, weight reduction only \\
\hline Djuric et al. (8I) & $\begin{array}{l}\text { Originally included in the evaluation but excluded from quality grading: effects on body weight varied by groups } \\
\text { during the first } 3 \text { months of the intervention; weight reduction study }\end{array}$ \\
\hline Due et al. (82) & Weight reduction only \\
\hline Duffey et al. (83) & Only eating patterns, no macronutrient data \\
\hline Eckel et al. (84) & No dietary data \\
\hline Farshchi et al. (85) & Experimental study, focused on meal pattern and thermic effect of food \\
\hline Flechtner-Mors et al. (86) & Meal replacements, weight reduction only \\
\hline Forshee et al. (10) & Originally included in the evaluation but excluded from quality grading: review \\
\hline French et al. (87) & $\begin{array}{l}\text { Originally included in the evaluation but excluded from quality grading: study on visits to fast food restaurants and } \\
\text { dietary, behavioural and demographic correlates }\end{array}$ \\
\hline Gibson (8) & Originally included in the evaluation but excluded from quality grading: review \\
\hline Greene et al. (88) & $\begin{array}{l}\text { Originally was included in the evaluation but excluded from SLR: weight loss was different between the groups } \\
\text { initially }\end{array}$ \\
\hline Hensrud (89) & Not a systematic review \\
\hline Hoy et al. (90) & Study on cancer patients \\
\hline Jehn et al. (91) & Physical activity and nutrition combined \\
\hline Karnehed et al. (92) & $\begin{array}{l}\text { Originally included in the evaluation but excluded from quality grading: dietary data were collected only at follow-up, } \\
\text { not at baseline }\end{array}$ \\
\hline
\end{tabular}


Appendix 2 (Contiuned)

References

Reason for exclusion

Kaukua et al. (93)

Keogh et al. (94)

Kristal et al. (95)

Kuller et al. (96)

Lantz et al. (97)

Layman et al. (98)

Lejeune et al. (99)

Leser et al. (100)

Lindstrom et al. (I0I)

Macdonald et al. (102)

Malik et al. (9)

Marinilli Pinto et al. (I03)

McAuley et al. (104)

Moore et al. (I05)

Moran et al. (106)

Mozaffarian et al. (107)

Ochner et al. (108)

Packianathan et al. (109)

Palmer et al. (I I0)

Poppitt et al. (I I I)

Raynor et al. (I I2)

Razquin et al. (I I3)

Redman et al. (I |4)

Riebe et al. (II5)

Sacks et al. (1 I6)

Saris (I I7)

Saris et al. (1 18)

Sasaki et al. (I19)

Schoeller et al. (120)

Sichieri et al. (12I)

Simkin-Silverman et al. (122)

Sloth et al. (123)

Steptoe et al. (124)

Stookey et al. (125)

Stote et al. (126)

Svetkey et al. (127)

Thorpe et al. (128)

Turk et al. (129)

Turner-McGrievy et al. (I30)

van de Vijver et al. (I3I)

Vang et al. (I32)

Wang et al. (133)

Whigham et al. (134)

Woo et al. (I35)
No dietary data

Weight reduction only

No results on weight change

Physical activity and nutrition combined

Weight reduction only, comparisons between VLCDs

Weight reduction only

Originally included in the evaluation but excluded from quality grading: dietary intake not assessed, except for protein intake by urine analysis. Protein supplement used to increase protein intake

Originally included in the evaluation but excluded from quality grading: very small sample size, dietary intake assessed only in the end of the study, only fat-intake reported, PA assessed, but not used to adjust the results

Physical activity and nutrition combined

Macronutrient data not shown

Originally included in the evaluation but excluded from quality grading: review

Study on counseling, only weight loss results

Weight reduction only

Description of a study, no results included

Meal replacements, weight reduction only

No results on weight change

Macronutrient data not shown, mixed race

No macronutrient data, meal replacements, weight reduction only

Race: African-American, weight not an outcome

Weight reduction only, short follow-up (6 months)

Exercise intervention, study on weight loss, no clear data on macronutrients

Originally included in the evaluation but excluded from quality grading: the participants were mostly overweight and obese and had high-risk for cardiovascular diseases; e.g. Type 2 diabetes was an inclusion criteria

Weight reduction only

Physical activity and nutrition combined

Weight reduction only

No dietary intake data

Weight reduction only

No results on weight change

Study on CLA treatment, no diet, weight reduction only

Originally included in the evaluation but excluded from quality grading: this is a weight reduction study

Physical activity and nutrition combined

Originally included in the evaluation but excluded from quality grading: same database as in Due et al. (82) but fewer cases

No results on weight change, multiple interventions

Race: only Asian (Chinese)

No macronutrient data, study on meal frequency

No macronutrient data, mixed race

Weight reduction only

Originally included in the evaluation but excluded from quality grading: review

Weight reduction only

Cross-sectional design

No results on weight change, no macronutrient data

Data on alcohol consumption only

Study on CLA treatment, no diet, weight reduction only

Race: only Asian (Chinese) 


\section{Appendix 3}

\section{Evidence tables}

Table 1. Macronutrients and prevention of weight gain

\begin{tabular}{|c|c|c|c|c|c|c|c|c|c|c|c|c|}
\hline $\begin{array}{l}\text { Reference } \\
\text { details, First } \\
\text { author, Year, } \\
\text { Country }\end{array}$ & $\begin{array}{l}\text { Study } \\
\text { design } \\
\text { (RCT, CT, } \\
\text { cohort, } \\
\text { case } \\
\text { control } \\
\text { etc.) }\end{array}$ & $\begin{array}{l}\text { Population, subject } \\
\text { characteristics, } \\
\text { Inclusion/exclusion } \\
\text { criteria, setting, no. } \\
\text { at baseline, male/ } \\
\text { female, age, ethnicity } \\
\text { of the subjects, } \\
\text { anthropometry, } \\
\text { location }\end{array}$ & $\begin{array}{l}\text { Outcome } \\
\text { measures } \\
\text { Disease, } \\
\text { biological } \\
\text { measures }\end{array}$ & $\begin{array}{l}\text { Intervention/ } \\
\text { exposure }\end{array}$ & $\begin{array}{l}\text { Time between } \\
\text { baseline } \\
\text { exposure and } \\
\text { outcome } \\
\text { assessment }\end{array}$ & $\begin{array}{l}\text { Dietary } \\
\text { assessment } \\
\text { method } \\
\text { FFQ, food } \\
\text { record } \\
\text { Internal } \\
\text { validation } \\
(y / n)\end{array}$ & $\begin{array}{l}\text { No of } \\
\text { subjects } \\
\text { analysed }\end{array}$ & $\begin{array}{l}\text { Intervention } \\
\text { (I) (dose } \\
\text { interval, } \\
\text { duration), } \\
\text { Control (C) } \\
\text { (active, } \\
\text { placebo, usual } \\
\text { care etc), } \\
\text { compliance, } \\
\text { achieved } \\
\text { dietary } \\
\text { change, } \\
\text { adherence to } \\
\text { dietary } \\
\text { targets, actual } \\
\text { dietary } \\
\text { change }\end{array}$ & $\begin{array}{l}\text { Follow-up } \\
\text { period, } \\
\text { drop-out rate } \\
\text { (from baseline } \\
\text { to follow-up, } \\
\text { or from end of } \\
\text { intervention to } \\
\text { follow-up) } \\
\text { Drop out (\%) }\end{array}$ & $\begin{array}{l}\text { Results (I, C) } \\
\text { (Absolute } \\
\text { difference, RR, } \\
\text { OR, } p \text {-value, } \\
\text { confidence interval, } \\
\text { sensitivity, specificity, } \\
\text { observer reliability? } \\
\text { etc.) }\end{array}$ & $\begin{array}{l}\text { Confounders } \\
\text { adjusted for }\end{array}$ & $\begin{array}{l}\text { Study quality } \\
\text { and } \\
\text { relevance, } \\
\text { Comments } \\
\text { (A-C) }\end{array}$ \\
\hline $\begin{array}{l}\text { Bes-Rastrollo, } \\
2008 \text {, US } \\
\text { (12) }\end{array}$ & Cohort & $\begin{array}{l}\text { Nurses' health study, } \\
|16,67| \text { women, age } \\
36.5 \text { ( } 4.6) \text { y } \\
\text { Excluded at } \\
\text { baseline (199I) if did } \\
\text { not complete FFQ, if } \\
\text { they reported El } \\
\text { ( }<500 \text { or }>3,500 \\
\text { kcal/day), history of } \\
\text { diabetes or CVD, } \\
\text { cancer before I999 } \\
\text { (post test), pregnancy } \\
\text { at any time from } \\
\text { baseline to post test, } \\
\text { no PA data assessed } \\
\text { in } 199 \mid \text { and } 1997 \text {, } \\
\text { only baseline data, } \\
\text { missing Wt data. } \\
\text { Final } n=51,188 \text {. }\end{array}$ & $\begin{array}{l}\text { Wt gain } \\
\text { (self-report). }\end{array}$ & $\begin{array}{l}\text { Change in } \\
\text { dietary ED } \\
\text { (defined as } \\
\text { the amount of } \\
\text { energy in a } \\
\text { given weight } \\
\text { of food). }\end{array}$ & $8 \mathrm{y}$ & I33-item FFQ & $n=50,026$ & & $\begin{array}{l}8 \text { y. Dropout } \\
57 \% \text {. }\end{array}$ & $\begin{array}{l}\text { W who increased } \\
\text { dietary ED during } \\
\text { follow-up the most } \\
\text { had a significantly } \\
\text { greater weight gain } \\
\text { than those who } \\
\text { decreased ED the } \\
\text { most: } 6.42 \text { vs. } 4.57 \mathrm{~kg} \\
\text { ( } p \text { for trend }<0.001 \text { ). }\end{array}$ & $\begin{array}{l}\text { Age, baseline } \\
\text { alcohol intake, } \\
\text { PA, smoking, } \\
\text { postmenopausal } \\
\text { hormone use, } \\
\text { oral } \\
\text { contraceptives, } \\
\text { cereal fibre } \\
\text { intake, TFA } \\
\text { intake, baseline } \\
\text { BMI, change in } \\
\text { intake of SSSDs } \\
\text { and changes in } \\
\text { confounders } \\
\text { between time } \\
\text { periods. }\end{array}$ & $\begin{array}{l}\text { B } \\
\text { Weight } \\
\text { self-reported. } \\
\text { Details of } \\
\text { dietary } \\
\text { assessments } \\
\text { were lacking } \\
\text { in this report, } \\
\text { although they } \\
\text { have been } \\
\text { reported } \\
\text { earlier. The } \\
\text { comparability } \\
\text { of this } \\
\text { population } \\
\text { (nurses from } \\
\text { the US) and } \\
\text { Nordic } \\
\text { population is } \\
\text { not clear. }\end{array}$ \\
\hline
\end{tabular}


Du, 2009; Italy, Cohort UK, The Germany,

Denmark
Eight cities/counties in Changes in wt Dietary ED

Italy, UK, The and WC.

Netherlands,

Measured at

baseline and

$20-78 y, n=1$

baseline (1992-1998), follow-up.

$n=102,346$ at follow Otherwise

up (1998-2005), self report.

missing information on

diet, anthropometry

or follow-up time,

El/BMR in the top or

bottom $1 \%$ of EPIC

population, unrealistic

anthropometric

measures,

history of cancer,

diabetes or CVD at

baseline.

\section{Du, 2010, the Cohort Netherlands}

(five

countries)

(14)

\section{Eight cities/counties}

in Italy, UK, The

Netherlands, G

and Denmark

Change in wt Fibre intake: $6.5 \mathrm{y}$

and WC;

total, cereal (1.9-12.5 y)

measured wt, fibre, and fruit

(DiOGenes), age

ht and $W C$ at and vegetable

$20-78 y, n=146,543$ at in 2 (out of 8 )

baseline (1992-1998), centres at

$n=102,346$ at follow follow-up,

up (1998-2005), excl. self-reported

pregnancy, missing in six centre

formation on diet,

anthrop, or follow-up

duration, El/BMR in

the top or bottom

$1 \%$ of EPIC population,

unrealistic anthrop

measures, presence of

chronic diseases;

baseline BMI 25.5-26.7

$\mathrm{kg} / \mathrm{m}^{2}$ for $M$ and

$24.4-25.8 \mathrm{~kg} / \mathrm{m}^{2}$ for $\mathrm{W}$,

WC $90-95 \mathrm{~cm}$ for

men and $77-86 \mathrm{~cm}$

for women.

$\begin{array}{lll}6.5(1.9-12.5) \text { y } & \text { Country- } \quad n=89,432 \\ & \text { specific FFQ, } \quad(42 \% \mathrm{M}) \\ & \text { self-administered } \\ & \text { at baseline. } \\ & \text { Intake calculated } \\ & \text { using country- } \\ & \text { specific food } \\ & \text { composition } \\ & \text { tables. ED } \\ & \text { calculated as El } \\ & \text { from food } \\ & \text { divided by the } \\ & \text { weights of these } \\ & \text { foods. Drinks } \\ & \text { (water, alcohol, } \\ & \text { milk) not } \\ & \text { included. }\end{array}$

Country- $\quad n=89,432$

specific FFQs at $(42 \% \mathrm{M})$

baseline. For

validation

reference, see

the original

article.

Enzymatic-

gravimetric

method (AOAC)

to define dietary

fibre, except in

UK where

defined as

non-starch

polysaccharides

using Englyst

method
$6.5(1.9-12.5)$ y ED was not associated Age, sex baseline $B$

with weight change, wt, ht and WC, Large multi-

but significantly with smoking, PA, centre study

WC. For I kcal/g ED education, with large

annual WC change follow-up time, variation in

was $0.09 \mathrm{~cm} / \mathrm{y}(95 \%$ alcohol, El from results

Cl: 001-018)

beverages for between

women: also centres which

menopausal are difficult to

status and adjust for

hormone even though

use.

en thoug

advanced

between

measured and

self-reported

body wt.

\begin{tabular}{|c|c|c|}
\hline $\begin{array}{l}6.5 . y \text { on } \\
\text { average Drop- } \\
\text { out } 31.2 \%\end{array}$ & $\begin{array}{l}10 \mathrm{~g} \text { fibre intake } \\
\text { associated with }-39 \mathrm{~g} \\
(95 \% \mathrm{Cl}-7 \mathrm{l} \text { to }-7 \\
\mathrm{g}) \mathrm{wt} \text { change/year and } \\
-0.08 \mathrm{~cm}(-0.1 \mathrm{l}, \\
-0.05 \mathrm{~cm}) \text { change in } \\
\mathrm{WC} / \mathrm{y} \text {, } \\
10 \mathrm{~g} \text { cereal fibre assoc } \\
\text { with }-77 \mathrm{~g}(-127 \text {, } \\
-26 \mathrm{~g}) \mathrm{wt} \text { change per } \\
\text { year, }-0.10 \mathrm{~cm} \\
(-0.18,0.02 \mathrm{~cm}) \\
\text { change in WC/y. }\end{array}$ & $\begin{array}{l}\text { Age, sex, } \\
\text { baseline wt, ht } \\
\text { and WC, } \\
\text { smoking, PA, } \\
\text { education, } \\
\text { alcohol, Gl, } \\
\text { intake of } \\
\text { protein, fat and } \\
\text { CHD, total El, in } \\
\text { W menopausal } \\
\text { status and } \\
\text { hormone use. }\end{array}$ \\
\hline
\end{tabular}




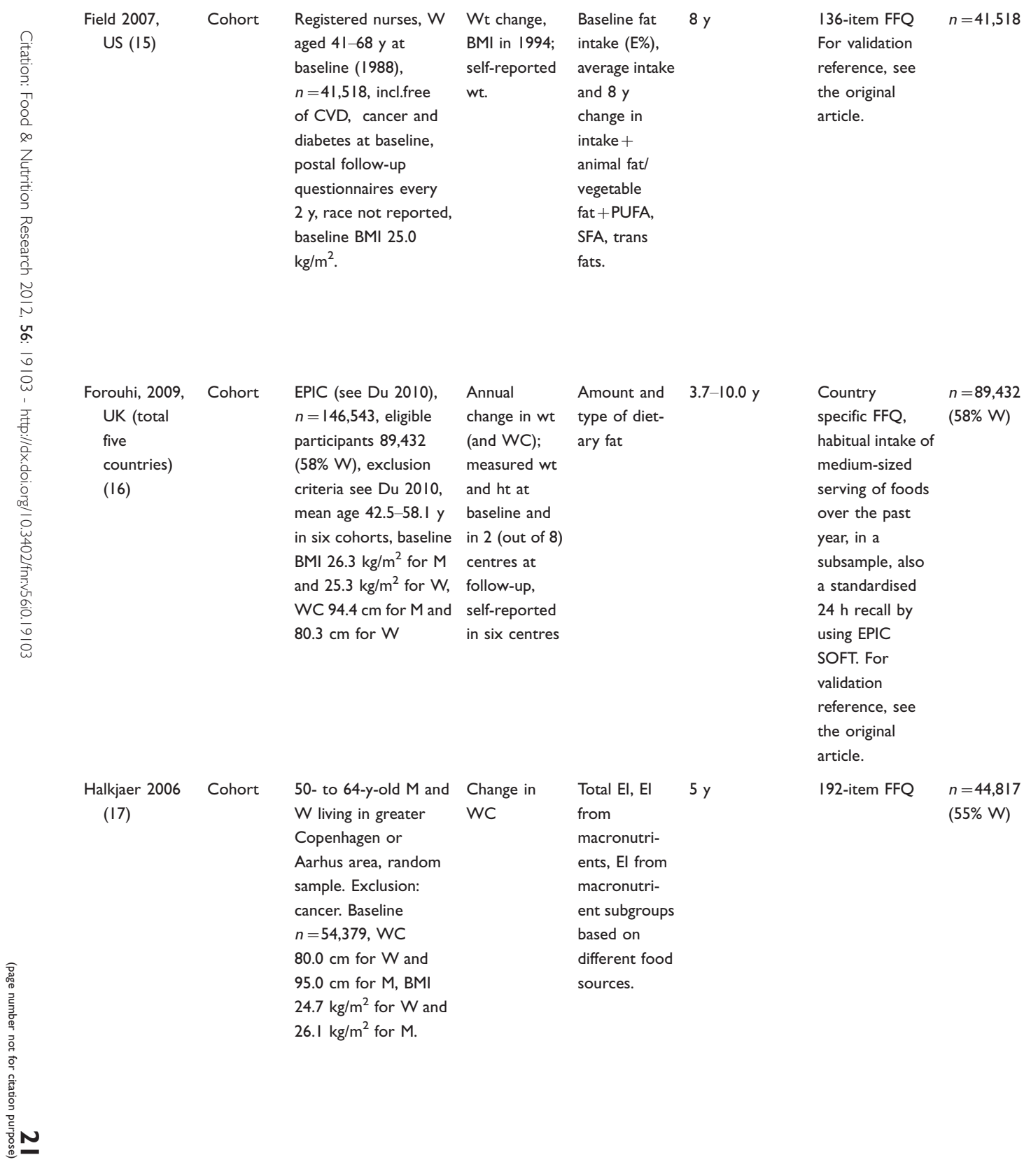

\begin{tabular}{|c|c|c|c|}
\hline $\begin{array}{l}8 y \text {. Drop out } \\
\text { rates, or } \\
\text { number of } \\
\text { subjects that } \\
\text { were excluded } \\
\text { not reported. }\end{array}$ & $\begin{array}{l}\text { beta for } 1 \% \text { difference } \\
\text { (substituting } 1 \% \text { of } \\
\text { calories from fat for } \\
1 \% \text { of calories from } \\
\text { CHD) baseline fat } \\
\text { intake } B=0.1 \text { I } \\
(p<0.0001) \text {, PUFA } \\
0.42 \text {, SFA } 0.40 \text { and } \\
\text { TFA } 0.54 \text {. }\end{array}$ & $\begin{array}{l}\text { Baseline BMI, } \\
\text { age, PA, time } \\
\text { spent sitting, } \\
\text { smoking, } \\
\text { menopausal } \\
\text { status and } \\
\text { protein\%. }\end{array}$ & $\begin{array}{l}\text { B } \\
\text { Number of } \\
\text { subjects } 1 / 3 \\
\text { of the original } \\
\text { sample } \\
\text { (1976), no } \\
\text { data on } \\
\text { representa- } \\
\text { tiveness of } \\
\text { the data, } \\
\text { dietary } \\
\text { assessment } \\
\text { methods } \\
\text { poorly } \\
\text { described. }\end{array}$ \\
\hline $\begin{array}{l}3.7-10.0 \text { y. No } \\
\text { follow-up data } \\
\text { available }\end{array}$ & $\begin{array}{l}\text { Weight change } 0.90 \mathrm{~g} / \mathrm{y} \\
\text { (95\% Cl: }-0.54 \text { to } \\
2.34 \text { ) for men and } \\
-1.30 \mathrm{~g} / \mathrm{y} \text { ( }-3.70 \text { to } \\
\mathrm{I} .1 \mathrm{I}) \text { for women per I } \\
\mathrm{g} / \text { day energy-adjusted } \\
\text { fat intake, a null } \\
\text { association for PUFA; } \\
\text { MUFA; WC and fat: no } \\
\text { significant associations } \\
\text { between any fat type } \\
\text { and wt change }\end{array}$ & $\begin{array}{l}\text { baseline wt and } \\
\text { ht, El follow-up } \\
\text { period, PA, } \\
\text { smoking, } \\
\text { education, } \\
\text { alcohol, protein }\end{array}$ & B \\
\hline $\begin{array}{l}5 \text { y. Drop out } \\
\text { rate } 17.4 \% \text {. }\end{array}$ & $\begin{array}{l}\text { Neither total El nor EI } \\
\text { from each of the } \\
\text { macronutrients was } \\
\text { associated with } \\
\text { changes in WC, } \\
\text { except for an inverse } \\
\text { association with } \\
\text { protein, especially } \\
\text { animal protein. In } \\
\text { women, positive } \\
\text { associations with } \\
\text { changes in WC were } \\
\text { seen for CHD from } \\
\text { refined grains and po- } \\
\text { tatoes and from foods } \\
\text { with simple } \\
\text { sugars. whereas }\end{array}$ & $\begin{array}{l}\text { Baseline WC, } \\
\text { BMI, age, } \\
\text { smoking, } \\
\text { alcohol, sporting } \\
\text { activity, other } \\
\text { macronutrients } \\
\text { than the one } \\
\text { analyzed, energy } \\
\text { intake. }\end{array}$ & $\begin{array}{l}\text { B } \\
\text { Follow-up wt } \\
\text { and WC were } \\
\text { self-reported. } \\
\text { Power not } \\
\text { reported, but } \\
\text { apparently } \\
\text { adequate. }\end{array}$ \\
\hline
\end{tabular}




\begin{tabular}{|c|c|c|c|c|c|c|c|c|c|c|c|c|}
\hline $\begin{array}{l}\text { Howard, 2006, } \\
\text { US (I8) }\end{array}$ & $\begin{array}{l}\mathrm{RCT} \\
\text { (interven- } \\
\text { tion, trial) }\end{array}$ & $\begin{array}{l}n=56,139 \text { that } \\
\text { provided consent and } \\
\text { met }>32 \mathrm{E} \% \text { of fat } \\
\text { criterion, of that } 7,304 \\
\text { were excluded (e.g. } \\
\text { nutritionist judgement, } \\
\text { medical condition, } \\
\text { eating out), } n=48,835 \\
\text { that were randomised } \\
\text { to intervention } \\
(n=19,54 \mathrm{I}) \text { and con- } \\
\text { trol }(n=29,294) \text {, aged } \\
50-79 \mathrm{y} . \text { Mixed race } \\
\text { reflecting the } \\
\text { characteristics of the } \\
\text { general population in } \\
\text { US, (non-Hispanic } \\
\text { white analysed } \\
\text { separately).Baseline } \\
\text { BMI } 29.1 \mathrm{~kg} / \mathrm{m}^{2} \text { and } \\
\text { WC } 89.0 \mathrm{~cm} \text { in both } \\
\text { groups }(\mathrm{I} \text { and C). }\end{array}$ & $\begin{array}{l}\text { Mean wt } \\
\text { change across } \\
\text { follow-up; } \\
\text { measured wt, } \\
\text { ht, waist and } \\
\text { hip. }\end{array}$ & $\begin{array}{l}\text { Reduction of } \\
\text { total fat to } 20 \\
\text { E\% and } \\
\text { increase of } \\
\text { vegetable and } \\
\text { fruit intake to } \\
\text { five or more } \\
\text { servings and } \\
\text { grains six or } \\
\text { more servings } \\
\text { daily. }\end{array}$ & $\begin{array}{l}\text { Mean follow-up } \\
7.5 \text { y, } \\
\text { randomisation } \\
\text { between } \\
\text { 1993-1998, } \\
\text { anthropometric } \\
\text { and nutrition } \\
\text { data until } \\
\text { August } 2004 \text {. }\end{array}$ & $\begin{array}{l}\text { Women's Health } \\
\text { Initiative FFQ at } \\
\text { baseline and I } \\
\text { y+every } 3 \text { y. }\end{array}$ & $\begin{array}{l}n=14,246 \text { for } \\
\text { lon and } \\
n=22,083 \\
\text { for } C\end{array}$ & $\begin{array}{l}\text { See Carty } \\
2010 \text { for } \\
\text { intervention; } \\
\text { baseline } 38.8 \\
\text { E\% from fat in } \\
\text { I and C, } 29.8 / \\
38.1 \text { E\% at } \\
\text { follow-up, } \\
\text { SFA: I3.6 E\% } \\
\text { at baseline, } \\
\text { I0.1/13.2 E\% } \\
\text { at follow-up, } \\
\text { CHO: } 44.5 \\
\text { E\% at base- } \\
\text { line, } 52.7 / 44.7 \\
\text { E\% at follow- } \\
\text { up, fibre: } 14.4 \\
\mathrm{~g} \text { at baseline, } \\
\text { 16.9//14.4 } \mathrm{g} \text { at } \\
\text { follow-up. }\end{array}$ & $\begin{array}{l}\text { Mean follow-up } \\
7.5 \text { y; } 2,092 \\
\text { ( } 4.3 \% \text { of C } \\
\text { group, } 4.3 \% \text { of I } \\
\text { group) were } \\
\text { deceased, } \\
\text { I,309 ( } 2.5 \% \text { C, } \\
2.9 \% \text { I) stopped } \\
\text { follow-up, } 670 \\
\text { (I.2\% C, I.6\% } \\
\text { I) were lost to } \\
\text { follow-up. }\end{array}$ & $\begin{array}{l}\text { Decrease in wt } 2.2 \mathrm{~kg} \\
\text { in the I group at year I } \\
\text { and mean wt } 2.2 . \mathrm{kg} \\
\text { less than in } C \text {. A } \\
\text { significant difference } \\
\text { between I and C } \\
(0.5 \mathrm{~kg}, P=0.01) \\
\text { maintained through } \\
\text { year } 9 ; \mathrm{W} \text { with the } \\
\text { greatest reduction in } \\
\text { fat intake had the } \\
\text { argest wt loss ( } P \text { for } \\
\text { trend }<0.00 \mathrm{I} \text { both for } \\
\text { I and } C \text { ) }\end{array}$ & $\begin{array}{l}\text { Age, race, BMl at } \\
\text { baseline, change } \\
\text { in dietary intake } \\
\text { and PA patterns; } \\
\text { secondary ana- } \\
\text { lyses adjusted } \\
\text { for El. }\end{array}$ & A \\
\hline $\begin{array}{l}\text { Iqbal 2006, } \\
\text { Denmark } \\
(19)\end{array}$ & Cohort & $\begin{array}{l}\text { Danish citizens living in } \\
\text { the western part of } \\
\text { Copenhagen County, } \\
\text { recruited and } \\
\text { examined in } 1976 \\
\text { (the } 1936 \text { cohort) and } \\
1982 \text { (MONICA), } \\
\text { follow-up in 198I and } \\
\text { 1987, respectively, } \\
n=20,25 \text { M and W } \\
\text { aged } 30,40,50 \text { and } 60 \\
\text { y at baseline, exclusion } \\
\text { because of missing }\end{array}$ & $\begin{array}{l}\text { Wt change; ht } \\
\text { and wt } \\
\text { measured at } \\
\text { baseline and } \\
\text { follow-up. }\end{array}$ & $\begin{array}{l}\text { Dietary } \\
\text { components, } \\
\text { ED in } \\
\text { particular. }\end{array}$ & $5 y$ & $\begin{array}{l}\text { Weighed 7-day } \\
\text { food record at } \\
\text { baseline. No } \\
\text { data on } \\
\text { database, ED } \\
\text { calculated } \\
\text { including the } \\
\text { water content as } \\
\text { follows: energy } \\
\text { from CHO+ } \\
\text { prot +fat + } \\
\text { alcohol (MJ) } \\
\text { divided by }\end{array}$ & $\begin{array}{l}n=862 \mathrm{M} \\
\text { and } n=900 \\
\mathrm{~W} .\end{array}$ & & $\begin{array}{l}\text { Only } \\
\text { participation } \\
\text { rate reported: } \\
\geq 79 \% \text {; in that } \\
\text { case } \\
\text { assuming that } \\
\text { drop- out rate } \\
\text { must be less } \\
\text { than } 21 \% .\end{array}$ & $\begin{array}{l}\text { ED not associated with } \\
\text { wt change for either } \\
\text { sex; in } W \text {, protein } \\
\text { intake (E\%) positively } \\
(B=3.87, \text { SE I.91, } \\
P=0.04) \text { and fibre } \\
\text { intake (g) inversely } \\
(B=-22.8, S E \text { I0.6, } \\
P=0.03) \text { associated } \\
\text { with wt change in } \\
\text { crude but not in } \\
\text { adjusted ( } P=0.06 / \\
0.10) \text { analyses. }\end{array}$ & $\begin{array}{l}\text { Age, BMI, PA, } \\
\text { educational } \\
\text { level, smoking, El } \\
\text { (baseline } \\
\text { variables) }\end{array}$ & A \\
\hline
\end{tabular}


information or

extreme values,

baseline BMI 25.1

$\mathrm{kg} / \mathrm{m}^{2}$ for $M$ and

$23.4 \mathrm{~kg} / \mathrm{m}^{2}$ for $W$

\begin{tabular}{|c|c|c|c|c|}
\hline $\begin{array}{l}\text { Koh-Banerjee, } \\
\text { 2003, US } \\
(20)\end{array}$ & Cohort & $\begin{array}{l}\text { The Health } \\
\text { Professionals' } \\
\text { Follow-up Study with } \\
51,529 \text { male health } \\
\text { professionals aged } \\
40-75 \mathrm{y} \text {. At baseline in } \\
1986,17,584 \text { excluded } \\
\text { because of death or } \\
\text { medical condition, } \\
17,358 \text { because of } \\
\text { missing information, } \\
\text { final sample } 16,587, \\
\text { baseline BMI } \\
24.9-25.2 \mathrm{~kg} / \mathrm{m}^{2} \\
\text { (varied across age } \\
\text { groups). }\end{array}$ & $\begin{array}{l}\text { Change in } \\
\text { WC, } \\
\text { self- } \\
\text { reported } \\
\text { wt and ht } \\
\text { (biannual } \\
\text { question- } \\
\text { naires), } \\
\text { self-reported } \\
\text { WC with a } \\
\text { sent tape } \\
\text { measure in } \\
1987 \text { and } \\
1996 .\end{array}$ & $\begin{array}{l}\text { Changes in } \\
\text { diet and } \\
\text { macronutri- } \\
\text { ents }\end{array}$ \\
\hline
\end{tabular}

Liu, 2003, US Cohort

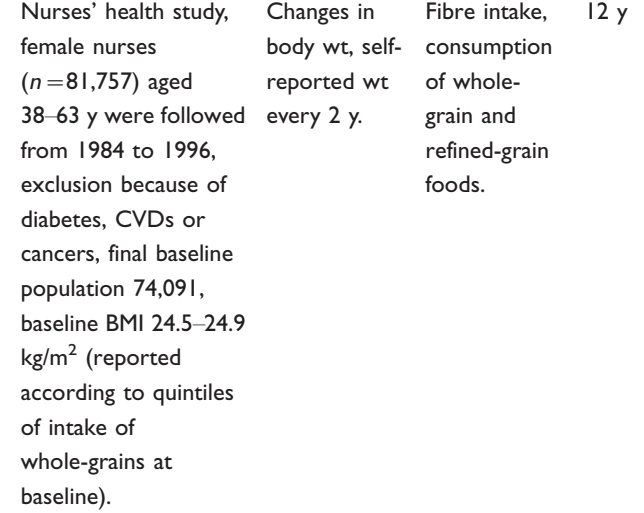

weight of

$\mathrm{CHO}+$ prot +

fat + alcohol +

fibre + ash +

water (g)

|3|-item, semi- $\quad n=16,587 \mathrm{M}$

quantitative $\mathrm{FFQ}$

to assess typical

food intake over

the previous

year, collected in

1986, 1990 and

1994. US Dept

of Agriculture,

Composition of

foods - raw,

processed and

prepared

1963-1988.

Validated among

a subset of the

study

participants. See

the original

article for the

literature

reference.

|26-item semi- $\quad n=74,09$ |

quantitative FFQ

1984, 1986

1990 and 1994

(average

consumption

during the

previous year).

No information

original article

for the validation

literature

reference.

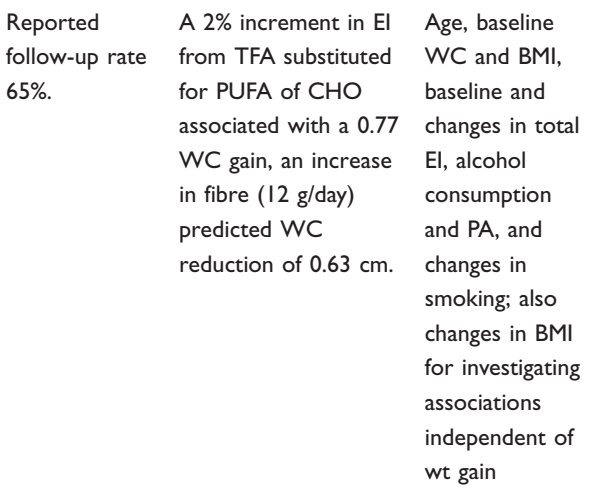

Drop-out rates Increase in whole grain Age, $y$ of follow- B

not reported. intake (average wt gain up, change in PA, The number in $2-4$ y $1.23+0.02 \mathrm{~kg}$ smoking status, of

in the highest and hormone participants at

$1.52 \pm 0.02 \mathrm{~kg}$ in the replacement follow-up not

lowest quintiles) and therapy, intakes reported,

fibre intake $(0.97 \pm$ of alcohol, physical

$0.02 \mathrm{~kg}$ and $\mathrm{I} .73 \pm 0.02$ caffeine and activity level

$\mathrm{kg}$ respectively) total El. information

associated with less wt from year

gain ( $p$ for trend 1982 but no

$<0.0001$ ), increase in information

refined grain intake on the

associated with great- measurement

$0.03 \mathrm{~kg}$ and $1.14 \pm 0.03$

$\mathrm{kg}, p<0.0001$ ); 12 y

follow-up: greatest

increase (the highest

quintile of change) 


\begin{tabular}{|c|c|c|c|c|c|c|c|}
\hline $\begin{array}{l}\text { Mosca, } 200 \\
\text { US (22) }\end{array}$ & Cohort & $\begin{array}{l}\text { A geographically based } \\
\text { (San Luis Valley, } \\
\text { Colorado) sample } \\
(n=1,35 \mathrm{I}) \text { aged } \\
20-74 \mathrm{y} \text {, no history of } \\
\text { diabetes, only subjects } \\
\text { with normal glucose } \\
\text { tolerance included } \\
(n=1,027) \text {, exclusions } \\
\text { during follow-up } \\
\text { because of type } 2 \\
\text { diabetes/IGT/IFG, } \\
\text { pregnancy, change in } \\
\text { smoking status, total } \\
n=782 \text { at baseline: } \\
\text { non-Hispanic white } \\
\mathrm{M}(n=213) \text { and } \mathrm{W} \\
(n=267), \text { Hispanic } \mathrm{M} \\
(n=136) \text { and } \mathrm{W} \\
(n=166) \text {, baseline BMI } \\
25.7 \mathrm{~kg} / \mathrm{m}^{2} \text { for } \mathrm{M} \text { and } \\
24.3 \mathrm{~kg} / \mathrm{m}^{2} \text { for } \mathrm{W} \text {. }\end{array}$ & $\begin{array}{l}\text { Wt change, } \\
\text { measured wt } \\
\text { and ht }\end{array}$ & $\begin{array}{l}\text { Energy from } \\
\text { fat }(E \%)\end{array}$ & $11.2 \mathrm{y}$ & $\begin{array}{l}\text { 24-h recall } \\
\text { Nutrition } \\
\text { Coordinating } \\
\text { Center's } \\
\text { nutrient } \\
\text { database at } \\
\text { University of } \\
\text { Minnesota, } \\
\text { version } 14 \\
(1987)\end{array}$ & $\begin{array}{l}n=782 \text { at } \\
\text { baseline }\end{array}$ \\
\hline $\begin{array}{l}\text { Romaguera, } \\
2010, \\
\text { Europe (23) }\end{array}$ & Cohort & $\begin{array}{l}\text { EPIC participants who } \\
\text { were involved in } \\
\text { DiOGenes - project, } \\
\text { eight centres from five } \\
\text { countries (Italy, } \\
\text { Netherlands, } \\
\text { Germany, Denmark, } \\
\text { UK). Exclusion: } \\
\text { pregnancy, chronic } \\
\text { diseases, age > } 60 \text { at } \\
\text { baseline, smoking } \\
\text { status changed during } \\
\text { follow-up. Participants: } \\
\text { 19,694 M and } 28,937 \\
\text { W. These were } \\
\text { selected from 102,346 } \\
\text { participants with }\end{array}$ & $\begin{array}{l}\text { WC, adjusted } \\
\text { to BMI by } \\
\text { residuals. }\end{array}$ & $\begin{array}{l}\text { Dietary ED } \\
\text { without } \\
\text { drinks, Gl and } \\
\text { GL. }\end{array}$ & $\begin{array}{l}\text { Median follow- } \\
\text { up } 5.5 \mathrm{y}\end{array}$ & $\begin{array}{l}\text { Country-specific } \\
\text { FFQ. National } \\
\text { food } \\
\text { composition } \\
\text { tables. ED was } \\
\text { calculated from } \\
\text { solid, semi-solid } \\
\text { and liquid foods, } \\
\text { but not from } \\
\text { drinks. Gl } \\
\text { database was } \\
\text { specially } \\
\text { developed using } \\
\text { mainly published } \\
\text { information. } \\
\text { FFQ validation } \\
\text { has been }\end{array}$ & $\begin{array}{l}n=19,694 \mathrm{M} \\
\text { and } \\
n=28,937 \mathrm{~W} .\end{array}$ \\
\hline
\end{tabular}


results on both

baseline and follow-up.

Savage, 2008, Cohort US (24)

Sherwood,

2000, Us

(25)

Rando- Participants for the trial, but study recruited by data direct mailing,

$W(n=192)$ living in change, wt $\mathrm{kcal} / \mathrm{g}$;

Pennsylvania recruited and ht excluding

as part of a longitudinal measured at beverages.

each occasion

examine parental $\quad(4 \times, 2 y$

criteria focused on

daughters'

characteristics, none

for mothers

( = participants),

exclusions because of

missing data on wt,

final sample $(n=186)$,

age range $24.1-48.8 y$

at baseline, baseline

BMI $26.9 \mathrm{~kg} / \mathrm{m}^{2}$

analysed newspaper and radio

as a ads etc, free of majo

cohort.

chronic diseases,

aged $20-45 y$,

predominantly white.

Data derived from

$826 \mathrm{~W}$ and $218 \mathrm{M}$

( $93 \%$ of total sample

enrolled at baseline)

who completed the

baseline and at least

one of the 3 annual

follow-up assessments,

baseline BMI $28.0 \mathrm{~kg} /$

$\mathrm{m}^{2}$ for $M$ and $26.8 \mathrm{~kg} /$

$\mathrm{m}^{2}$ for $W$. (see the original

article for the

literature

reference)

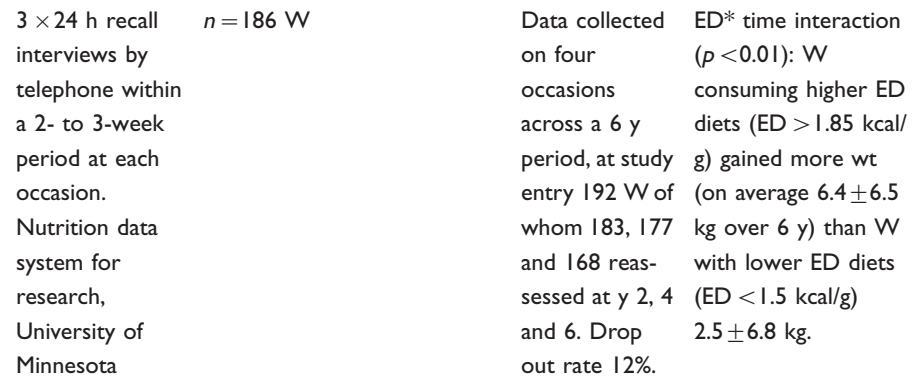

(Gl), fibre, fat,

protein and $\mathrm{E}$

(GL), $\mathrm{Gl}$ and

macronutrients

(fibre).

Initial BMI,

dietary fibre PA not

intake, caloric assessed at

beverage intake all, analyses

not adjusted

for age, total

$\mathrm{El}$, fat $\mathrm{E} \%$ and

$\mathrm{CHO} \%$

varied across

ED groups.

\begin{tabular}{|c|c|c|c|c|c|c|c|c|c|}
\hline $\begin{array}{l}\text { Wt change, } \\
\text { body wt and } \\
\text { ht measured } \\
\text { at baseline } \\
\text { and annually. }\end{array}$ & $\begin{array}{l}\text { Macronutri- } \\
\text { ent intake } \\
\text { (and PA); } \\
\text { total El, E\% } \\
\text { from fat and } \\
\text { from } \\
\text { alcoholic } \\
\text { beverages } \\
\text { presented in } \\
\text { this paper. }\end{array}$ & $3 y$ & $\begin{array}{l}\text { 60-item version } \\
\text { of Block FFQ to } \\
\text { estimate usual } \\
\text { dietary intake } \\
\text { during the past } y \text {. } \\
\text { Validation has } \\
\text { been reported } \\
\text { earlier (see the } \\
\text { original article } \\
\text { for the literature } \\
\text { reference) }\end{array}$ & $\begin{array}{l}n=826 \mathrm{~W} \\
n=218 \mathrm{M}\end{array}$ & $\begin{array}{l}\text { Participants } \\
\text { randomised } \\
\text { to one of two } \\
\text { mail-based } \\
\text { educational } \\
\text { programs or } \\
\text { to a no- } \\
\text { contact } \\
\text { control } \\
\text { group; } \\
\text { however, in } \\
\text { this paper } \\
\text { data analyses } \\
\text { as one } \\
\text { cohort, in } \\
\text { analyses } \\
\text { subjects were } \\
\text { divided in } \\
\text { weight } \\
\text { gainers ( }>5 \\
\text { lb wt gain), wt } \\
\text { maintainers }\end{array}$ & $\begin{array}{l}826 \mathrm{~W}, 218 \mathrm{M} \\
\text { at baseline, } 759 \\
\mathrm{~W} \text { and } 198 \mathrm{M} \\
\text { at } \mathrm{y} 3 .\end{array}$ & $\begin{array}{l}\text { Increases in E\% from } \\
\text { fat associated with in- } \\
\text { creases in body wt } \\
\text { (coefficient } 0.068, \mathrm{SE} \\
0.034, p=0.045 \text { in } \mathrm{M} \\
\text { and coeff. } 0.028, \mathrm{SE} \\
0.014, p=0.042 \text { in W); } \\
\text { no sign differences in } \\
\text { mean changes in diet- } \\
\text { ary intake across wt } \\
\text { change status (loser, } \\
\text { gainer, maintainer). }\end{array}$ & $\begin{array}{l}\text { Age, smoking } \\
\text { status, treat- } \\
\text { ment group, } \\
\text { baseline wt (and } \\
\text { baseline value on } \\
\text { respective } \\
\text { dependent } \\
\text { variables). }\end{array}$ & $\begin{array}{l}\text { B } \\
\text { Unable to } \\
\text { assess the } \\
\text { quality of } \\
\text { dietary } \\
\text { assessment } \\
\text { method } \\
\text { without origi- } \\
\text { nal references } \\
\text { for the } \\
\text { method. }\end{array}$ \\
\hline
\end{tabular}




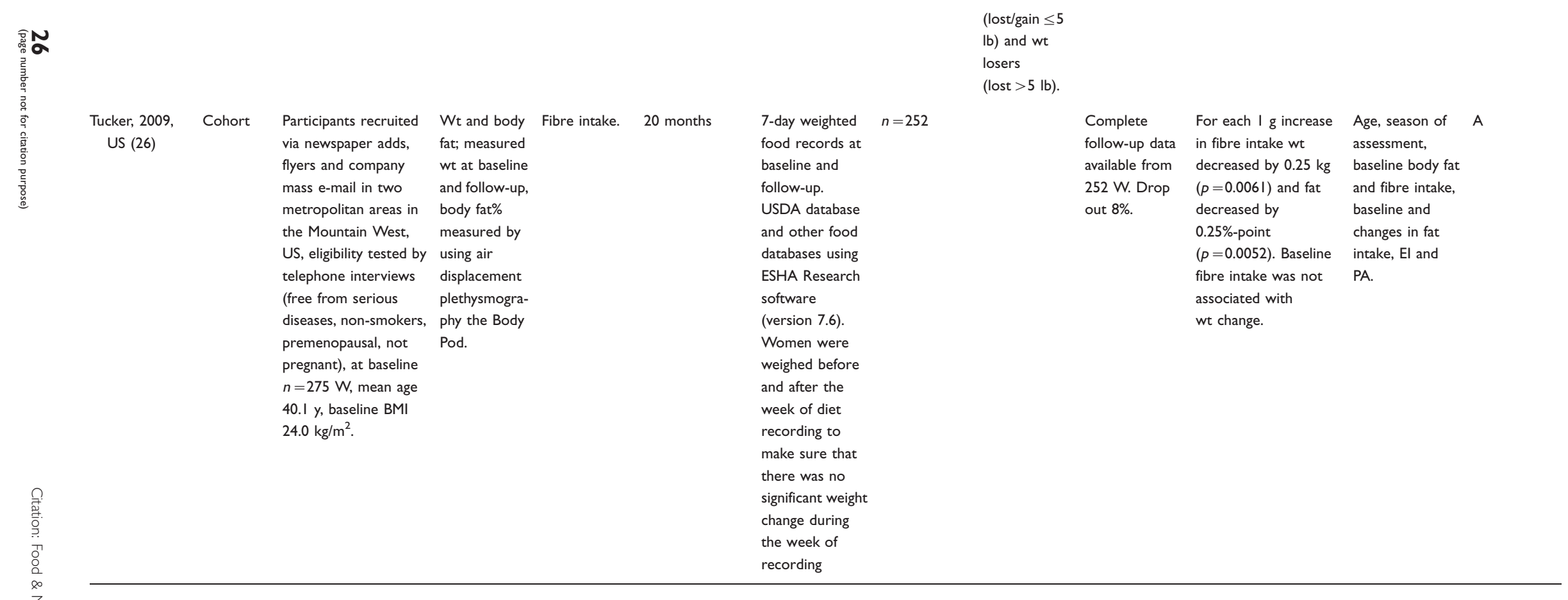

W, Women; M, Men; Wt, Weight; Ht, Height; WC, Waist circumference; PA, Physical activity; BMI, Body mass index; El, Energy intake; ED, Energy density; TFA, Trans fatty acids; CHO, Carbohydrates; MUFA, Monounsaturated fatty acids; PUFA, Poly-unsaturated fatty acids; Gl, Glycemic index; GL, Glycemic load; Y, Years. 


\section{Appendix 4 \\ Evidence tables}

Table 2. Foods and prevention of weight gain

\begin{tabular}{|c|c|c|c|c|c|c|c|c|c|c|c|c|}
\hline $\begin{array}{l}\text { Reference } \\
\text { details, First } \\
\text { author, Year, } \\
\text { Country }\end{array}$ & $\begin{array}{l}\text { Study } \\
\text { design } \\
\text { (RCT, CT, } \\
\text { cohort, } \\
\text { case con- } \\
\text { trol etc.) }\end{array}$ & $\begin{array}{l}\text { Population, subject } \\
\text { characteristics, } \\
\text { Inclusion/exclusion } \\
\text { criteria, Setting, No } \\
\text { at baseline, Male/ } \\
\text { Female, Age, } \\
\text { Ethnicity of the } \\
\text { subjects, } \\
\text { Anthropometry, } \\
\text { Location }\end{array}$ & $\begin{array}{l}\text { Outcome } \\
\text { measures } \\
\text { Disease, } \\
\text { biological } \\
\text { measures }\end{array}$ & $\begin{array}{l}\text { Intervention/ } \\
\text { exposure }\end{array}$ & $\begin{array}{l}\text { Time between } \\
\text { baseline } \\
\text { exposure and } \\
\text { outcome } \\
\text { assessment }\end{array}$ & $\begin{array}{l}\text { Dietary } \\
\text { assessment } \\
\text { method } \\
\text { FFQ, food } \\
\text { record Internal } \\
\text { validation }(\mathrm{y} / \mathrm{n})\end{array}$ & $\begin{array}{l}\text { No of subjects } \\
\text { analysed }\end{array}$ & $\begin{array}{l}\text { Intervention (I) } \\
\text { (dose interval, } \\
\text { duration) } \\
\text { Control (C) } \\
\text { (active, } \\
\text { placebo, usual } \\
\text { care etc), } \\
\text { compliance, } \\
\text { achieved } \\
\text { dietary change, } \\
\text { adherence to } \\
\text { dietary targets, } \\
\text { actual dietary } \\
\text { change }\end{array}$ & $\begin{array}{l}\text { Follow-up } \\
\text { period, } \\
\text { drop-out rate } \\
\text { (from baseline } \\
\text { to follow-up, } \\
\text { or from end of } \\
\text { intervention to } \\
\text { follow-up) } \\
\text { Drop out (\%) }\end{array}$ & $\begin{array}{l}\text { Results (I, C) } \\
\text { (Absolute } \\
\text { difference, RR, OR, } \\
p \text {-value, confidence } \\
\text { interval, sensitivity, } \\
\text { specificity, } \\
\text { observer } \\
\text { reliability? etc) }\end{array}$ & $\begin{array}{l}\text { Confounders } \\
\text { adjusted for }\end{array}$ & $\begin{array}{l}\text { Study } \\
\text { quality and } \\
\text { relevance, } \\
\text { Comments } \\
\text { (A-C) }\end{array}$ \\
\hline $\begin{array}{l}\text { Bazzano, } 2005 \text {, } \\
\text { US (27) }\end{array}$ & Cohort & $\begin{array}{l}\text { Male physicians, } \\
40-84 \text { y in } 1982 \\
n=22,066 . \text { Free } \\
\text { of CVD, DM and } \\
\text { cancer at baseline. }\end{array}$ & $\begin{array}{l}\text { Risk of } \\
\text { overweight } \\
\text { and wt gain. }\end{array}$ & $\begin{array}{l}\text { Whole and } \\
\text { refined grain } \\
\text { breakfast } \\
\text { cereal intakes. }\end{array}$ & 8 and $13 y$ & $\begin{array}{l}\text { Semiquantita- } \\
\text { tive FFQ. }\end{array}$ & $n=|7,88|$ & & $\begin{array}{l}8 \text { and } 13 y . \\
\text { Dropout } \\
n=635 \\
\text { (illness), in } \\
\text { addition } 16.6 \% \\
\text { lack of } \\
\text { breakfast } \\
\text { cereal intake } \\
\text { information. }\end{array}$ & $\begin{array}{l}\text { RR: } 0.78(8 \mathrm{y}) \text { and } \\
0.88(13 \mathrm{y}) \mathrm{M} \text { who } \\
\text { never or rarely } \\
\text { consumed } \\
\text { breakfast cereals } \\
\text { versus those who } \\
\text { consumed }>=1 \\
\text { serving per day. } \\
\text { Consumers of } \\
\text { breakfast cereal } \\
\text { consistently } \\
\text { weighed less than } \\
\text { those who } \\
\text { consumed cereals } \\
\text { less often }(p \text { for } \\
\text { trend }=0.01) .\end{array}$ & $\begin{array}{l}\text { Age, smoking, } \\
\text { baseline BMI, } \\
\text { alcohol, PA, } \\
\text { history of } \\
\text { hypertension, } \\
\text { high cholesterol } \\
\text { and use of } \\
\text { multivitamins. } \\
\text { Also } \\
\text { adjustment to } \\
\text { fruit, vegetables } \\
\text { and dairy: no } \\
\text { change in } \\
\text { results. }\end{array}$ & $\begin{array}{l}\text { B } \\
\text { Semi } \\
\text { qualitative } \\
\text { FFQ assessed } \\
\text { a limited } \\
\text { number of } \\
\text { foods. Unable } \\
\text { to compare } \\
\text { breakfast } \\
\text { cereal intake } \\
\text { to other } \\
\text { types of } \\
\text { breakfast } \\
\text { foods or to } \\
\text { skipping } \\
\text { breakfast. }\end{array}$ \\
\hline $\begin{array}{l}\text { Bes-Rastrollo, } \\
2006 \text {, Spain } \\
\text { (28) }\end{array}$ & Cohort & $\begin{array}{l}\text { University graduates, } \\
7,194 \mathrm{M} \text { and } \mathrm{W} 37 \\
( \pm \mathrm{I}) \text { y Excl. those } \\
\text { who reported total El } \\
(<800 \text { or }>4,200 \\
\mathrm{kcal} / \mathrm{day} \text { for men and } \\
<600 \text { or } 3,500 \mathrm{kcal} / \\
\text { day for women). }\end{array}$ & $\begin{array}{l}\text { Wt change } \\
\text { (self- } \\
\text { reported). } \\
\text { Validated self- } \\
\text { report } 1.5 \% \\
\text { mean relative } \\
\text { error } \\
\text { compared to } \\
\text { objective } \\
\text { measure- } \\
\text { ment. }\end{array}$ & $\begin{array}{l}\text { Sugar- } \\
\text { sweetened } \\
\text { soft drinks } \\
\text { (SSSD) or } \\
\text { consumption } \\
\text { of hamburger, } \\
\text { pizza, and } \\
\text { sausages } \\
\text { (HPS). } \\
\text { Analyses } \\
\text { were also }\end{array}$ & $\begin{array}{l}\text { Median } 28.5 \\
\text { months. }\end{array}$ & $\begin{array}{l}\text { Semiquantita- } \\
\text { tive FFQ (136 } \\
\text { food items) } \\
\text { Validated, see } \\
\text { the original } \\
\text { article for the } \\
\text { reference. }\end{array}$ & $n=7,194$ & & $\begin{array}{l}28.5 \text { month } \\
\text { follow-up with } \\
>90 \% \\
\text { follow-up rate. }\end{array}$ & $\begin{array}{l}\text { SSSD was } \\
\text { associated with } \\
\text { wt gain only in } \\
\text { subgroup } \\
\text { assessment: those } \\
\text { who had reported } \\
\text { a previous wt gain } \\
\text { ( }>=3 \mathrm{~kg} \text {; } \\
\text { during the } 5 \text { y } \\
\text { before this study } \\
\text { baseline). }\end{array}$ & $\begin{array}{l}\text { Sex, total El } \\
\text { from non-SSD } \\
\text { sources, fibre, } \\
\text { alcohol, milk, } \\
\text { PA, smoking, } \\
\text { snacking, TV, } \\
\text { and baseline wt }\end{array}$ & $\begin{array}{l}\text { B } \\
\text { Weigh self- } \\
\text { reported. De- } \\
\text { tails of dietary } \\
\text { assessments } \\
\text { were lacking } \\
\text { in this report, } \\
\text { although they } \\
\text { have been } \\
\text { reported } \\
\text { earlier. The }\end{array}$ \\
\hline
\end{tabular}


meat and

sweetened

fruit juice.

\begin{tabular}{|c|c|c|c|c|c|c|c|}
\hline $\begin{array}{l}\text { Bes-Rastrollo, } \\
\text { 2006, Spain } \\
\text { (29) }\end{array}$ & Cohort & $\begin{array}{l}\text { University } \\
\text { graduates, } 9,000 \mathrm{M} \\
\text { and } \mathrm{W} 37( \pm 12) \text { y } \\
\text { Excl. those who } \\
\text { reported total El } \\
(<800 \text { or }>4,200 \\
\mathrm{kcal} / \text { day for men and } \\
<600 \text { or } 3,500 \mathrm{kcal} / \\
\text { day for women). }\end{array}$ & $\begin{array}{l}\text { Wt gain or } \\
\text { likelihood of } \\
\text { becoming } \\
\text { overweight/ } \\
\text { obese. }\end{array}$ & $\begin{array}{l}\text { Olive } \\
\text { oil } \\
\text { consumption. }\end{array}$ & $\begin{array}{l}\text { Median } 28.5 \\
\text { months. }\end{array}$ & $\begin{array}{l}\text { Semiquantita- } \\
\text { tive FFQ (136 } \\
\text { food items). } \\
\text { Validated, see } \\
\text { original article } \\
\text { for the } \\
\text { reference. }\end{array}$ & $n=7,368$ \\
\hline $\begin{array}{l}\text { Bes-Rastrollo } \\
\text { 2007, Spain } \\
(60)\end{array}$ & Cohort & $\begin{array}{l}\text { University } \\
\text { graduates, } 9,000 \mathrm{M} \\
\text { and } \mathrm{W} 37( \pm 12) \text { y } \\
\text { Excl. those who } \\
\text { reported total El } \\
(<800 \text { or }>4,200 \\
\mathrm{kcal} / \mathrm{day} \text { for men } \\
\text { and }<600 \text { or } 3,500\end{array}$ & $\begin{array}{l}\text { An increase in } \\
\text { body wt of at } \\
\text { least } 5 \mathrm{~kg} \\
\text { during follow- } \\
\text { up. Change in } \\
\text { body wt dur- } \\
\text { ing follow-up. }\end{array}$ & $\begin{array}{l}\text { Nut } \\
\text { consumption } \\
=\text { walnuts, } \\
\text { almonds, } \\
\text { hazelnuts, and } \\
\text { peanuts. }\end{array}$ & $\begin{array}{l}\text { Median } 28 \\
\text { months. }\end{array}$ & $\begin{array}{l}\text { Semiquantita- } \\
\text { tive FFQ (I36 } \\
\text { food items) } \\
\text { Validated, see } \\
\text { original article } \\
\text { for the } \\
\text { reference. }\end{array}$ & $n=8,865$ \\
\hline
\end{tabular}

of HPS was

associated with

higher wt gain,

independent of

consumption of

SSSD and of

previous wt gain.

Fifth compared

with the first

quintile: OR 1.2

(1.0-1.4; $p$ for

trend $=0.05$ ) Red

meat and

sweetened fruit

juice consumption

were not

significantly

associated with wt

comparability of this

population

(students

from Spain)

and Nordic

population is

not clear.

\begin{tabular}{|c|c|c|c|}
\hline $\begin{array}{l}28.5 \text { month } \\
\text { follow-up } \\
\text { with }>90 \% \\
\text { follow-up rate. }\end{array}$ & $\begin{array}{l}\text { No significant } \\
\text { association } \\
\text { between baseline } \\
\text { consumption of } \\
\text { olive oil and } \\
\text { subsequent wt } \\
\text { change, nor to the } \\
\text { risk of developing } \\
\text { overweight and } \\
\text { obesity. }\end{array}$ & $\begin{array}{l}\text { Age, sex, } \\
\text { total El, } \\
\text { vegetable } \\
\text { consumption, } \\
\text { PA, smoking, } \\
\text { snacking } \\
\text { between meals, } \\
\text { TV viewing, and } \\
\text { baseline BMI. }\end{array}$ & $\begin{array}{l}\text { B } \\
\text { Wt self- } \\
\text { reported. De- } \\
\text { tails of dietary } \\
\text { assessments } \\
\text { were lacking } \\
\text { in this report, } \\
\text { although they } \\
\text { have been } \\
\text { reported } \\
\text { earlier. The } \\
\text { comparability } \\
\text { of this } \\
\text { population } \\
\text { (students } \\
\text { from Spain) } \\
\text { and Nordic } \\
\text { population is } \\
\text { not clear. }\end{array}$ \\
\hline $\begin{array}{l}\text { Median } 28 \\
\text { months., } \\
\text { Drop-out } \\
24.3 \% .\end{array}$ & $\begin{array}{l}\text { Participants who } \\
\text { ate nuts two or } \\
\text { more times per } \\
\text { week had a } \\
\text { significantly lower } \\
\text { risk of wt gain (OR: } \\
0.69 ; 95 \% \mathrm{Cl} \text { : } \\
0.53-0.90, p \text { for }\end{array}$ & $\begin{array}{l}\text { Sex, baseline } \\
\text { BMI, PA, } \\
\text { smoking, } \\
\text { snacking, } \\
\text { television } \\
\text { watching. }\end{array}$ & $\begin{array}{l}\text { B } \\
\text { Wt self- } \\
\text { reported. De- } \\
\text { tails of dietary } \\
\text { assessments } \\
\text { were lacking } \\
\text { in this report, }\end{array}$ \\
\hline
\end{tabular}


$\mathrm{kcal} /$ day for women). overweight/

Baseline $n=|1,7| 4$. obesity

Cohort

Nurse's health study,

( \pm 4.6$)$ y Excl. at

baseline (1991) if did

not complete FFQ, if

they reported $\mathrm{EI}$

$(<500$ or $>3,500$

$\mathrm{kcal} /$ day), history of

diabetes or CVD,

cancer before 1999

(post test), pregnancy

at any time from

baseline to post test

no PA data assessed in

1991 and 1997, only

baseline data, missing

wt data.

Du 2009 (3I) Cohort

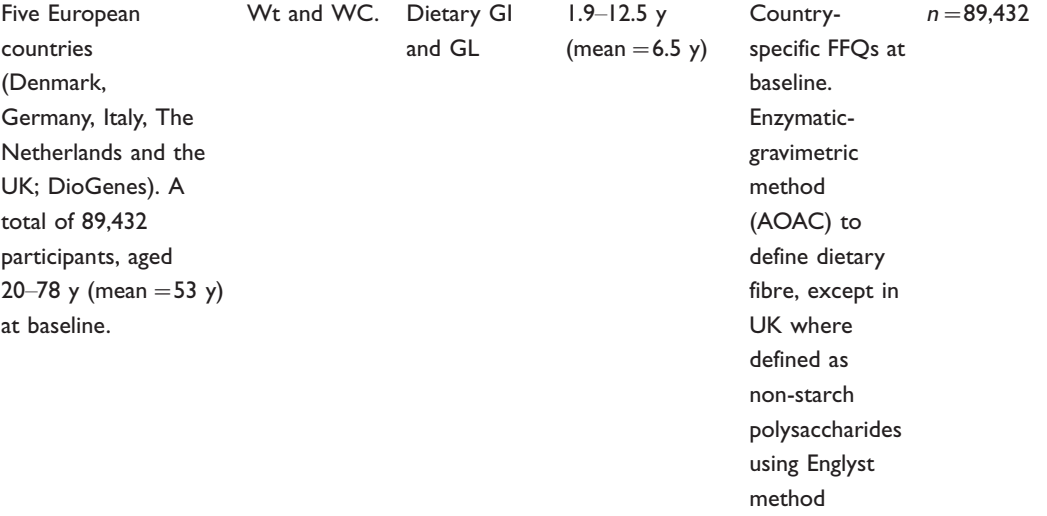

\section{trend $=0.006$ ) than}

those who never

or almost never ate

nuts. Participants

with little nut

consumption

(never/almost

never) gained an

average of 424

grams $(102,746)$

more than frequent

nut eaters.

133-item FFQ $n=51,188$

Validated, see

for the

=sum of

intakes for

reference

including

peanut

butter, and

other nuts.

8 y. Drop out

Greater nut

consumption

( $>$ or $=2$ times)

week compared

with never/almost

never) was

associated with a

slightly lower risk

of obesity (hazard

ratio: $0.77 ; 95 \%$

Cl: $0.57-1.02 ; p$

for trend $=0.003$ ).

Age, alcohol,

PA, smoking, Wt self-

postmenopau- reported.

sal hormone Details of

use, oral dietary

contraceptives, assessments

baseline BMI, were lacking

$\mathrm{GL}$, intakes of in this report,

several dietary although they

components at have been

reported

earlier. The

comparability

of this

population

(nurses from

the US) and

Nordic

population is

not clear

Median With every 10-unit Baseline

follow-up $6.5 y$ higher in $\mathrm{Gl}$, wt (range: 1.9 to increased by $34 \mathrm{~g} / \mathrm{y}$ rics,

methods to

115) and WC and lifestyle

and WC

increased by 0.19 factors, follow- (partly self-

$\mathrm{cm} / \mathrm{y}(0.11,0.27)$. up duration and assessed or

With every 50-unit other dietary reported,

higher in $\mathrm{GL}$, wt factors. variation

increased by $10 \mathrm{~g} / \mathrm{y}$ between the

$(-65,85)$ and WC centres),

increased by 0.06 drop-out

$\mathrm{cm} / \mathrm{y}(-0.01$,

exceeding 


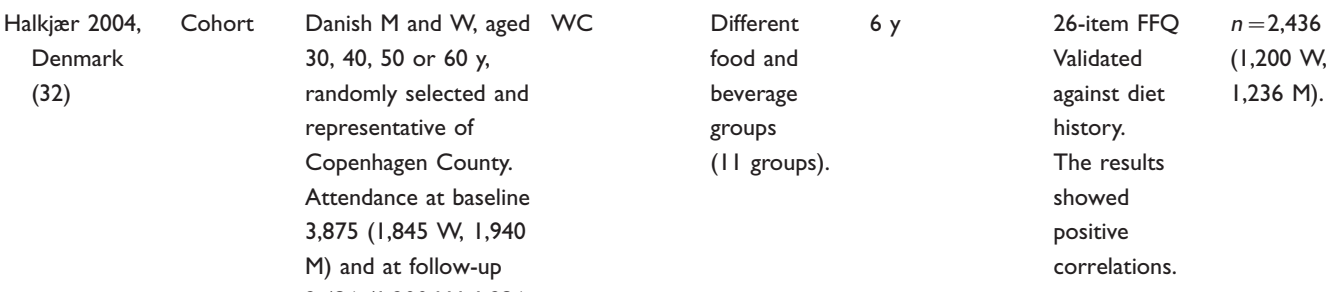

$2436(1,200 \mathrm{~W}, 1,236$

M). Median BMl at

baseline $25.2 \mathrm{~kg} / \mathrm{m}^{2}$ in

$M$ and $23.5 \mathrm{~kg} / \mathrm{m}^{2}$ in W.

Halkjær, 2009, Cohort Denmark

All $M$ and $W$ (in
Copenhagen and Whanges in
Aarhus) aged $50-64$ y
invited with no
previous history of
cancer. $35 \%$ ( $n=$
$57,053)$ of the invited
participated. In
addition 547 were
excl. because of
newly

$\begin{array}{llll}\begin{array}{l}\text { Different } \\ \text { food and }\end{array} & 5 \text { y } & 192 \text { semi- } & n=42,696 \\ \text { beverage } & & \text { quantitative } & (22,570 \mathrm{~W}) \\ \text { groups } & & \text { FFQ. } & \\ \text { (21 groups) } & \text { Validated } & \\ & & \text { against two } & \\ & & \text { 7-day weight } \\ & \text { diet records. }\end{array}$

\begin{tabular}{|c|c|c|c|}
\hline $\begin{array}{l}6 y \text {. Drop } \\
\text { out } 36 \%\end{array}$ & $\begin{array}{l}\text { Intake of refined } \\
\text { bread was } \\
\text { positively } \\
\text { associated with } \\
\text { change in WC, } \\
\text { with }(\beta=0.29 \\
(95 \% \mathrm{Cl} \text { : } \\
0.07-0.5 \mathrm{I}) \text { or } \\
\text { without ( } \beta=0.42 \text {, } \\
95 \% \mathrm{Cl}: 0.1 \mathrm{I}-0.73) \\
\text { further adjustment } \\
\text { for BMI. Spread on } \\
\text { bread, milk and } \\
\text { cheese, meat, fish, } \\
\text { potatoes, rice, } \\
\text { pasta, wholegrain } \\
\text { bread, fruits and } \\
\text { vegetables, cakes } \\
\text { and chocolate } \\
\text { were not related to } \\
\text { WC. }\end{array}$ & $\begin{array}{l}\text { Age, other food } \\
\text { groups than, } \\
\text { education, PA, } \\
\text { smoking, } \\
\text { alcohol. }\end{array}$ & $\begin{array}{l}\text { B } \\
\text { Food } \\
\text { consumption } \\
\text { was assessed } \\
\text { with a very } \\
\text { short } \\
\text { questionnaire } \\
\text { Validity was } \\
\text { only briefly } \\
\text { described. } \\
\text { The statistica } \\
\text { power was } \\
\text { not reported. }\end{array}$ \\
\hline $\begin{array}{l}\text { Drop out from } \\
\text { baseline } 24.5 \% .\end{array}$ & $\begin{array}{l}\text { The } \beta \text {-coefficients } \\
(95 \% \mathrm{Cl}) \text { were } \\
\text { assessed against } 60 \\
\text { kcal of each food } \\
\text { item. Both } \mathrm{M} \text { and } \\
\mathrm{W}: \text { Red meat } \\
\text { (inverse: } \mathrm{W}:-0.13 \text {, } \\
95 \% \mathrm{Cl}:-0.24 \text { to } \\
-0.03 \text {; } \mathrm{M}:-0.06 \text {, } \\
95 \% \mathrm{Cl}:-0.1 \mathrm{l} \text { to }\end{array}$ & $\begin{array}{l}\text { Baseline WC, } \\
\text { BMI, age, } \\
\text { smoking, PA, } \\
\text { alcohol, El per } \\
\text { day from the 2I } \\
\text { food and } \\
\text { beverage } \\
\text { groups. }\end{array}$ & $\begin{array}{l}\text { B Follow-up } \\
\text { weight was } \\
\text { self-reported. } \\
\text { Drop-out } \\
\text { exceeded } \\
20 \% .\end{array}$ \\
\hline
\end{tabular}


diagnosed cancer.

Between follow-up and

baseline 1,692 died,

435 emigrated, giving

54,379

participants for

invitation to

follow-up.

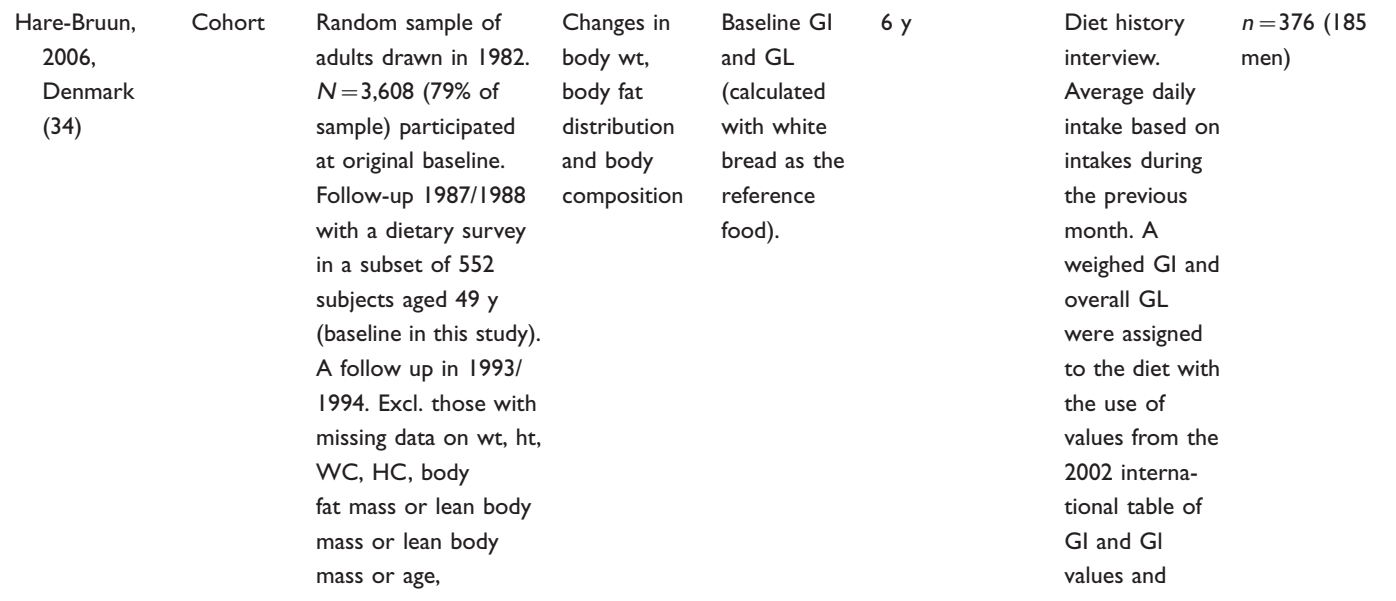

$-0.003)$, fruit

(inverse: $\mathrm{W}$ :

$-0.07,95 \% \mathrm{Cl}$ :

-0.13 to 0.004 ; $\mathrm{M}$ :

$-0.10,95 \% \mathrm{Cl}$ :

-0.15 to -0.04 )

and snack food

(positive: W: 0.06

$95 \%$ Cl: 0.003

0.1I; M: $0.09,95 \%$

Cl: $0.05-0.13$ )

significantly

associated with

WC. W only:

Inverse; vegetables

$(-0.36,95 \% \mathrm{Cl}$ :

-0.51 to -0.21 ),

high-fat dairy

$(-0.09,95 \% \mathrm{Cl}$ :

-0.15 to -0.03$)$,

butter $(-0.12$,

95\% Cl: -0.20 to

-0.04). Positive;

processed meat

(0.20, 95\% Cl:

$0.04-0.36)$,

potatoes $(0.10$

95\% Cl: 0.0006

$0.19)$, poultry

(0.19, $95 \% \mathrm{Cl}$ :

$0.01-0.37)$.

$6 \mathrm{y}$.

Positive

Baseline body B

Drop out $32 \%$.

ssociations

wh, age,

Power not

between $\mathrm{Gl}$ and smoking, years reported.

changes in body wt of education,

( $\beta$-coefficient for PA, El, E\% from

$\log$ (body weight): protein, fat and

$0.002,95 \% \mathrm{Cl}$ fibre intake.

$0.0001-0.004)$, per-

cent body fat and

WC in W only. No

associations be-

tween $\mathrm{Gl}$ for $\mathrm{M}$ and

no for GL either 


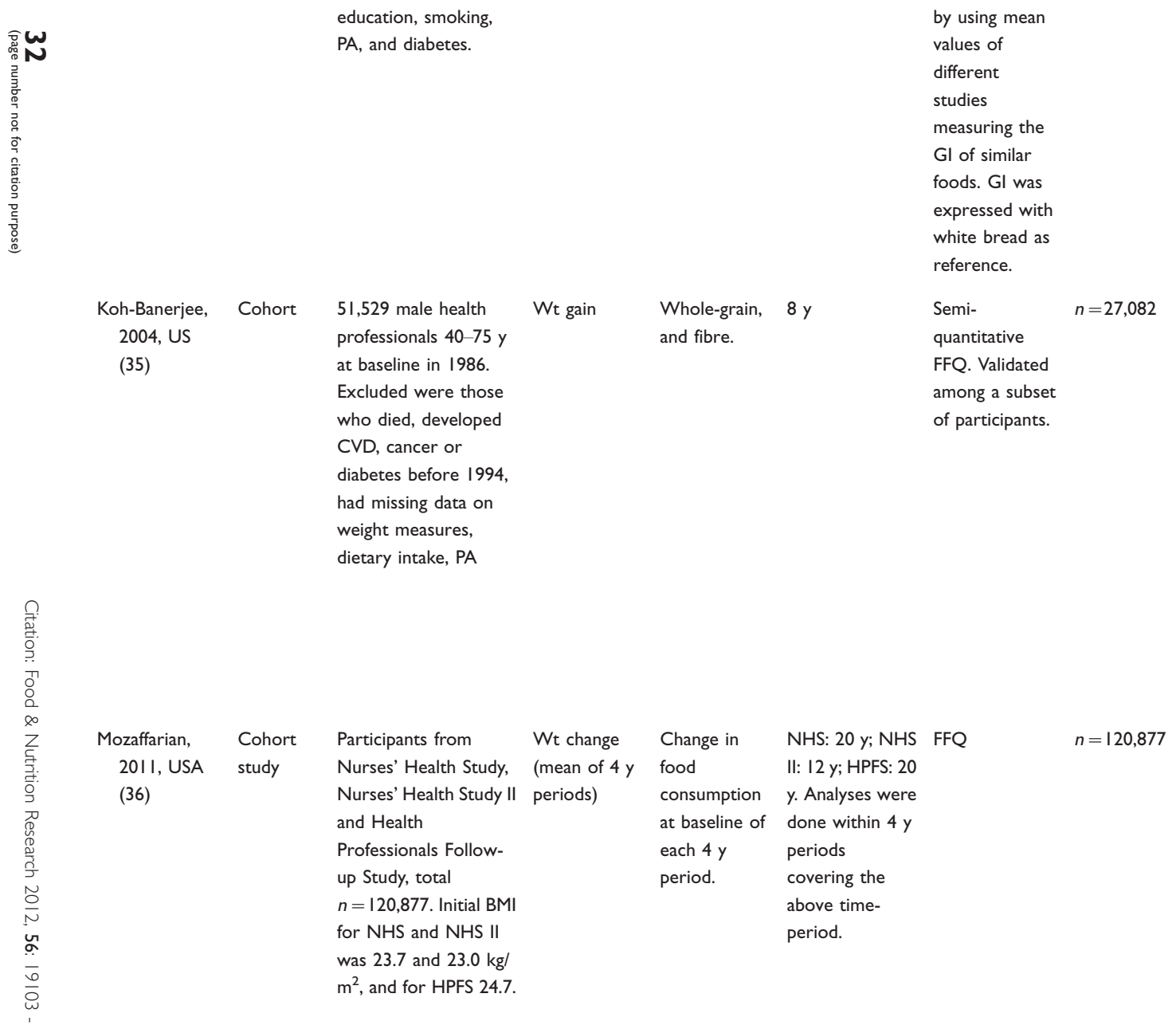

\begin{tabular}{|c|c|c|c|}
\hline $\begin{array}{l}8 \mathrm{y} . \\
\text { Drop-out } \\
47.4 \% .\end{array}$ & $\begin{array}{l}\text { Whole-grain } \\
\text { intake inversely } \\
\text { associated with wt } \\
\text { gain, with an } \\
\text { observed dose- } \\
\text { response relation. } \\
\text { For every } 40 \mathrm{~g} / \mathrm{day} \\
\text { increment in } \\
\text { whole-grain intake } \\
\text { - wt gain was } \\
\text { reduced by } 0.49 \mathrm{~kg} \text {. } \\
\text { Changes in cereal } \\
\text { and fruit fibre were } \\
\text { inversely related to } \\
\text { wt gain. }\end{array}$ & $\begin{array}{l}\text { Age, respective } \\
\text { baseline } \\
\text { exposure, } \\
\text { smoking, } \\
\text { baseline wt, and } \\
\text { baseline values } \\
\text { and changes in } \\
\text { refined grains, } \\
\text { El, PA, alcohol, } \\
\text { protein, TFA, } \\
\text { SFA, MUFA and } \\
\text { PUFA. }\end{array}$ & $\begin{array}{l}\text { B } \\
\text { Changes } \\
\text { against } \\
\text { changes. } \\
\text { Wt was self- } \\
\text { reported. }\end{array}$ \\
\hline $\begin{array}{l}\text { NHS: } 20 \text { y; } \\
\text { NHS II: } 12 \text { y; } \\
\text { HPFS: } 20 y . \\
\text { Analyses were } \\
\text { done within } 4 \text { y } \\
\text { periods } \\
\text { covering the } \\
\text { above } \\
\text { time-period. }\end{array}$ & $\begin{array}{l}\text { The average } 4 \text { y wt } \\
\text { gains in } \mathrm{kg} \text {, against } \\
\text { changes in servings, } \\
\text { were positively } \\
\text { associated with } \\
\text { potato chips } \\
(0.55,95 \% \mathrm{Cl} \text { : } \\
0.59-0.95) \text {, pota- } \\
\text { toes (0.58, 95\% Cl: } \\
0.39-0.77) \text {, } \\
\text { processed meats } \\
(0.42,95 \% \mathrm{Cl} \text { : } \\
0.36-0.49) \text {, } \\
\text { unprocessed meat } \\
(0.43,95 \% \mathrm{Cl} \text { : } \\
0.25-0.61), \text { butter } \\
(0.14,95 \% \mathrm{Cl} \text { : } \\
0.07-0.20), \text { sweets } \\
\text { and desserts (0.19, } \\
95 \% \mathrm{Cl}: 0.07-0.30) \text {, } \\
\text { and refined grains } \\
(0.18,95 \% \mathrm{Cl} \text { : }\end{array}$ & $\begin{array}{l}\text { Age, baseline } \\
\text { BMI, sleep } \\
\text { duration, } \\
\text { changes in } \\
\text { smoking, PA, } \\
\text { television } \\
\text { watching and } \\
\text { alcohol use. }\end{array}$ & $\begin{array}{l}\text { B } \\
\text { Self-reported } \\
\text { body wt, } \\
\text { reporting of } \\
\text { dietary } \\
\text { assessment } \\
\text { tool and } \\
\text { database } \\
\text { inadequate. }\end{array}$ \\
\hline
\end{tabular}




\begin{tabular}{|c|c|c|c|c|c|c|c|}
\hline $\begin{array}{c}\text { Poddar, 2009, } \\
\text { US (37) }\end{array}$ & Cohort & $\begin{array}{l}\text { Freshmen-level in } \\
\text { nutrition 2004. } 362 \\
\text { eligible (sex NA). } \\
N=76 \text { completed data } \\
\text { collection in } 2004 \text { and } \\
\text { 2005. Age } 19.2 \text { (SE 0.1) } \\
\text { y. }\end{array}$ & $\begin{array}{l}\text { Body wt and } \\
\text { composition } \\
\text { changes }\end{array}$ & $\begin{array}{l}\text { Total and } \\
\text { low-fat dairy } \\
\text { intake. }\end{array}$ & 6 months & $\begin{array}{l}\text { 7-day food } \\
\text { record. }\end{array}$ & $n=76(65 \mathrm{~W})$ \\
\hline
\end{tabular}

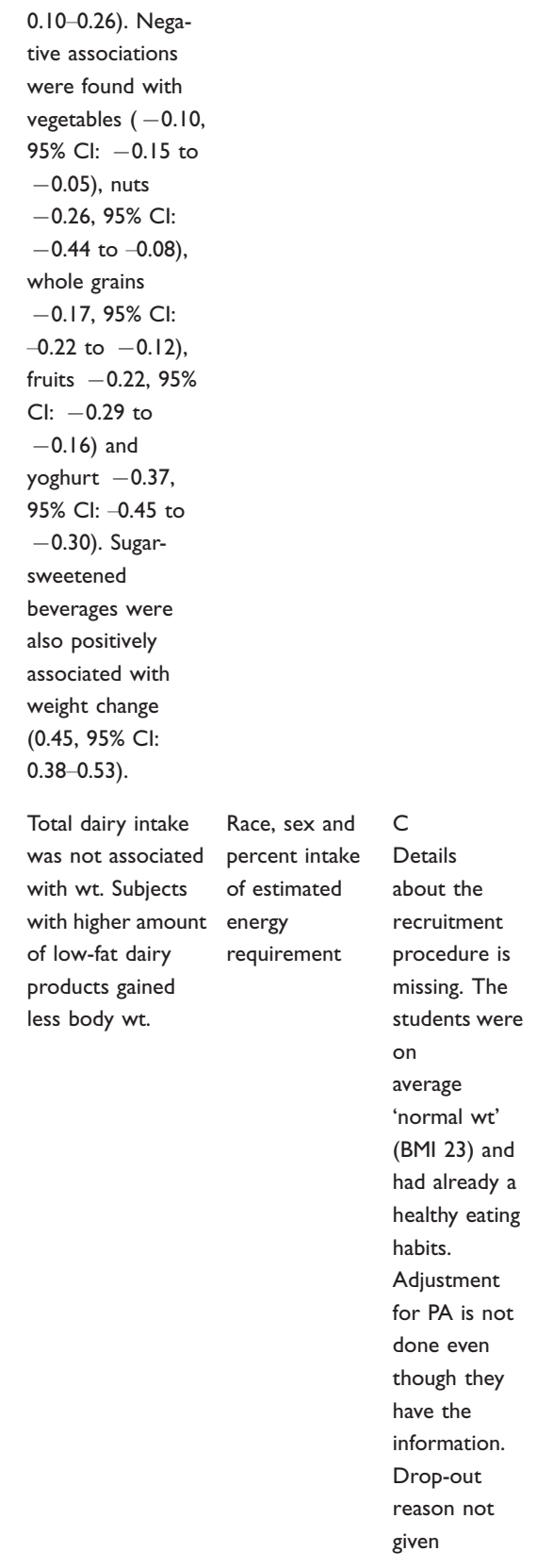




\begin{tabular}{|c|c|c|c|c|c|c|c|c|}
\hline 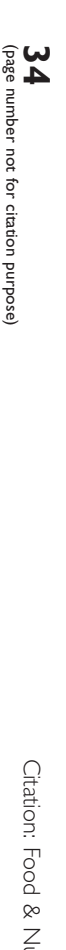 & $\begin{array}{l}\text { Rajpathak SN, } \\
2006, \text { USA } \\
(38)\end{array}$ & $\begin{array}{l}\text { Cohort } \\
\text { study }\end{array}$ & $\begin{array}{l}\text { The Health } \\
\text { professionals } \\
\text { Follow-up Study } \\
(n=51,529) \text {. M } \\
\text { subjects, } 40-75 y \text {. } \\
\text { Subjects excl. if: }<20 y \\
(n=52) \text {, } \\
\text { unreasonable El } \\
(n=1,596) \text {, cancer, } \\
\text { CVD or diabetes at } \\
\text { baseline }(n=3,57 I) \text { or } \\
\text { endpoint }(n=11,027) \text {, } \\
\text { no wt data in either } \\
\text { 1986 or 1998 } \\
(n=11,779), \text { no } \\
\text { calcium intake data in } \\
1998(n=3,889) \text {. BMI } \\
\text { at baseline } 25.1-25.3 \\
\mathrm{~kg} / \mathrm{m}^{2} \text { (across } \\
\text { quintiles). }\end{array}$ & $\begin{array}{l}12 \text { y wt } \\
\text { change (self } \\
\text { reported). }\end{array}$ & Dairy intakes & $12 y$ & $\begin{array}{l}\text { Semiquantita- } \\
\text { tive FFQ, } \\
\text { validated } \\
\text { against I week } \\
\text { diet records } \\
(n=127) \\
\text { (coefficients } \\
\text { reported, } \\
r=0.53 \text { for } \\
\text { calcium). US } \\
\text { Department of } \\
\text { Agriculture, } \\
\text { supplemented } \\
\text { with } \\
\text { information } \\
\text { from } \\
\text { manufacturers. } \\
\text { Pearson } \\
\text { correlation } \\
\text { between } \\
\text { calcium intake } \\
\text { from the FFQ } \\
\text { and the average } \\
\text { intake of two } \\
\text { I-week diet } \\
\text { records was } \\
0.53 \text {. }\end{array}$ & $\begin{array}{l}\text { Baseline dairy } \\
\text { and wt change } \\
(n=23,504)\end{array}$ \\
\hline 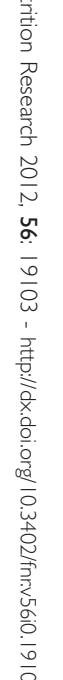 & $\begin{array}{l}\text { Romaguera } \\
2011, \\
\text { Europe (39) }\end{array}$ & Cohort & $\begin{array}{l}\text { EPIC participants who } \\
\text { were involved in } \\
\text { DiOGenes - project, } \\
\text { eight centres from five } \\
\text { countries (Italy, } \\
\text { Netherlands, Ger- } \\
\text { many, Denmark, UK). } \\
\text { Exclusion: pregnancy, } \\
\text { chronic diseases, age } \\
>60 \text { at baseline, } \\
\text { smoking status } \\
\text { changed during follow- } \\
\text { up. Participants: } \\
19,694 \text { M and } 28,937 \\
\text { W. These were } \\
\text { selected from 102,346 } \\
\text { participants with } \\
\text { results on both } \\
\text { baseline and follow-up. }\end{array}$ & $\begin{array}{l}\text { WC, adjusted } \\
\text { to BMI by } \\
\text { residuals. }\end{array}$ & $\begin{array}{l}\text { Different } \\
\text { food groups. }\end{array}$ & $\begin{array}{l}\text { Median } \\
\text { follow-up } 5.5 y \text {. }\end{array}$ & $\begin{array}{l}\text { Country- } \\
\text { specific FFQ. }\end{array}$ & $\begin{array}{l}n=19,694 \mathrm{M} \\
\text { and } n=28,937 \\
\mathrm{~W} \text {, total } \\
n=48,63 \mathrm{I} .\end{array}$ \\
\hline
\end{tabular}




\begin{tabular}{|c|c|c|c|c|c|c|c|}
\hline $\begin{array}{l}\text { Rosell, 2006, } \\
\text { Sweden (4I) }\end{array}$ & $\begin{array}{l}\text { Cohort } \\
\text { study }\end{array}$ & $\begin{array}{l}\text { Subjects from the } \\
\text { Swedish } \\
\text { Mammography Chort, } \\
\text { Västmanland and } \\
\text { Uppsala. W born } \\
\text { 1914-1948, recruited } \\
\text { in 1987-1990. Original } \\
\text { sample of } 90,069.74 \% \\
\text { had dietary info } \\
\text { ( } n=66,651) \text {. Follow } \\
\text { up in } 1997 \text {, excl. those } \\
\text { who moved away, } \\
\text { resulting in } n=56,030 \\
\text { Of those } 38,984 \\
\text { completed a FFQ. For } \\
\text { the current study } \\
\text { subjects were excl. if } \\
\text { data on body wt or ht } \\
\text { were missing at } \\
\text { baseline or follow up } \\
(n=1,783), \text { had a } \\
\text { disease }(n=8,643) \text { and } \\
\text { extreme changes in } \\
\text { BMI ( } n=12) \text {. Cohort } \\
\text { was restricted to W } \\
\text { aged } 40-55 \text { at baseline } \\
\text { BMI } 23.7 \mathrm{~kg} / \mathrm{m}^{2} \text { at } \\
\text { baseline. }\end{array}$ & $\begin{array}{l}\text { Annual wt } \\
\text { change during } \\
\text { follow up. }\end{array}$ & $\begin{array}{l}\text { Dairy food } \\
\text { consumption. }\end{array}$ & $9 y$. & $\begin{array}{l}\text { 67-item FFQ in } \\
\text { 1987. A 96- } \\
\text { item FFQ was } \\
\text { used in 1997, } \\
\text { and the fre- } \\
\text { quency of dairy } \\
\text { products during } \\
\text { the previous } \\
\text { years was as- } \\
\text { sessed by open } \\
\text { ended ques- } \\
\text { tions request- } \\
\text { ing participants } \\
\text { to report the } \\
\text { number of ser- } \\
\text { vings per day or } \\
\text { week. Valida- } \\
\text { tion against I } \\
\text { week diet re- } \\
\text { cords ( } n=129 \text { ), } \\
\text { coefficients for } \\
\text { dairy ranged } \\
\text { from } 0.33-0.64 \text {. }\end{array}$ & $n=19,352$ \\
\hline $\begin{array}{l}\text { Rosell M, 2006, } \\
\text { UK (40) }\end{array}$ & $\begin{array}{l}\text { Cohort } \\
\text { study }\end{array}$ & $\begin{array}{l}\text { Subjects from the } \\
\text { EPIC-Oxford ( } n= \\
65,500) \text {. Age } \geq 20 \text { y M } \\
\text { and } \mathrm{W} \text {. The aim was to } \\
\text { recruit participants } \\
\text { with a wide range of } \\
\text { diets by targeting } \\
\text { vegetarians and vegans }\end{array}$ & $\begin{array}{l}\text { Annual wt } \\
\text { gain during } \\
\text { follow up (self } \\
\text { reported). }\end{array}$ & $\begin{array}{l}\text { Meat-eating, } \\
\text { fish-eating, } \\
\text { vegetarian } \\
\text { and vegan. }\end{array}$ & $\begin{array}{l}\text { Median follow- } \\
\text { up } 5.3 \text { y (range } \\
3.2-9.1 \text { y). }\end{array}$ & $\begin{array}{l}\text { A I30-item } \\
\text { FFQ was also } \\
\text { used to assess } \\
\text { intake in the } \\
\text { previous I2 } \\
\text { months } \\
\text { (validation not } \\
\text { reported). }\end{array}$ & $\begin{array}{l}n=21,966 \\
(n=5,373 \mathrm{M} \\
\text { and } n=16,593 \\
\text { W) }\end{array}$ \\
\hline
\end{tabular}

$(0.01,95 \% \mathrm{Cl}$

$0.01-0.02)$, pro-

cessed meat $(0.04$,

95\% Cl: 0.02-0.06),

margarine $(0.03$,

$95 \% \mathrm{Cl}: 0.01-0.05)$,

sugar and

confectionary

$(0.01,95 \% \mathrm{Cl}$ :

$0.00-0.01)$ and

soft-drinks $(0.04$

$95 \%$ Cl: $0.02-0.07)$.

Dropout 32\% Women consuming Age, ht and wt B

from baseline $\geq$ I serving/day at baseline, El rather low.

measurements whole milk and education, Self reported

(based on the sour milk or parity, intakes wt at baseline

assumption cheese at baseline at baseline: $\mathrm{El}$, and endpoint.

that the eligible and did not change fat, $\mathrm{CHO}$,

sample was their consumption protein, fibre

28,546 incl. during follow up and alcohol and

only women had decreased risk the absolute

40-55 at of mean wt gain of change in

baseline-not $\geq 1 \mathrm{~kg} / \mathrm{y}$ compared intakes of these

clear in the with those nutrients

text). consuming $<1$ during follow-

serving/day with no up, and the

change in follow up studied

(OR $0.85 ; 95 \% \mathrm{Cl}$ : categories of

$0.73-0.99$ and $O R$ change in intake

$0.7795 \% \mathrm{Cl}: 0.59$ - of the other

0.84 , respectively). dairy products.

\begin{tabular}{|c|c|c|c|}
\hline $\begin{array}{l}\text { The number of } \\
\text { subjects eligible } \\
\text { at baseline } \\
\text { (after excl.) not } \\
\text { available }\end{array}$ & $\begin{array}{l}\text { Mean annual wt } \\
\text { gain }(\mathrm{g} / \mathrm{y}) \text { was } \\
\text { lower in vegans } \\
(284 \mathrm{~g}, 95 \% \mathrm{Cl} \text { : } \\
178,390 \text { and } 303 \mathrm{~g} \text {, } \\
95 \% \mathrm{Cl}: 21 \mathrm{I}, 396 \text {, } \\
\text { in } \mathrm{M} \text { and } \mathrm{W} \text {, } \\
\text { respectively })\end{array}$ & $\begin{array}{l}\text { PA, smoking, } \\
\text { marital status, } \\
\text { current paid } \\
\text { job, age at } \\
\text { leaving school, } \\
\text { age at } \\
\text { menarche, and }\end{array}$ & $\begin{array}{l}\text { B } \\
\text { Might not be } \\
\text { representa- } \\
\text { tive to the } \\
\text { Nordic popu- } \\
\text { lation due to } \\
\text { high } \\
\text { proportion of }\end{array}$ \\
\hline
\end{tabular}




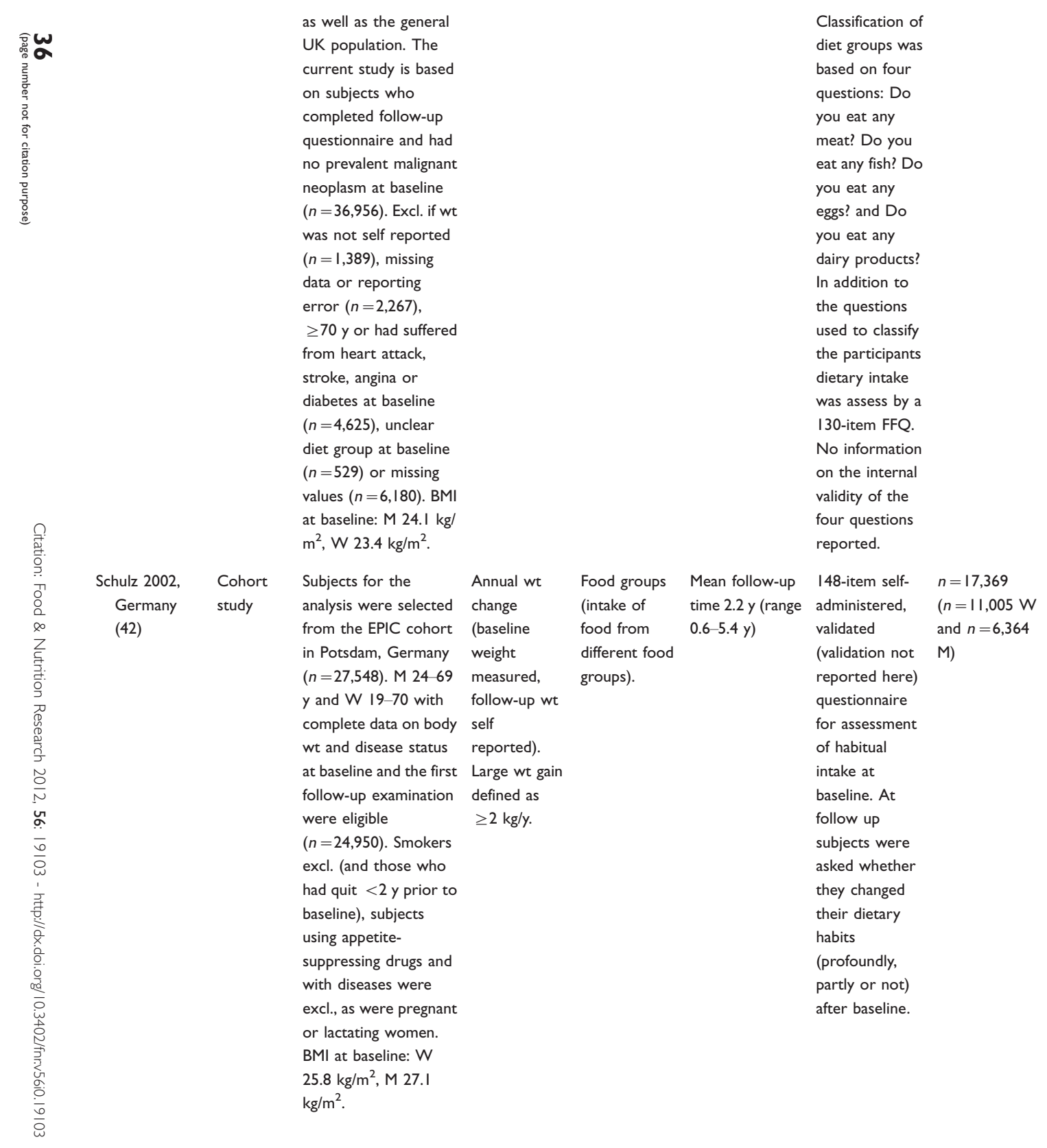

compared with

meat eaters (406,

$95 \%$ Cl: 373,439

and $423,95 \% \mathrm{Cl}$ :

403, 443, in $M$ and

$W$, respectively).

Fish eaters (W

only) had also

lower annual wt

gain $(338 \mathrm{~g}, 95 \%$

Cl: 300-376) than

meat eaters. age, ht, wt at

baseline.

vegans in

the study. Wt

self-reported.

\begin{tabular}{|c|c|c|c|}
\hline op out $30 \%$. & $\begin{array}{l}\text { Large wt gain } \\
(\geq 2 \mathrm{~kg} / \mathrm{y}) \text { was } \\
\text { predicted by } \\
\text { consumption of } \\
\text { sweets. For each } \\
100 \mathrm{~g} / \text { day } \\
\text { increment in } \\
\text { sweets intake, the } \\
\text { likely hood of } \\
\text { observing a large } \\
\text { weight gain } \\
\text { increased by } 48 \% \\
\text { (OR I.48; } 95 \% \mathrm{Cl} \text { : } \\
\text { I.03, 2.13). In W } \\
\text { large wt gain was } \\
\text { predicted by } \\
\text { reported higher } \\
\text { fat, sauce and meat } \\
(\mathrm{OR} 1.75,95 \% \mathrm{Cl} \text { : } \\
\text { I.0I-3.06; OR } \\
2.12,95 \% \mathrm{Cl} \text { : } \\
\text { I.17-3.82 and OR } \\
\text { I.36, } 95 \% \mathrm{Cl} \text { : } \\
\text { I.04-I.79, } \\
\text { respectively). }\end{array}$ & $\begin{array}{l}\text { Age, initial body } \\
\text { wt and ht, } \\
\text { education, } \\
\text { weight history } \\
\text { (cycling, } \\
\text { previous wt } \\
\text { loss or gain), } \\
\text { medication, } \\
\text { menopausal } \\
\text { status, life and } \\
\text { health } \\
\text { contentment, } \\
\text { dietary change, } \\
\text { PA, prevalent } \\
\text { diabetes and } \\
\text { thyroid disease. }\end{array}$ & $\begin{array}{l}\text { B } \\
\text { Follow up } \\
\text { questionnaire } \\
\text { limited to } \\
\text { changes. Self } \\
\text { reported wt } \\
\text { at endpoint } \\
\text { but measured } \\
\text { at baseline. }\end{array}$ \\
\hline
\end{tabular}




\begin{tabular}{|c|c|c|c|c|c|c|c|c|c|c|c|}
\hline $\begin{array}{c}\text { Schulze 2004, } \\
\text { USA (43) }\end{array}$ & $\begin{array}{l}\text { Cohort } \\
\text { study }\end{array}$ & $\begin{array}{l}\text { Subjects from the } \\
\text { Nurses' Health Study II } \\
(n=|16,67|) \text {, female } \\
\text { US Nurses aged } 2444 \\
\text { y at study initiation } \\
\text { 1989. Excl. if they did } \\
\text { not complete relevant } \\
\text { dietary questions in } \\
\text { I991, had history of } \\
\text { diabetes or CVD } \\
\text { before } 1995 \text { or } \\
\text { reported diagnosis of } \\
\text { cancer, no report on } \\
\text { body wt or had no } \\
\text { data on PA. Baseline } \\
\text { BMI } 24.2-24.80 \mathrm{~kg} / \mathrm{m}^{2} \\
\text { across SSSD } \\
\text { consumption groups. }\end{array}$ & $\begin{array}{l}\text { Mean wt } \\
\text { changes from } \\
1991 \text { to } 1995 \\
\text { and from } \\
1995 \text { to } 1999 \\
\text { (self re- } \\
\text { ported) }\end{array}$ & SSSD & 4 and $8 y$ & $\begin{array}{l}\text { I33-item } \\
\text { validated semi } \\
\text { quantitative } \\
\text { FFQ. } \\
\text { Correlation } \\
\text { coefficients } \\
\text { between the } \\
\text { FFQ and } \\
\text { multiple dietary } \\
\text { records ranged } \\
\text { from } 0.36 \text { to } \\
0.89 \text {. See } \\
\text { original article } \\
\text { for the } \\
\text { literature } \\
\text { reference. }\end{array}$ & $n=51,603 \mathrm{~W}$ & $\begin{array}{l}\text { Drop out dur- } \\
\text { ing follow up } \\
66 \% \text { from the } \\
\text { original sample; } \\
\text { drop out dur- } \\
\text { ing follow up } \\
44 \% \text { of those } \\
\text { eligible after } \\
\text { excl. }\end{array}$ & $\begin{array}{l}W \text { who increased } \\
\text { their consumption } \\
\text { of SSSD from low } \\
\text { to high ( } \leq 1 / \text { week } \\
\text { to } \geq I / \text { day) had } \\
\text { significantly larger } \\
\text { increases in wt } \\
\text { (4.69 } \mathrm{kg} \text { (SE } 0.20 \\
\mathrm{~kg} \text { ) during } 1991- \\
1995 \text { and } 4.2 \mathrm{~kg} \text { (SE } \\
0.22 \mathrm{~kg} \text { ) during } \\
1995-1999 \text {, than } \\
W \text { who maintained } \\
\text { a low (3.2I kg SE } \\
0.03 \mathrm{~kg} \text { and } 2.04 \mathrm{~kg} \text {, } \\
\mathrm{SE} 0.03 \mathrm{~kg} \text { ) or a } \\
\text { high (3.I2 kg, SE } \\
0.13 \mathrm{~kg} \text { and } 2.21 \mathrm{~kg} \text {, } \\
\mathrm{SE} 0.13 \mathrm{~kg} \text { ) intake } \\
\text { or substantially } \\
\text { reduced their } \\
\text { intake (I.34 kg, SE } \\
0.07 \mathrm{~kg} \text { and } 0.15 \mathrm{~kg} \text {, } \\
\mathrm{SE} 0.18 \mathrm{~kg}) \text {, during } \\
\text { the two time } \\
\text { periods, } \\
\text { respectively. } \\
P<0.00 \text {. }\end{array}$ & $\begin{array}{l}\text { Baseline age, } \\
\text { alcohol intake, } \\
\text { PA, smoking, } \\
\text { postmenopau- } \\
\text { sal hormone } \\
\text { use, oral } \\
\text { contraceptive } \\
\text { use, total fat } \\
\text { intake and BMI. }\end{array}$ & $\begin{array}{l}\text { B } \\
\text { Drop-out } \\
\text { rate } \\
\text { exceeded } \\
20 \%\end{array}$ \\
\hline $\begin{array}{l}\text { Vergnaud 20।0, } \\
\text { Europé (44) }\end{array}$ & $\begin{array}{l}\text { Cohort } \\
\text { study }\end{array}$ & $\begin{array}{l}\text { EPIC (PANACEA), } \\
52 \mathrm{I}, 448 \text { apparently } \\
\text { healthy volunteers, } \\
25-70 \text { y from } 23 \\
\text { European centres. } \\
\text { Individuals with } \\
\text { missing information } \\
\text { excl., along with } \\
\text { subjects with } \\
\text { extreme values on } \\
\text { anthropometry, } \\
\text { pregnant women and } \\
\text { extreme El/ER. } \\
N=497,735 \text { available } \\
\text { for the baseline } \\
\text { analysis. BMI at } \\
\text { baseline: } \mathrm{W} 25 . \mathrm{l} \mathrm{kg} / \\
\mathrm{m}^{2}, \mathrm{M} 26.6 \mathrm{~kg} / \mathrm{m}^{2} .\end{array}$ & $\begin{array}{l}5 \text { y wt change } \\
\text { (follow-up } \\
\text { range 2-11 y). } \\
\text { Measured or } \\
\text { self reported } \\
\text { at baseline, } \\
\text { self reported } \\
\text { at endpoint. }\end{array}$ & $\begin{array}{l}\text { Meat } \\
\text { consumption } \\
\text { (red meat, } \\
\text { processed } \\
\text { meat and } \\
\text { poultry). }\end{array}$ & $\begin{array}{l}\text { Ranged from } 2 \\
\text { to } 11 \mathrm{y} \text {, adjusted } \\
\text { to } 5 \mathrm{y} \text {. }\end{array}$ & $\begin{array}{l}\text { Country } \\
\text { specific } \\
\text { validated } \\
\text { dietary } \\
\text { questionnaires } \\
\text { (validation not } \\
\text { reported here). } \\
\text { EPIC Nutrient } \\
\text { Database. } \\
\text { Dietary } \\
\text { calibration } \\
\text { study } \\
\text { completing an } \\
\text { additional 24-h } \\
\text { recall } \\
\text { (EPIC-SOFT). } \\
\text { See original } \\
\text { article for the } \\
\text { literature } \\
\text { reference. }\end{array}$ & $\begin{array}{l}n=373,803 \\
(n=103,455 \mathrm{M} \\
\text { and } \\
n=270,348 \mathrm{~W})\end{array}$ & Drop out $25 \%$. & $\begin{array}{l}\text { A } 100 \mathrm{kcal} / \mathrm{day} \\
\text { increase in meat } \\
\text { consumption was } \\
\text { associated with } 30 \\
\mathrm{~g}(95 \% \mathrm{Cl}: 24-36) \\
\text { annual increase in } \\
\text { wt. Significant for } \\
\text { all types of meat, } \\
\text { strongest } \\
\text { association found } \\
\text { for poultry. }\end{array}$ & $\begin{array}{l}\text { Sex, age, } \\
\text { indicator of } \\
\text { meat } \\
\text { consumption, } \\
\text { educational } \\
\text { level, PA, } \\
\text { smoking status, } \\
\text { initial BMI, } \\
\text { follow-up time, } \\
\text { total El, E from } \\
\text { alcohol, and } \\
\text { plausible total } \\
\text { El reporting. }\end{array}$ & $\begin{array}{l}\text { B } \\
\text { Sample not } \\
\text { intended to } \\
\text { be represen- } \\
\text { tative of each } \\
\text { region. Mixed } \\
\text { methods of } \\
\text { assessing wt } \\
\text { as well as } \\
\text { dietary intake. } \\
\text { Follow-up } \\
\text { period } \\
\text { different } \\
\text { between } \\
\text { centres. }\end{array}$ \\
\hline
\end{tabular}




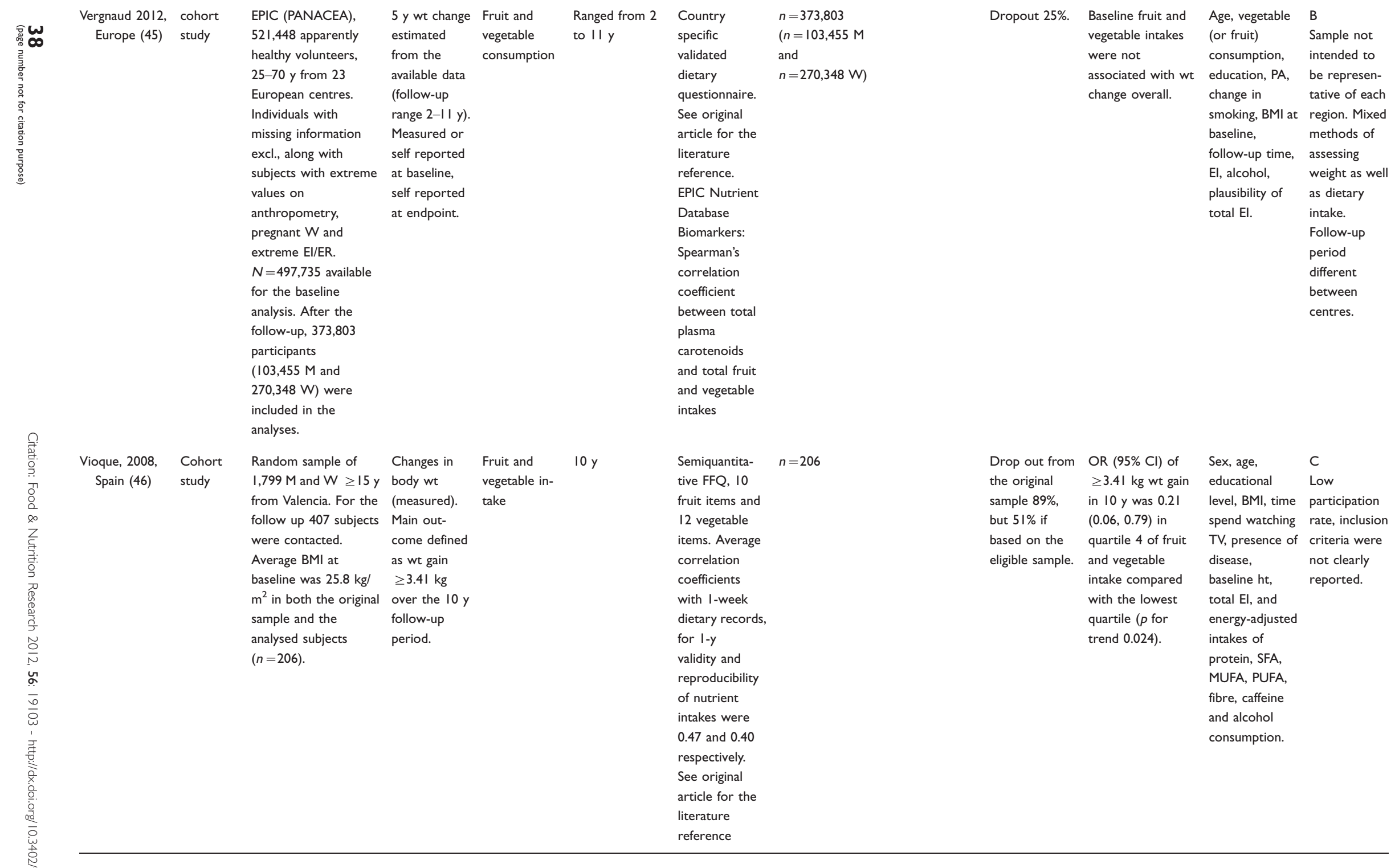

W, Women; M, Men; Wt, Weight; Ht, Height; WC, Waist circumference; PA, Physical activity; BMI, Body mass index; El, Energy intake; ED, Energy density; TFA, Trans fatty acids; CHO, Carbohydrates; MUFA, Monounsaturated fatty acids; PUFA, Poly-unsaturated fatty acids; GI, Glycemic index; GL, Glycemic load; Y, Years; SSSD, sugar-sweetened soft drink. 


\section{Appendix 5 \\ Evidence tables}

Table 3. Diets and prevention of weight gain

\begin{tabular}{|c|c|c|c|c|c|c|c|c|c|c|c|c|}
\hline $\begin{array}{l}\text { Reference } \\
\text { details, } \\
\text { First } \\
\text { author, } \\
\text { Year, } \\
\text { Country }\end{array}$ & $\begin{array}{l}\text { Study } \\
\text { design } \\
\text { (RCT, } \\
\text { CT, } \\
\text { cohort, } \\
\text { case } \\
\text { control } \\
\text { etc.) }\end{array}$ & $\begin{array}{l}\text { Population, subject } \\
\text { characteristics, } \\
\text { Inclusion/exclusion } \\
\text { criteria, setting, no at } \\
\text { baseline, } \\
\text { male/female, age, } \\
\text { ethnicity of the } \\
\text { subjects, } \\
\text { anthropometry, } \\
\text { location }\end{array}$ & $\begin{array}{l}\text { Outcome mea- } \\
\text { sures } \\
\text { Disease, } \\
\text { biological } \\
\text { measures }\end{array}$ & $\begin{array}{l}\text { Intervention/ } \\
\text { exposure }\end{array}$ & $\begin{array}{l}\text { Time } \\
\text { between } \\
\text { baseline } \\
\text { exposure and } \\
\text { outcome } \\
\text { assessment }\end{array}$ & $\begin{array}{l}\text { Dietary assess- } \\
\text { ment method } \\
\text { FFQ, food record } \\
\text { Internal } \\
\text { validation }(y / n)\end{array}$ & $\begin{array}{l}\text { No of subjects } \\
\text { analysed }\end{array}$ & $\begin{array}{l}\text { Intervention } \\
\text { (I) (dose } \\
\text { interval, } \\
\text { duration) } \\
\text { Control } \\
\text { (C) (active, } \\
\text { placebo, } \\
\text { usual care } \\
\text { etc), } \\
\text { compliance, } \\
\text { achieved } \\
\text { dietary } \\
\text { change, } \\
\text { adherence } \\
\text { to dietary } \\
\text { targets, } \\
\text { actual } \\
\text { dietary } \\
\text { change }\end{array}$ & $\begin{array}{l}\text { Follow-up } \\
\text { period, } \\
\text { drop-out rate } \\
\text { (from baseline } \\
\text { to follow-up, } \\
\text { or from end of } \\
\text { intervention } \\
\text { to follow-up) } \\
\text { Drop out (\%) }\end{array}$ & $\begin{array}{l}\text { Results (I, C) } \\
\text { (Absolute } \\
\text { difference, RR, OR, } \\
\text { - -value, confidence } \\
\text { interval, } \\
\text { sensitivity, } \\
\text { specificity, } \\
\text { observer } \\
\text { reliability? etc) }\end{array}$ & $\begin{array}{l}\text { Confounders } \\
\text { adjusted for }\end{array}$ & $\begin{array}{l}\text { Study quality and } \\
\text { relevance, } \\
\text { Comments } \\
\text { (A-C) }\end{array}$ \\
\hline $\begin{array}{c}\text { Beunza 2010, } \\
\text { Spain (47) }\end{array}$ & Cohort & $\begin{array}{l}\text { University graduates } \\
\text { Excl. those who } \\
\text { reported total El } \\
\text { ( }<800 \text { or }>4,200 \\
\text { kcal/day for } \mathrm{M} \text { and } \\
<600 \text { or } 3,500 \mathrm{kcal} / \\
\text { day for W), preg- } \\
\text { nancy, CVD at base- } \\
\text { line, no wt data. } \\
\text { Baseline } n=15,339 \text {, } \\
\text { age } 38 \mathrm{y}, \mathrm{BMI} 24.0 \mathrm{~kg} / \\
\mathrm{m}^{2}\end{array}$ & $\begin{array}{l}\text { An increase in } \\
\text { body wt of at } \\
\text { least } 5 \mathrm{~kg} \\
\text { during follow- } \\
\text { up. Change in } \\
\text { body wt } \\
\text { during follow- } \\
\text { up, Incident } \\
\text { overweight/ } \\
\text { obesity }\end{array}$ & $\begin{array}{l}\text { Mediterranean } \\
\text { dietary Score } \\
\text { (MDS), range 0- } \\
\text { 9: positive items: } \\
\text { vegetables, fruit } \\
\text { and nuts, le- } \\
\text { gumes, MUFA: } \\
\text { SFA, moderate } \\
\text { alcohol con- } \\
\text { sumption, fish; } \\
\text { negative: meat } \\
\text { and poultry, } \\
\text { dairy. See origi- } \\
\text { nal article for } \\
\text { reference. }\end{array}$ & $\begin{array}{l}\text { Mean } 5.7 y \\
\text { (median } \\
6.2 y \text { ) }\end{array}$ & $\begin{array}{l}\text { Semiquantitative } \\
\text { I36-item FFQ. } \\
\text { Validated, see } \\
\text { original article for } \\
\text { the literature } \\
\text { reference }\end{array}$ & $n=10,376$ & & $\begin{array}{l}\text { Mean } 5.7 \text { y. } \\
\text { Drop out } \\
\text { (did not } \\
\text { participate in } \\
\text { follow-up) was } \\
8 \% \text {, but a } \\
\text { further } 24 \% \\
\text { were excl. due } \\
\text { to missing } \\
\text { information } \\
\text { etc. }\end{array}$ & $\begin{array}{l}\text { Participants with } \\
\text { the lowest } \\
\text { adherence ( } \leq 3 \\
\text { points) to MDS had } \\
\text { the highest average } \\
\text { yearly wt gain, } \\
\text { whereas partici- } \\
\text { pants with the } \\
\text { highest } \\
\text { ( } \geq 6 \text { points) } \\
\text { adherence } \\
\text { exhibited the low- } \\
\text { est wt gain } \\
\text { (adjusted differ- } \\
\text { ence: }-0.059 \mathrm{~kg} / \mathrm{y} \text {; } \\
95 \% \mathrm{Cl}: 0.008 \mathrm{~kg} / \mathrm{y} ; \\
\text { p for trend }=0.02 \text { ). }\end{array}$ & $\begin{array}{l}\text { Sex, age, baseline } \\
\text { BMI, PA, sedentary } \\
\text { behaviour, smoking, } \\
\text { snacking, total El. }\end{array}$ & $\begin{array}{l}\text { B } \\
\text { Wt self- } \\
\text { reported. The } \\
\text { comparability of } \\
\text { this population } \\
\text { (students from } \\
\text { Spain) and } \\
\text { Nordic } \\
\text { population is not } \\
\text { clear. }\end{array}$ \\
\hline
\end{tabular}




\begin{tabular}{|c|c|c|c|c|c|c|c|c|}
\hline 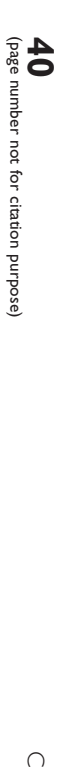 & $\begin{array}{l}\text { Quatromoni, } \\
\text { 2006, US } \\
(48)\end{array}$ & Cohort & $\begin{array}{l}\text { The Framingham } \\
\text { Offspring cohort, } \\
\text { baseline at } \\
\text { examination } 3 \\
\text { (1984-1988) } \\
n=3,873 \text { of whom } 2 / \\
3 \text { contributed dietary } \\
\text { data, incl. those who } \\
\text { contributed one or } \\
\text { two } 8-y \text { follow-up } \\
\text { periods ( } n=2,245 \text { ), } \\
\text { excl. cancer; average } \\
\text { age, } 49-56 \text { y) } \\
\text { ethnicity not } \\
\text { reported. Baseline } \\
\text { mean BMI varied } \\
\text { from } 26.9 \text { to } 27.4 \text { in } \\
\text { men, and from } 25.1 \\
\text { to } 25.8 \text { in women, } \\
\text { according to } \\
\text { different groups } \\
\text { of DQI. }\end{array}$ & $\begin{array}{l}8 \text { y wt change, } \\
\text { body wt } \\
\text { measured }\end{array}$ & $\begin{array}{l}\text { A five-point } \\
\text { dietary quality } \\
\text { index (DQI): Fat } \\
\text { intake }<30 \mathrm{E} \% \text {, } \\
\text { SAFA }<10 \mathrm{E} \% \text {, } \\
\text { chol }<300 \mathrm{mg} / \\
\text { day, sodium } \\
<2,400 \mathrm{mg} / \text { day, } \\
\text { CHO }>50 \mathrm{E} \%\end{array}$ & $\begin{array}{l}8 \text { y (from } \\
\text { examination } \\
3 \text { to } \\
\text { examination } \\
7, \text { which } \\
\text { took place in } \\
1998-2001 \text { ) }\end{array}$ & $\begin{array}{l}\text { 3-day dietary } \\
\text { records at exam } 3 \\
\text { (1984-1988) and } \\
\text { exam } 5 \text { (199|- } \\
\text { 1996). Minnesota } \\
\text { Nutrition Data } \\
\text { System software } \\
\text { (NDS 2.6) }\end{array}$ & $\begin{array}{l}n=990 \mathrm{M} \text { and } \\
n=1,255 \mathrm{~W} \\
(1,847 \\
\text { female and } \\
1,433 \text { male } \\
\text { observations, } \\
\text { since most } \\
\text { participant } \\
\text { were assessed } \\
\text { twice) }\end{array}$ \\
\hline 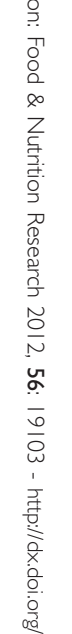 & $\begin{array}{l}\text { Romaguera, } \\
2010, \\
\text { Europé } \\
(49)\end{array}$ & $\begin{array}{l}\text { Cohort } \\
\text { study }\end{array}$ & $\begin{array}{l}\text { EPIC (PANACEA), } \\
n=521,448 \\
\text { apparently healthy } \\
\text { volunteers, } 25-70 \text { y } \\
\text { from } 23 \text { European } \\
\text { centres. Individuals } \\
\text { with missing } \\
\text { information excl., } \\
\text { along with subjects } \\
\text { with extreme values } \\
\text { on anthropometry, } \\
\text { pregnant women and } \\
\text { extreme El/ER. Thus } \\
n=497,735 \\
\text { available for the } \\
\text { baseline analysis. } \\
\text { Baseline BMI not } \\
\text { reported. }\end{array}$ & $\begin{array}{l}5 y \text { wt change } \\
\text { estimated from } \\
\text { the } \\
\text { available data } \\
\text { (follow-up } \\
\text { range 2-II y). } \\
\text { Measured or } \\
\text { self reported at } \\
\text { baseline, self } \\
\text { reported at } \\
\text { endpoint. }\end{array}$ & $\begin{array}{l}\text { Adherence to } \\
\text { the Mediterra- } \\
\text { nean diet (MED). } \\
\text { Scores created } \\
\text { from } 0 \text { to } 18 .\end{array}$ & $\begin{array}{l}\text { Ranged from } \\
2 \text { to } 11 \mathrm{y} .\end{array}$ & $\begin{array}{l}\text { Country specific } \\
\text { validated dietary } \\
\text { questionnaires } \\
\text { (validation not } \\
\text { reported here) }\end{array}$ & $\begin{array}{l}n=373,803 \\
(n=103,455 \\
M \text { and } \\
n=270,348 \\
W)\end{array}$ \\
\hline
\end{tabular}

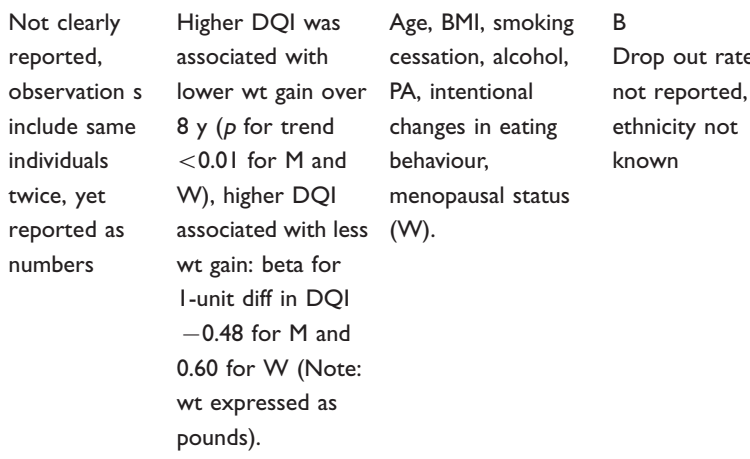

Dropout 25\%. Two point

increase in MED

predicted -0.05

$\mathrm{kg}(95 \% \mathrm{Cl}$ :

-0.07 to -0.02

$\mathrm{kg}$ ) less wt gain in 5

adherence (II-18

points) $-0.16 \mathrm{~kg}$

$(-0.24,-0.07 \mathrm{~kg})$

less wt gain in $5 y$

than people with

low

adherence

(0-6 points).

Protective effects

stronger in younger

and

non-obese.
Sex, age, baseline B

BMI, follow-up time, Sample not

ducational level, intended to be PA, smoking, representative menopausal status, of each region. Mixed methods misreporting of El. of assessing wt as well as dietary intake. Followup period different between centres. 


\begin{tabular}{|c|c|c|c|c|c|c|c|c|c|c|c|}
\hline $\begin{array}{l}\text { Sanchez- } \\
\text { Villegas } \\
2006, \\
\text { Spain (50) }\end{array}$ & Cohort & $\begin{array}{l}\text { Participants in the } \\
\text { SUN cohort study, } \\
\text { the recruitment } \\
\text { started in December } \\
1999 \text { (ongoing as a } \\
\text { dynamic cohort } \\
\text { study), for this study } \\
\text { participants followed } \\
>2 \text { y }(n=7,908 \text { ) } \\
\text { included, both M and } \\
W, \text { extremely low/ } \\
\text { high values for total } \\
\text { El and subjects with } \\
\text { missing values excl. }\end{array}$ & $\begin{array}{l}\text { Change in wt } \\
\text { and BMI. Wt } \\
\text { self-reported. }\end{array}$ & $\begin{array}{l}\text { Adherence to a } \\
\text { Mediterranean } \\
\text { dietary pattern } \\
\text { (MDP). }\end{array}$ & 28 months & $\begin{array}{l}\text { A validated semi } \\
\text { quantitative } \\
\text { I36-item FFQ. } \\
\text { Food composition } \\
\text { tables for Spain; } \\
\text { MDP defined by } \\
\text { scores according } \\
\text { to the tertile } \\
\text { distribution of } \\
\text { several compo- } \\
\text { nents of Mediter- } \\
\text { ranean diet. } \\
\text { For validation, see } \\
\text { original article for } \\
\text { the literature } \\
\text { reference. }\end{array}$ & $n=6,319$ & Drop out $20 \%$ & $\begin{array}{l}\text { Lowest baseline } \\
\text { MDP-scores } \\
\text { showed a higher wt } \\
\text { gain, but the in- } \\
\text { verse association } \\
\text { did not remain sig- } \\
\text { nificant after } \\
\text { adjusting for } \\
\text { confounders, } \\
\text { higher meat } \\
\text { consumption at } \\
\text { baseline associated } \\
\text { with greater wt } \\
\text { gain ( } 0.41 \text { kg vs. } \\
0.85 \mathrm{~kg} \text { in lowest } \\
\text { vs. highest third), } \\
\text { higher } \\
\text { consumption of } \\
\text { whole-fat dairy } \\
\text { products assoc. } \\
\text { with lower wt gain } \\
\text { ( } 0.64 \text { vs. } 0.28 \mathrm{~kg} \text { in } \\
\text { lowest vs. highest } \\
\text { third). }\end{array}$ & $\begin{array}{l}\text { Age, sex, baseline } \\
\text { BMI, PA during } \\
\text { leisure time, } \\
\text { smoking, alcohol, El, } \\
\text { change in dietary } \\
\text { habits and change } \\
\text { in PA. }\end{array}$ & $\begin{array}{l}\text { B } \\
\text { Based on } \\
\text { self-reported } \\
\text { weight }\end{array}$ \\
\hline $\begin{array}{l}\text { Zamora, } \\
\text { 20I0, USA } \\
\text { (5I) }\end{array}$ & $\begin{array}{l}\text { Cohort } \\
\text { study }\end{array}$ & $\begin{array}{l}\text { Subjects from the } \\
\text { CARDIA study } \\
(n=5,1 \mathrm{I} 5) \text {, } \\
\text { Birmingham AL; } \\
\text { Chicago IL; } \\
\text { Minneapolis MN; and } \\
\text { Oakland CA. Black } \\
(n=2,786) \text { and white } \\
(n=2,427) \text { M (47\%) } \\
\text { and W, 18-30 y at } \\
\text { baseline. Baseline } \\
\text { BMI } 23.7 \mathrm{~kg} / \mathrm{m}^{2} \\
\text { (whites). Eligibility } \\
\text { criteria, freedom } \\
\text { from chronic disease } \\
\text { or disability. }\end{array}$ & $\begin{array}{l}\text { Wt gain, } 10 \mathrm{~kg} \\
\text { wt gain } \\
\text { (measured) }\end{array}$ & $\begin{array}{l}\text { Diet Quality } \\
\text { Index (DQI) as } \\
\text { an estimate of } \\
\text { adherence to } \\
\text { the Dietary } \\
\text { Guidelines for } \\
\text { Americans. } \\
\text { Three categories } \\
\text { created, low, } \\
\text { medium and high } \\
\text { diet quality. }\end{array}$ & 7 and $20 y$ & $\begin{array}{l}\text { Interview- } \\
\text { administered } \\
\text { questionnaire } \\
\text { regarding usual } \\
\text { dietary practices } \\
\text { and a validated } \\
\text { quantitative } \\
\text { diet-history } \\
\text { questionnaire that } \\
\text { assessed } \\
\text { consumption of } \\
\text { foods over the } \\
\text { past month. }\end{array}$ & $\begin{array}{l}n=4,913 \\
(n=2,427 \\
\text { white) at } \\
\text { baseline and } \\
n=3,739 \\
(n=2,014 \\
\text { white) at } 7 \text { y }\end{array}$ & $\begin{array}{l}\text { Drop out } 19 \% \\
\text { at } 7 y \text { and } 28 \% \\
\text { at } 20 y .\end{array}$ & $\begin{array}{l}\text { High diet quality } \\
\text { associated with } \\
\text { significantly less wt } \\
\text { gain than low diet } \\
\text { quality (II.2 vs. } \\
\text { 13.9). Overall } \\
\text { (black and white) } \\
\text { HR for risk of } 10 \mathrm{~kg} \\
\text { wt gain was } 0.75 \\
\text { (95\% CI: } 0.65-0.87 \text { ) } \\
\text { for high DQI com- } \\
\text { pared with low } \\
\text { DQI. }\end{array}$ & $\begin{array}{l}\text { PA, El, smoking, } \\
\text { sociodemographic } \\
\text { characteristics. }\end{array}$ & $\begin{array}{l}\text { The number of } \\
\text { white subjects } \\
\text { included in the } \\
20 \text { y follow up is } \\
\text { missing. }\end{array}$ \\
\hline
\end{tabular}

W, Women; M, Men; Wt, Weight; Ht, Height; WC, Waist circumference; PA, Physical activity; BMI, Body mass index; El, Energy intake; ED, Energy density; TFA, Trans fatty acids; CHO, Carbohydrates; MUFA, Monounsaturated fatty acids; PUFA, Poly-unsaturated fatty acids; GI, Glycemic index; GL, Glycemic load; Y, Years. 


\section{Appendix 6}

Table 4. Prevention of weight regain after prior weight reduction

\begin{tabular}{|c|c|c|c|c|c|c|c|c|c|c|c|c|}
\hline $\begin{array}{l}\text { Reference } \\
\text { details, } \\
\text { First } \\
\text { author, } \\
\text { Year, } \\
\text { Country }\end{array}$ & $\begin{array}{l}\text { Study } \\
\text { design } \\
\text { (RCT, } \\
\mathrm{CT}, \\
\text { cohort, } \\
\text { case } \\
\text { control } \\
\text { etc.) }\end{array}$ & $\begin{array}{l}\text { Population, subject } \\
\text { characteristics, } \\
\text { Inclusion/exclusion } \\
\text { criteria, Setting, No } \\
\text { at baseline, Male/ } \\
\text { Female, Age, } \\
\text { Ethnicity of the } \\
\text { subjects, } \\
\text { Anthropometry, } \\
\text { Location }\end{array}$ & $\begin{array}{l}\text { Outcome } \\
\text { measures } \\
\text { Disease, } \\
\text { biological } \\
\text { measures }\end{array}$ & $\begin{array}{l}\text { Intervention/ } \\
\text { exposure }\end{array}$ & $\begin{array}{l}\text { Time be- } \\
\text { tween base- } \\
\text { line } \\
\text { exposure and } \\
\text { outcome } \\
\text { assessment }\end{array}$ & $\begin{array}{l}\text { Dietary } \\
\text { assessment } \\
\text { method FFQ, } \\
\text { food record In- } \\
\text { ternal validation } \\
(\mathrm{y} / \mathrm{n})\end{array}$ & $\begin{array}{l}\text { No of } \\
\text { subjects } \\
\text { analysed }\end{array}$ & $\begin{array}{l}\text { Intervention (I) } \\
\text { (dose interval, } \\
\text { duration) } \\
\text { Control (C) } \\
\text { (active, placebo, } \\
\text { usual care etc), } \\
\text { compliance, } \\
\text { achieved dietary } \\
\text { change, } \\
\text { adherence to diet- } \\
\text { ary targets, actual } \\
\text { dietary change }\end{array}$ & $\begin{array}{l}\text { Follow-up } \\
\text { period, } \\
\text { drop-out rate } \\
\text { (from baseline } \\
\text { to follow-up, } \\
\text { or from end of } \\
\text { intervention to } \\
\text { follow-up) } \\
\text { Drop out (\%) }\end{array}$ & $\begin{array}{l}\text { Results (I, C) } \\
\text { (Absolute } \\
\text { difference, RR, } \\
\text { OR, } p \text {-value, con- } \\
\text { fidence } \\
\text { interval, } \\
\text { sensitivity, } \\
\text { specificity, } \\
\text { observer } \\
\text { reliability? Etc.) }\end{array}$ & $\begin{array}{l}\text { Confounders } \\
\text { adjusted for }\end{array}$ & $\begin{array}{l}\text { Study quality and } \\
\text { relevance, } \\
\text { Comments (A-C) }\end{array}$ \\
\hline $\begin{array}{l}\text { Brinkworth, } \\
\text { 2004, } \\
\text { Australia } \\
(52)\end{array}$ & RCT & $\begin{array}{l}\text { Incl: BMI } 27-40 \mathrm{~kg} / \\
\mathrm{m}^{2} \text {, Type } 2 \text { diabetes. } \\
\text { Excl: proteinuria, } \\
\text { liver disease, CVD, } \\
\text { gastrointestinal } \\
\text { disease of a } \\
\text { malignancy. Setting: } \\
\text { outpatients. } \\
\text { Baseline: low- } \\
\text { protein (LP): } n=31 \text {, } \\
\text { high-protein (HP): } \\
n=33 \text { Age } 62 \text { y } \\
\text { (SD } 2 \text { y). Caucasian. } \\
\text { Body composition } \\
\text { by DXA. }\end{array}$ & $\begin{array}{l}\text { Wt, fat-free } \\
\text { mass, fat } \\
\text { mass (DXA) }\end{array}$ & $\begin{array}{l}\text { HP vs. LP diet for } \\
12 \text { weeks }+52 \\
\text { weeks follow-up. } \\
\text { Ad lib energy } \\
\text { intake. }\end{array}$ & $\begin{array}{l}12+52 \\
\text { weeks follow- } \\
\text { up. Only the } \\
\text { changes } \\
\text { during follow- } \\
\text { up are as- } \\
\text { sessed here. }\end{array}$ & $\begin{array}{l}\text { Not reported. } \\
\text { Biomarker assay: } \\
24 \text { h urinary urea/ } \\
\text { creatinine }\end{array}$ & $\begin{array}{l}\text { LP: } n=19 \\
n=7 \mathrm{M}, \\
n=12 \mathrm{~W}) ; \\
\text { HP } n=19 \\
(n=8 \mathrm{M}, \\
n=11 \mathrm{~W}) .\end{array}$ & $\begin{array}{l}\text { LP-diet: } 15 \% \\
\text { protein, } 55 \% \text { CHO, } \\
30 \% \text { fat. HP-diet: } \\
30 \% \text { protein, } 40 \% \\
\mathrm{CHO}, 30 \% \text { fat. The } \\
\text { diets were super- } \\
\text { vised for } 12 \text { weeks. } \\
\text { No measurement } \\
\text { of dietary intake. }\end{array}$ & $\begin{array}{l}\text { Follow-up: } 52 \\
\text { weeks. } \\
\text { Drop out } 39 \% \\
\text { in LP } 42 \% \text { in } \\
\text { HP. }\end{array}$ & $\begin{array}{l}\text { Initial wt loss in } \\
\text { both groups was } \\
5.3 \mathrm{~kg} \text {. Wt gain } \\
\text { during follow-up: } \\
\text { LP: } 3.3 \mathrm{~kg} \text {; HP: } 1.5 \\
\mathrm{~kg} \text {. Difference ns } \\
(p>0.05) \text {. Same } \\
\text { result for FFM and } \\
\text { FM. }\end{array}$ & $\begin{array}{l}\text { No adjustment. } \\
\text { ANOVA used } \\
\text { for statistical } \\
\text { comparison. }\end{array}$ & $\begin{array}{l}\text { B } \\
\text { Small sample size, } \\
\text { change of outcomes } \\
\text { were not presented, } \\
\text { although statistically } \\
\text { analysed, no markers } \\
\text { of dietary exposure. } \\
\text { Note that LP-diet was } \\
\text { close to normal } \\
\text { dietary } \\
\text { recommendations. } \\
\text { HP-diet was also a } \\
\text { moderately low- } \\
\text { CHO-diet. }\end{array}$ \\
\hline $\begin{array}{l}\text { Dale, 2009, } \\
\text { New } \\
\text { Zealand } \\
(53)\end{array}$ & RCT & $\begin{array}{l}\text { Incl: } W \text { who had lost } \\
>5 \% \text { body wt in the } \\
\text { previous } 6 \text { months. } \\
\text { Excl: chronic } \\
\text { physical or } \\
\text { psychiatric illness } \\
\text { (e.g. diabetes, CVD, } \\
\text { etc.), medications } \\
\text { which affect wt, }\end{array}$ & $\begin{array}{l}\text { Wt, fat-free } \\
\text { mass, fat } \\
\text { mass (by } \\
\text { BIA) }\end{array}$ & $\begin{array}{l}2 \times 2 \text { factorial } \\
\text { design: support- } \\
\text { ing program: in- } \\
\text { tensive or nurse; } \\
\text { diet: high-MUFA } \\
\text { or high-CHO. } \\
\text { Ad lib energy } \\
\text { intake. }\end{array}$ & $\begin{array}{l}104 \text { months } \\
(2 \mathrm{y}) .\end{array}$ & 3-day diet record. & $\begin{array}{l}200 \text { (in } \\
\text { Intension- } \\
\text { to-treat } \\
\text { analysis). }\end{array}$ & $\begin{array}{l}\text { High-MUFA: } \mathrm{CHO} \\
42 \% \text {, } \\
\text { protein } 21 \% \text {, fat } \\
32 \% \text {; High-CHO: } \\
\text { CHO } 47 \% \text {, } \\
\text { protein } 19 \% \text {, fat } \\
30 \% \text {. }\end{array}$ & $\begin{array}{l}n=174(87 \%) \\
\text { were followed } \\
\text { for } 2 y .\end{array}$ & $\begin{array}{l}\text { Difference } \\
\text { between the diet- } \\
\text { groups in change } \\
\text { from baseline to } 2 \\
y \text { : Wt } 0.7 \mathrm{~kg}(95 \% \\
\mathrm{Cl}:-1.1 \text { to } 2.4), \\
\text { fat mass } 0.4 \mathrm{~kg} \\
(95 \% \mathrm{Cl}-0.3 \text { to } \\
\text { l. } 1) \text {. }\end{array}$ & $\begin{array}{l}\text { Mixed analytical } \\
\text { models } \\
\text { accounting, e.g. } \\
\text { baseline values. } \\
\text { The models } \\
\text { included terms, } \\
\text { e.g. support } \\
\text { program etc. }\end{array}$ & $\begin{array}{l}\text { B } \\
\text { Statistical power } \\
\text { calculation not } \\
\text { reported, however } \\
\text { the size seemed } \\
\text { adequate; dietary } \\
\text { assessment } \\
\text { database not } \\
\text { reported. }\end{array}$ \\
\hline
\end{tabular}

at baseline, age $45 \mathrm{y}$

(SD 10 y) $.91 \%$ white 


\begin{tabular}{|c|c|c|c|c|c|c|c|c|c|c|c|c|}
\hline $\begin{array}{l}\text { Delbridge } \\
\text { 2009; } \\
\text { Australia } \\
\text { (59) }\end{array}$ & RCT & $\begin{array}{l}\text { Incl.: Age } 18-75 \mathrm{y}, \\
\mathrm{BMI}>30 \text { or }>27 \\
\mathrm{~kg} / \mathrm{m}^{2}+ \\
\text { co-morbidities. } \\
\text { Excl.: Several } \\
\text { diseases, alcohol and } \\
\text { drug abuse, } \\
\text { lactation, pregnancy. } \\
n=179 \text { at baseline, } \\
n=141 \text { randomised, } \\
\text { mean age } 44 \mathrm{y}, \\
\text { (SD } 3 \text { y). }\end{array}$ & $\begin{array}{l}\text { Wt, waist } \\
\text { WC, body } \\
\text { composition } \\
\text { (BIA) }\end{array}$ & $\begin{array}{l}\text { Wt-loss diet for } \\
3 \text { months, fol- } \\
\text { lowed by } 12 \\
\text { months RCT } \\
\text { (high- } \\
\text { protein, HP, } \\
\text { or high- } \\
\text { carbohydrate, } \\
\text { HC, diets). Aim } \\
\text { for energy intake } \\
\text { during weight } \\
\text { maintenance: } \\
\text { I.3 } \times \text { estimated } \\
\text { resting energy } \\
\text { expenditure }\end{array}$ & $\begin{array}{l}3+12 \\
\text { months wt- } \\
\text { maintenance } \\
\text { intervention. } \\
\text { Only the } \\
\text { changes } \\
\text { during } \\
\text { intervention } \\
\text { are assessed } \\
\text { here. }\end{array}$ & $\begin{array}{l}3 \text { days food } \\
\text { records, internal } \\
\text { validation by } 24 \mathrm{~h} \\
\text { urine urea } \\
\text { excretion. } \\
\text { Foodworks } \\
\text { Professional } \\
\text { Edition version } \\
3.02 .58 \text { I }\end{array}$ & $\begin{array}{l}\mathrm{HP} n=71 \\
\mathrm{HC} n=70\end{array}$ & $\begin{array}{l}\text { HP: Protein } 30 \mathrm{E} \% \text {, } \\
\text { fat <30 E\%, CHO } \\
>40 \% \text {. HC: Pro- } \\
\text { tein } 15 \% \text {, fat }< \\
30 \% \text {, CHO }>55 \% .\end{array}$ & $\begin{array}{l}n=82 \\
\text { completed the } \\
\text { RCT. Drop out } \\
40 \% .\end{array}$ & $\begin{array}{l}\text { Wt loss during } \\
\text { phase I ( } 3 \\
\text { months) was I } 6.5 \\
\text { kg (ns } \\
\text { between HP vs. } \\
\text { HC). Change dur- } \\
\text { ing RCT: HP: wt } \\
+3.0 \mathrm{~kg} \text {, FM + } \\
4.2 \mathrm{~kg} \text {; HC: wt + } \\
4.3 \mathrm{~kg} \text {, FM: } \\
+3.2 \mathrm{~kg} \text {; ns for all } \\
\text { measured vari- } \\
\text { ables; results not } \\
\text { different for com- } \\
\text { pleters only or by } \\
\text { ITT analysis). }\end{array}$ & No adjustments. & $\begin{array}{l}\text { A } \\
\text { Only concern: } \\
\text { statistical power } \\
\text { calculation not } \\
\text { reported, however } \\
\text { the size seemed } \\
\text { adequate. }\end{array}$ \\
\hline $\begin{array}{l}\text { Due, 2008; } \\
\text { Denmark } \\
\text { (54) }\end{array}$ & RCT & $\begin{array}{l}\text { Incl.: } 18-35 \text { y, BMI } \\
28-36 \mathrm{~kg} / \mathrm{m}^{2} \text {, lost wt } \\
>8 \% \text { during phase I } \\
\text { (more details in } \\
\text { another paper). } \\
n=131 \text { randomised, } \\
\text { age } 28 \text { y(SD } 5 \text { y). }\end{array}$ & $\begin{array}{l}\text { Wt and body } \\
\text { composition } \\
\text { by DXA. }\end{array}$ & $\begin{array}{l}\text { Wt-loss diet for } \\
8 \text { weeks, fol- } \\
\text { lowed by } 6 \\
\text { months } \\
\text { RCT:MUFA-diet, } \\
\text { low-fat diet (LF), } \\
\text { or control -diet } \\
\text { (C):. Ad lib en- } \\
\text { ergy intake. }\end{array}$ & $\begin{array}{l}2+6 \\
\text { months wt- } \\
\text { maintenance } \\
\text { intervention. } \\
\text { Only the } \\
\text { changes } \\
\text { during } \\
\text { intervention } \\
\text { are assessed } \\
\text { here. }\end{array}$ & $\begin{array}{l}\text { Supermarket } \\
\text { model: all foods } \\
\text { were collected at } \\
\text { a 'supermarket' } \\
\text { established at the } \\
\text { department. The } \\
\text { nutrient contents } \\
\text { were analysed } \\
\text { from a database. } \\
\text { Compliance } \\
\text { assessed by fatty } \\
\text { acid analyses, } \\
\text { biopsy from } \\
\text { subcutaneous } \\
\text { adipose tissue at } \\
\text { screening and } 6 \\
\text { months. } \\
\text { Biomarkers: fat } \\
\text { biopsy (fatty acid } \\
\text { composition) }\end{array}$ & $\begin{array}{l}\text { MUFA: } \\
n=52 ; \text { LF: } \\
n=47 ; \text { C: } \\
n=25\end{array}$ & $\begin{array}{l}\text { Actual E\% in each } \\
\text { diet: } \\
\text { MUFA-diet: Fat } \\
\text { 38\%, SFA 7\%, } \\
\text { MUFA } 20 \% \text {, PUFA } \\
8 \% \text {, CHO } 43 \% \text {, } \\
\text { protein } 15 \% \text {. LF- } \\
\text { diet: Fat } 24 \% \text {, SFA } \\
8 \% \text {, MUFA } 8 \% \text {, } \\
\text { PUFA 5\%, CHO } \\
56 \% \text {, protein } 16 \% \text {. } \\
\text { C-diet: Fat } 32 \% \text {, } \\
\text { SFA I5\%, MUFA } \\
10 \% \text {, PUFA } 4 \% \text {, } \\
\text { CHO 50\%, protein } \\
16 \% \text {. }\end{array}$ & $\begin{array}{l}n=106 \\
\text { completed the } \\
\text { RCT. Drop out } \\
15 \%\end{array}$ & $\begin{array}{l}\text { Wt regains: } \\
\text { MUFA } 2.5 \mathrm{~kg}, \mathrm{LF} \\
2.2 \mathrm{~kg}, \text { CON } 3.8 \\
\mathrm{~kg} \text { (ns). Regain in } \\
\text { FM: MUFA } 2.2 \mathrm{~kg} \text {, } \\
\text { LF } 1.3 \mathrm{~kg}, \text { C } 3.5 \\
\mathrm{~kg} \text {. Differences } \\
\text { (95\% Cl): MUFA } \\
\text { vs. C: } 1.9 \text { (0.1- } \\
3.7) \mathrm{kg}, \text { LF vs. C: } \\
2.5 \text { (0.7-4.4 kg), } \\
\text { MUFA vs. LF: } 0.7 \\
\text { (-0.9 to } \\
-2.2 . \text { kg. }\end{array}$ & No adjustments. & A \\
\hline $\begin{array}{l}\text { Field, } 200 \mathrm{I} \\
\text { USA (6I) }\end{array}$ & $\begin{array}{l}\text { Cohort } \\
\text { study }\end{array}$ & $\begin{array}{l}\text { Incl.: W, participant } \\
\text { in nurses' health } \\
\text { study; excl.: numer- } \\
\text { ous criteria related } \\
\text { to pregnancy, health } \\
\text { status, PA etc. } n= \\
47,515 \text { at baseline } \\
\text { (1989), age } 25-43 \text { y. } \\
\text { Wt maintenance } \\
\text { analyses were }\end{array}$ & 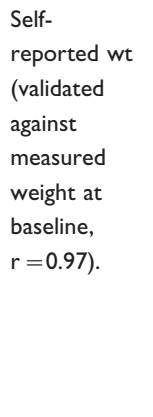 & & $\begin{array}{l}\text { Wt change } \\
\text { 1989-1991, } \\
\text { weight-loss } \\
\text { maintenance } \\
\text { 1991-1995 }\end{array}$ & $\begin{array}{l}\text { II6-item FFQ, } \\
\text { validated } \\
\text { previously, see } \\
\text { original article for } \\
\text { reference. }\end{array}$ & $\begin{array}{l}n=3,916 \\
W \text { who } \\
\text { had lost wt } \\
\text { at least } 5 \% \\
\text { between } \\
1989 \text { and } \\
1991 .\end{array}$ & & No data & $\begin{array}{l}\text { Fat E\% was not } \\
\text { associated with } \\
\text { wt change. There } \\
\text { was a modest } \\
\text { positive } \\
\text { association } \\
\text { between protein } \\
\text { E\% and weight } \\
\text { gain. }\end{array}$ & $\begin{array}{l}\text { Age, smoking, } \\
\text { PA, wt cycling } \\
\text { history, El, BMI } \\
\text { at age I8, wt } \\
\text { change } \\
\text { between age } 18 \\
\text { and y 1989, wt } \\
\text { change between } \\
1989 \text { and } 1991\end{array}$ & $\begin{array}{l}\text { C } \\
\text { Dietary data were not } \\
\text { reported in details, } \\
\text { e.g. no indication } \\
\text { whether the data } \\
\text { were Edjusted, only } \\
\text { small number of the } \\
\text { original cohort } \\
\text { included in the analy- } \\
\text { sis, dietary intake as- } \\
\text { sessed only once, self- } \\
\text { reported wt. }\end{array}$ \\
\hline
\end{tabular}




\begin{tabular}{|c|c|c|}
\hline $\begin{array}{l}\text { Swinburn, } \\
\text { 200I, } \\
\text { New } \\
\text { Zealand } \\
(57)\end{array}$ & RCT & $\begin{array}{l}\text { Incl.: Adults with } \\
\text { impaired glucose } \\
\text { tolerance or } \\
\text { otherwise abnormal } \\
\text { B-glucose, but not } \\
\text { type } 2 \text { diabetes. At } \\
\text { baseline } n=176 \\
\text { (sex-distribution not } \\
\text { reported) and at I y } \\
n=136(n=10 \text { I M, } \\
n=35 \mathrm{~W} \text {; European } \\
\text { race } 97 \text { (76\%), } \\
\text { Maori, pacific } \\
\text { Islanders and other } \\
24 \% \text {. Mean age } 52.5 \\
\text { y (RF) and } 52.0 \text { y } \\
\text { (control) }\end{array}$ \\
\hline
\end{tabular}

Wt, BMI

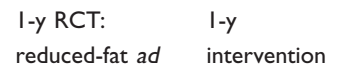

3-day food

$n=99$ at

reduced-fat ad intervention diary before

randomisation

2-y follow-

up, $n=103$

F diet at I $y$ : fat

follow-up

$26 \mathrm{E} \%, \mathrm{CHO} 55$

Us

follow-up for 4- $y$ (total study

New Zealand d

duration 5 y) base

(Nutritionist III

software)

E\%, protein $17 \mathrm{E} \%$. and at 4-y

follow-up $42 \%$.

$(\beta=0.10$,

$p=0.01$ ) or I-y

decrease in chol

$\mathrm{E} \%(\beta=-0.12$,

$p=0.0001$ ) or

exercise

$(\beta=-0.12$,

$p=0.000$ I) were

associated with

weight regain.

White, 2010, RCT

UK (58)

25 and $35 \mathrm{~kg} / \mathrm{m}^{2}$.

free from illness, not compos

on a specific diet or (BIA)

medication affecting

wt, no wt-reduction

for past 3 months,

intention to lose wt

$n=169, \mathrm{~W}$, age 37,

SD 1.3 y, Scottish

(Caucasian)

3-month

7-day unweighed $\quad n=126$

$n=126 \quad$ Composition for 6 months

intervention diets

at 3 months: GI:

$25 \%)$

protein $19 \mathrm{E} \%$,

$\mathrm{CHO} 5 \mathrm{I} \mathrm{E}$, fat 25

reduced $\mathrm{El}$ and together 9 months.

$\mathrm{E} \%$, sucrose $5 \mathrm{E} \%$

fat only; G3:

G2: Protein 18

reduction in $\mathrm{El}$ ),

followed by 6

months wt-

$\mathrm{E} \%, \mathrm{CHO} 50 \mathrm{E} \%$, fat

$27 \mathrm{E} \%$,

maintenance

follow-up.

2-y follow-up: RF: Age, sex,

-1.6 (SD 0.8) kg, ethnicity

Note: European race only $70 \%$ and results were not presented separately for these participants.

Change in body

wt during the

Not indicated

6-month

up: GI: $-0.1 \mathrm{~kg}$

(SD not

reported); G2: 0.0

(SD not

reported). Simi-

larly: body fat- $\%$

was unchanged

during follow-up

in all groups.
C

er short followup, no power calculations, randomisation not

explained, no

indications of comparability of the groups. results not adjusted for El, very low su-

crose intakes, lack of clear statistics for wt change. 